4 Colin N. Waters ${ }^{1}$ and Daniel J. Condon ${ }^{2}$

$5 \quad{ }^{1}$ British Geological Survey, Kingsley Dunham Centre, Keyworth, Nottingham, NG12 5GG

$6 \quad{ }^{2}$ NERC Isotope Geoscience Laboratory, British Geological Survey, Kingsley Dunham Centre,

7 Keyworth, Nottingham, NG12 5GG

\section{Nature and timing of Late Mississippian to Mid Pennsylvanian glacio-eustatic sea-level changes of the Pennine Basin, UK}

*E-mail: cnw@bgs.ac.uk

Abstract: The Pennine Basin of northern England contains a comparatively complete Serpukhovian-Moscovian succession characterised by high-resolution ammonoid zonation and cyclic paralic sedimentation. Two new ID-TIMS zircon ages from a bentonite deposited during the Arnsbergian (mid-Serpukhovian) regional substage and tonstein of earliest Bolsovian (early Moscovian) regional substage, have been determined. The weighted mean ${ }^{206} \mathrm{~Pb} /{ }^{238} \mathrm{U}$ ages of $328.34 \pm 0.55$ and $314.37 \pm 0.53 \mathrm{Ma}$ (total uncertainty), respectively, require modification of the timescale for the Western Europe regional chronostratigraphy.

The areal extent of acme ammonoid facies are used as a proxy for the magnitude of 47 discrete flooding events. Incised valleys (major sequence boundaries) are used as a proxy for the magnitude of sea-level falls. The frequency of these events, in the light of the new radiometric dating, indicates: (1) temporal coincidence between major glaciations in Gondwana and phases of increased frequency of sequence boundaries in the Pennine Basin; (2) high amplitude flooding surfaces have an average frequency of c. $400 \mathrm{ka}$; (3) average cycle durations during the Pendleian-early Arnsbergian and Chokierian-Bolsovian, of c.111 ka and c.150 ka, respectively, reflect short-duration eccentricities, and (4) multiple flooding surfaces with the same ammonoid assemblages may equate with sub-100 ka precession/obliquity frequencies.

Supplementary material: U-Pb method description and data, procedure for the calculation of the areal extent of marine bands and tables showing a full listing of biostratigraphical data used in the study are available at www.geolsoc.org.uk/SUPXXXXX. 
Limited data exists for constraining the Carboniferous timescale (Davydov et al. 2004), representing a major limitation of our understanding of biological and environmental change, their linkages, and the rates at which change occurred during that interval. The current timescale for the Carboniferous (Davydov et al. 2004, modified by Ogg et al. 2008) is largely derived from dating of international stages, defined by a conodont-based stratigraphy. However many parts of the world, including the equatorial paralic basins of Western Europe and eastern USA, and regions located close to a palaeopole (e.g. Australia) cannot successfully use this scheme due to the lack of suitable fauna. The development of truly global geological 'timescales' requires the calibration, via radio-isotopic dating, and integration, of several different biostratigraphical schemes.

During the Carboniferous-Permian 'icehouse' global scale climate oscillations occurred at varying timescales. The Gondwanan glacial record suggests a series of distinct and 'short-lived' (1-4 Ma) glacial episodes (Fielding et al. 2008) whereas the equatorial 'Laurussia' records both 'long' and 'short' climate fluctuation. Outstanding issues for understanding CarboniferousPermian environmental change include determination of the timing, duration and tempo of glaciation and the equatorial response to changes in polar regions.

This paper integrates bio- and litho-stratigraphic analyses of mid Carboniferous (Serpukhovian to Moscovian) strata of the Pennine Basin of central and northern England and North Wales (Fig. 1) combined with new $\mathrm{U}-\mathrm{Pb}$ dating with the overarching aim of developing an integrated biostratigraphic, geochronologic and palaeoenvironmental dataset. There are two specific aims: (1) the high-precision calibration of mid-Carboniferous biostratigraphic zonation for Western Europe; (2) assessment of cyclic marine bands in relationship to known orbital forcings via glacio-eustatic sea-level fluctuation.

Previous attempts at estimating the duration of Namurian and Westphalian cyclicity have assumed a constant forcing mechanism during the entire interval. In this study we investigate that premise and present evidence for variations in the magnitude of flooding and regressive events which aid determination of a cyclostratigraphy for the succession.

\section{Summary of existing radiometric dates}

Hess \& Lippolt (1986) and Berger et al. (1997) derived ${ }^{40} \mathrm{Ar} /{ }^{39} \mathrm{Ar}$ sanidine plateau dates from German and Czech tonsteins which suggested that the combined duration of the Namurian and Westphalian (broadly Serpukhovian to Moscovian) was about 21 Ma. The age determinations were largely for Stephanian, Bolsovian and early to mid Namurian tonsteins (Table 1) and provided no dates at the base of either the Namurian or Westphalian regional stages. 
Recalibration of the MMHb-1 mineral standard, summarised in Davydov et al. (2004) results in revised ages which approximate to determinations using U-Pb TIMS (Table 1). Hess \& Lippolt (1986) provided age uncertainties of 1.0 to $9.2 \mathrm{Ma}(2 \sigma)$; revised by Claoué-Long et al. (1995) to uncertainties of 7.4 to $10.0 \mathrm{Ma}(2 \sigma)$ based upon consideration of the uncertainties in the age of standard mineral against which the ${ }^{40} \mathrm{Ar} /{ }^{39} \mathrm{Ar}$ dates are calibrated. The limited biostratigraphical control in the German/Czech succession also limits the precise correlation of these dates globally.

${ }^{206} \mathrm{~Pb} /{ }^{238} \mathrm{U}$ zircon dates using the SHRIMP ion microprobe have provided Asbian (late Visean) dates of $334 \pm 4 \mathrm{Ma}(2 \sigma)$ from Poland (Kryza et al. 2010), Arnsbergian (early Namurian) dates of $314.5 \pm 4.6 \mathrm{Ma}(2 \sigma)$ for the Pennine Basin, UK (Riley et al. 1995), and Bolsovian (Westphalian) dates of $311.0 \pm 3.4 \mathrm{Ma}(2 \sigma)$ from Germany (Claoué-Long et al. 1995). These suggest a c. $3.5 \mathrm{Ma}$ duration for much of the Namurian and Westphalian, combined. The potential inaccuracies related to standardisation (Ireland \& Williams 2003), in addition to the reported uncertainties, for the U-Pb SHRIMP dates discussed above do not permit a precise duration of the intervals required for the advancement of Carboniferous stratigraphy.

The U-Pb SHRIMP dates are at odds with recent timescales (Davydov et al. 2004, modified by Ogg et al. 2008) and high precision ID-TIMS U-Pb zircon ages for the Donetz Basin (Davydov et al. 2010). The latter work provides errors of about $100 \mathrm{ka}$, of sufficient resolution to be useful in determining the duration of marine band cyclicity. However, ammonoids are rare in the Donetz Basin and the main biostratigraphical correlations are based on foraminiferal zones. Although correlation at the substage level between the Pennine and Donetz basins is established, it is not possible to directly correlate the ages with specific marine bands in the UK. The work of Davydov et al. (2010) is significant in that it provides a $328.14 \pm 0.11 \mathrm{Ma}$ age for the early-mid Pendleian and a $314.40 \pm 0.06 \mathrm{Ma}$ age for the early Bolsovian, more than $3 \mathrm{Ma}$ older than previous determinations using ${ }^{40} \mathrm{Ar} /{ }^{39} \mathrm{Ar}$ and ${ }^{206} \mathrm{~Pb} /{ }^{238} \mathrm{U}$ SHRIMP techniques (Table 1), most likely reflecting errors in the standardisation of both the ${ }^{40} \mathrm{Ar} /{ }^{39} \mathrm{Ar}$ and ${ }^{206} \mathrm{~Pb} /{ }^{238} \mathrm{U}$ SHRIMP dates. The Bolsovian would now appear to be in excess of $4 \mathrm{Ma}$ in duration (Davydov et al. 2010). Two U-Pb ID-TIMS zircon ages from the Silesian Basin, 328.84 $\pm 0.38 \mathrm{Ma}$ and $328.01 \pm 0.36$ Ma (total uncertainty) from early Pendleian and late Pendleian strata, respectively, have been determined (Gastaldo et al. 2009). These authors extrapolate cycle duration to produce an estimate of $329.7 \mathrm{Ma}$, rounded up to $330 \mathrm{Ma}$ for the base of the Serpukhovian. 
The U-Pb TIMS age of $326.8 \pm 0.98$ Ma of Trapp \& Kaufmann (2002) from Germany is derived from a bentonite found within the ammonoid Goniatites crenistria (P1) Zone of late Asbian age (Waters et al. 2011).

\section{U-Pb Geochronology}

\section{Sample localities}

Bentonites found within Namurian strata comprise typically mixed-layer illite-smectite with subordinate kaolinite (i.e. K-bentonites). The trace element geochemistry is indicative of a rhyodacite-dacite composition for the late Pendleian to Arnsbergian ashfall deposits (Spears et al. 1999). Tonsteins are kaolinite aggregates, typically present in Westphalian strata in the Pennine Basin, interpreted as kaolinised volcanic ash-falls or reworked volcanic detritus, with both acid and basic tonsteins recognised geochemically (Spears \& Kanaris-Sotiriou 1979). Bentonites and tonsteins most likely to contain primary zircons and with minimal siliciclastic contamination were selected. Eleven localities/boreholes were investigated with the aim of providing a broad range of dates for Brigantian (late Visean) to Bolsovian (late Westphalian) strata. However, following heavy mineral separation and age-screening using laser ablation inductively coupled plasma ionisation mass spectrometry (LA-ICP-MS) only two samples contained sufficient primary zircons to make dating chemical abrasion isotope-dilution thermal ionisation mass spectrometry (CA-ID-TIMS, see below) worthwhile.

The bentonite sample BLL1976 from the BGS Harewood Borehole (Fig. 1), West Yorkshire [BNG 4322044410 ] at a depth of $304.10 \mathrm{~m}$, were interpreted by Riley et al. (1995) as representing bentonite B6 of Trewin (1968). BLL1976 occurs within the upper part of the Eumorphoceras yatesae $\left(\mathrm{E}_{2 \mathrm{a}} 3\right)$ Marine Band of early Arnsbergian age and is equivalent to the sample analysed by Riley et al. (1995) for which their SHRIMP U/Pb date of $314.4 \pm 4.6 \mathrm{Ma}$ was acquired using the SL13 zircon standard for $\mathrm{U} / \mathrm{Pb}$ calibration.

Sample EH28155 from the Holme Pierrepont Borehole (Fig. 1), Nottinghamshire [BNG 46306 33933] at a depth of $181.8 \mathrm{~m}$ comes from the Sub-High Main tonstein, located $14 \mathrm{~m}$ above the Aegiranum Marine Band, the base of which marks the base of the Bolsovian regional substage. The stratigraphically nearest dated horizon is the $\mathrm{Z} 1$ tonstein from the Ruhr Coalfield, located just below the Aegiranum Marine Band. Hess \& Lippolt (1986) provide a ${ }^{40} \mathrm{Ar} /{ }^{39} \mathrm{Ar}$ sanidine plateau date of $310.7 \pm 2.6 \mathrm{Ma}(2 \sigma)$ relative to MMHb-1 mineral standard using an age of 519.5 Ma. Claoué-Long et al. (1995) determined 39 measurements of 37 zircons from the $\mathrm{Z} 1$ tonstein, with a mean U-Pb SHRIMP age of $311.0 \pm 3.4 \mathrm{Ma}(2 \sigma)$. 


\section{Results}

Zircons were analysed using CA-ID-TIMS methodologies employed at NERC Isotope Geoscience Laboratory (NIGL), details of which are outlined in an online supplemental material along with the tabulated results of the analytical programme. However, two important points are outlined here: (1) prior to dissolution zircons were subject to a modified chemical abrasion pretreatement for the effective elimination of Pb-loss (Mattinson 2005); and (2) the accuracy of the ${ }^{238} \mathrm{U} /{ }^{206} \mathrm{~Pb}$ dates presented herein are controlled by the gravimetric calibration of the EARTHTIME U-Pb tracer employed in this study and the determination of the ${ }^{238} \mathrm{U}$ decay constant (Condon et al. 2007; Jaffey et al. 1971). Zircons separated from both bentonite samples BLL1976 and EH28155 were small $(<50 \mu \mathrm{m})$ with aspect ratios of $\sim 1.5$ to $\sim 3$. For sample BLL1976 seventeen fractions (single grains) were analysed, with the resulting data presented and their interpretation discussed in more detail in the online supplemental material. In brief, ${ }^{206} \mathrm{~Pb} /{ }^{238} \mathrm{U}$ dates between 311 and $334 \mathrm{Ma}$ (Fig. 2) with a distinct population (defined by 11 of the 17) of analyses yielding a weighted mean ${ }^{206} \mathrm{~Pb} /{ }^{238} \mathrm{U}$ date of $328.34 \pm 0.30(0.43)[0.55]{ }^{1} \mathrm{Ma}$ (Mean square weighted deviation, MSWD = 2.2), which is interpreted as being the best estimate for the zircons of this sample and inferentially the age of bentonite at the sampled stratigraphic level. For sample EH28155 nine fractions (single grains) were analysed, and the resulting data are presented in Figure 2. Two of the nine analyses produced U-Pb dates older than the constraint imposed by sample BLL 1976 (see above). The remaining seven analyses yielded ${ }^{206} \mathrm{~Pb} /{ }^{238} \mathrm{U}$ dates between 306 and $317 \mathrm{Ma}$ (Fig. 2) with a distinct population (defined by 4 of the 7) of concordant anlyses yielding a weighted mean ${ }^{206} \mathrm{~Pb} /{ }^{238} \mathrm{U}$ date of $314.37 \pm 0.25(0.40)[0.53]{ }^{1}$ Ma (MSWD = 1.07) which is interpreted as being the best estimate for the zircons of this sample. In both samples the $\mathrm{U} / \mathrm{Pb}$ dates that are older than the main population are interpeted as reflecting the analyses of zircon ante-/xeno-crysts, and grains that are younger as reflecting $\mathrm{Pb}-$ loss (Fig. 2) and interpretation that is supported by consideration of biostratigraphic and geochronologic constraints (e.g., Davydov et al. 2010).

\footnotetext{
${ }^{1}$ Errors presented in format $\pm \mathrm{X}(\mathrm{Y})[\mathrm{Z}]: \mathrm{X}$ - internal or analytical uncertainty in absence of all systematic error (tracer calibration and decay constants); $\mathrm{Y}$ includes the quadratic addition of tracer calibration error (using a conservative estimate of the $2 \sigma$ standard deviation of $0.1 \%$ for the $\mathrm{Pb} / \mathrm{U}$ ratio in the tracer); $\mathrm{Z}$ includes the quadratic addition of both tracer calibration error and additional ${ }^{238} \mathrm{U}$ decay constant errors (see online supplemental information).
} 
These two new ages for the early Arnsbergian and early Bolsovian are significantly older than existing published U-Pb SHRIMP and ${ }^{40} \mathrm{Ar} /{ }^{39} \mathrm{Ar}$ sanidine plateau dates for equivalent strata in Western Europe. Closer comparison with the ${ }^{40} \mathrm{Ar} /{ }^{39} \mathrm{Ar}$ ages is evident when recalibration of the mineral standard is taken into consideration, but the errors are too great to make the ages of any use in understanding basin evolution timing. The new ages align (within $2 \sigma$ errors) with recent U-Pb ID-TIMS zircon ages from the Donetz Basin (Davydov et al. 2010).

\section{Stratigraphic analyses}

\section{Marine band cyclicity referenced in the Pennine Basin}

The 'cyclicity' of marine bands in the palaeo-equatorial Carboniferous Pennine Basin is considered by many (e.g. Holdsworth \& Collinson 1988; Maynard \& Leeder 1992; Martinsen et al. 1995; Hampson et al. 1997; Waters \& Davies 2006) to be driven by eustatic sea-level fluctuations, a farfield response to polar environmental fluctuations in ice-sheet volume in the southern hemisphere (Veevers \& Powell 1987; Isbell et al. 2003). Many of the marine bands recognised within the Pennine Basin can also be found in separate basins in Scotland, Ireland, northern France, Belgium, Holland and Germany (Ramsbottom 1979), indicating that sea-level rise, as opposed to regional subsidence, was the primary control of marine band formation. This marine band cyclicity is evident throughout strata of Pendleian (early Namurian) to Bolsovian (late Westphalian) age.

The marine bands occur at the base of marine to non-marine upward-coarsening cycles, equating to the parasequence of the Exxon sequence-stratigraphic model (Posamentier et al. 1988). The marine bands are taken to represent transgressive systems tracts and maximum flooding surfaces, with the acme marine facies coinciding with the maximum rate in rise of the sea-level curve (Posamentier et al. 1988). Alternatively, Martinsen et al. (1995) argue that due to the lengthy and sinuous nature of connections between the open sea and the basin, the condensed section represented by each of the ammonoid-bearing marine bands is likely to coincide with a maximum of the sea-level curve.

The periodicity of cyclicity has been estimated at $185 \mathrm{ka}$ (Holdsworth \& Collinson 1988), $120 \mathrm{ka}$ (Maynard \& Leeder 1992), or 65 ka based on SHRIMP U-Pb (zircon) dates (Riley et al. 1995). These values are consistent with eccentricity-forced modulation frequencies. The amplitude of sea-level variation has been estimated at about $42 \mathrm{~m}$ (Maynard \& Leeder 1992) or $60 \mathrm{~m}$ (Church $\&$ Gawthorpe 1994), during the Namurian. The above estimated periodicities were based upon assumptions of a constant forcing during the entire interval and using time intervals for the Namurian which are shown in this study to lack required precision. For example, if we consider the $2 \sigma$ c. 4 Ma uncertainties on the SHRIMP U-Pb (zircon) dates the total duration of this 
interval could range from ca. 0 to $11 \mathrm{Ma}$, or greater if SHRIMP U-Pb (zircon) dates are inaccurate, which has a great effect on the average cycle duration.

The existence of a superimposed higher-frequency obliquity or precession cyclicity, of lesser amplitude, has been proposed within the Pennine Basin (e.g. Brettle 2001; Waters et al. 2008; Tucker et al. 2009). In addition, Ramsbottom (1977) identified long-duration cyclic units, which he termed mesothems. He proposed eleven 'mesothemic' cycles for the British Namurian (Table 2), linked to the appearance of new ammonoid genera, and controlled by longer duration eustatic sea-level fluctuations, which he estimated to have an average duration of 1.1-1.35 Ma (Ramsbottom 1979). Similarly, Ramsbottom (1979) proposed the presence of ten mesothems within the Westphalian succession, of average duration of $1.66 \mathrm{Ma}$, with the lowermost coinciding with the uppermost Namurian mesothem (Table 3). Both Namurian and Westphalian mesothems were described as comprising pulsed marine transgressions in which each successive transgression is increasingly extensive, with the top of the mesothem marked by the most widespread marine band, commonly with a widely developed ammonoid facies (Ramsbottom 1979). The boundaries of the mesothems are marked by widespread disconformities in shelf areas. Sequence-stratigraphic terminology would consider the mesothems to broadly represent sequences (Posamentier et al. 1988), although the mesothem boundaries were taken at the top of major fluvial sandbodies and not at the sequence boundary at the base. The upper cycles of each Namurian mesothem were considered to be typically sandstone-dominated and associated with overall base-level fall and progressive progradation of fluvial systems further into the basin (Ramsbottom 1977). Holdsworth \& Collinson (1988) provided a rigorous critique of the mesothemic concept, arguing that the linkage of sand-dominated cycles with regression and the major ammonoid turnover of taxa at mesothem boundaries could not be demonstrated. They also argued against the lateral extent of ammonoid-bearing marine bands being suitable as a means to deduce the form of major eustatic curves. Holdsworth \& Collinson (1988) also considered that the example used by Ramsbottom (1977) of the transition between the Askrigg Block and Craven Basin (Fig. 1) is invalidated by the potential of tectonic uplift and subsidence influencing the areal extent of marine bands.

\section{New observations on a Namurian-Westphalian marine band cyclostratigraphy}

The areal extent of marine bands is primarily a function of the magnitude of eustatic sea-level rise, influenced by basin topography and subsidence/uplift rates. Hence, to use the areal extents of marine bands as a proxy of relative magnitude of sea-level rise it is important to understand the relative significance of these factors. The Southern Uplands High and Wales-Brabant Massif, 
bounding, respectively, the northern and southern margins of the Pennine Basin (Fig. 1), form topographical highs throughout the Carboniferous, and flooding events do not extend across them. The Namurian to early Westphalian interval covered by this study was a time of the onset of broad thermal subsidence between the Southern Uplands High and Wales-Brabant Massif (Leeder 1982). Waters et al. (1994) provided evidence that pulses of basin extension continued, though on a much reduced scale, during the thermal subsidence phase until Bolsovian times, at which time Variscan compressional structures became increasingly important, culminating in the end Carboniferous inversion of the entire basin. Deformation varied from growth folding within thick successions toward the basin depocentre to development of angular unconformities at the basin margin (Waters et al. 1994). Although such deformation may locally influence the absence of ammonoid fauna in the peripheral parts of the basin for some flooding events, by studying the basin as a whole it is considered that tectonism has no or only minimal influence on the extent of the majority of marine bands.

The 'Block and Basin' topography generated during Late Devonian to Mid Mississippian rifting (Leeder 1982) was gradually infilled by fluvio-deltaic sediments during Namurian times. However, this infilling was a diachronous process, starting in the north of the basin during the Pendleian, and the inherited basinal topography was only largely infilled by fluvio-deltaic sediments in the south by late Marsdenian times (Church \& Gawthorpe 1994; Jones \& Chisholm 1997; Waters \& Davies 2006). Hence, flooding events, particularly during the early Namurian and in the south of the Pennine Basin, were in part constrained to the relict topographical lows associated with former half grabens and grabens, and only the highest sea-level maxima resulted in marine inundation of the block areas. By Westphalian times the fluvio-lacustrine sedimentation was associated with low-profile delta plains occupying the entire basin and in which flooding events were able to extend unconfined across the delta top. Subsidence rates were greatest in the basin depocentre around south Lancashire (Calver 1968), but this was not expressed as a topographical low (Rippon 1996). Hence, during Westphalian times, the marine band extent closely relates to the magnitude of sea-level rise.

The extents of Namurian marine bands within the Pennine Basin have been poorly delineated by previous workers, with the exception of the Cancelloceras (Gastrioceras) cumbriense Marine Band (Wignall 1987). During the current study, only the extent of the acme ammonoid facies was determined, as it is this that displays the diagnostic fauna which allows the unique identification of each marine band. The methodology by which the extents of the marine bands were defined is described in the online supplemental material. The extent of each of the Namurian ammonoid-bearing marine bands is shown in figures 3 and $4 \mathrm{a}-\mathrm{d}$. In contrast, marine 
bands within the Westphalian succession are well documented, with the extents of the various faunal phases shown for each flooding event (Calver 1968, 1969). Only eight of the 24 Westphalian marine bands include an acme ammonoid facies (Table 3) and only those marine bands are delineated in Figure $4 \mathrm{e}-\mathrm{f}$, again showing only the extent of the ammonoid facies. Westphalian marine bands with less diagnostic fauna, such as thin-shelled ammonoids (Anthracoceras), marine bivalves (Dunbarella), brachiopods (Lingula) and foraminifera, record a transition in salinity from marine to brackish environments, with four of the marine bands characterised by the presence of the branchiopod crustacean Estheria, interpreted as occurring within a transitional zone between swamp and marine environments (Calver 1968).

The early Namurian marine bands show compartmentalisation within small areas. This in part reflects the prominent basin topography at the time, with flooding events tending to be limited in extent to the unfilled Visean sub-basins. Also, the outcrop of these successions is relatively isolated, with successions of this age poorly known at depth within the central part of the basin. Furthermore, many of the early Namurian marine bands occur within mudstone-dominated successions lacking intervening deltaic intervals, making identification of the specific marine band at times difficult. As a result, fewer early Namurian exposures were included in the study compared with later Namurian marine bands. Consequently, comparisons between early Namurian and late Namurian magnitudes of sea-levels should be done with care, but within each of these intervals, comparison of individual flooding event extents was considered justifiable.

By Marsdenian times, the ammonoid facies components of marine bands appear to be more laterally extensive, centred upon the area of greatest magnitude of subsidence in south Lancashire (Fig. 4b-c). The pre-Namurian basin topography was largely infilled and accommodation space was the product of eustatic sea-level rises in combination with broad thermal subsidence of the Pennine Basin. This pattern continued into Langsettian and Duckmantian times (Fig. 4e-f). Bolsovian marine bands appear to show a slight shift of the focus of the ammonoid facies eastwards, towards the East Midlands, and are generally less extensive. The Cambriense Marine Band represents the final marine flooding event to affect the Pennine Basin (Guion et al. 1995; Aitkenhead et al. 2002; Waters et al. 2011).

\section{Incised valley fills in the Pennine Basin and evidence for major regressive events} Discontinuities and unconformities are present within the Pennine Basin, though it is only within recent decades that their significance has been recognised. These major Type 1 unconformities, evident as incised palaeovalleys, represent sequence boundaries (Posamentier et al. 1988). Although many cycles include an upper fluvial-deltaic component, there has been a tendency to 
over interpret all boundaries with an overlying coarser grained succession to represent a Type 2 sequence boundary. The significance of these surfaces, whether they be the product of sea-level falls complementing sea-level rises indicated by the marine bands, or through deltaic avulsion during distinct flooding events, remains controversial (Waters et al. 2008) and, as a result, Type 2 sequence boundaries are not considered in this study. A number of Namurian and Westphalian thick, multi-storey fluvial complexes have been interpreted as sediments deposited in palaeovalleys generated by incision during significant sea-level fall.

Most Namurian-aged multi-storey sandstone bodies are $10-30 \mathrm{~km}$ wide and the preserved thickness is 25-35 m (Davies et al. 1999). Much of the evidence for low base levels and fluvial incision during the early Namurian comes from the comparatively condensed successions above the Alston and Askrigg Blocks (Fig. 1). Above the Alston Block, the Rogerley Channel (Fig. 3a), of north-south orientation, is up to $4 \mathrm{~km}$ wide and is associated with up to $30-40 \mathrm{~m}$ of erosional relief, including localised removal of the marine Knucton Shell Bed (Dunham 1990). The incised valley formed at approximately the same time as a major intra- $E_{1 c}$ angular unconformity, associated with the northward tilting and subsequent erosion of the Askrigg Block (Brandon et al. 1995). Within the lowermost Arnsbergian $\mathrm{E}_{2 \mathrm{a}} 1$ cycle of the western part of the Askrigg Block (Fig. 3b), a lowstand erosion surface is recognised below the Upper Howgate Edge Grit (Martinsen 1993; Martinsen et al. 1995), though with insufficient erosion to remove the underlying Cravenoceras cowlingense Marine Band (Table 2). A younger Arnsbergian succession on the Askrigg Block (Fig. 3b) includes a prominent intra- $\mathrm{E}_{2 \mathrm{a}} 3$ unconformity below the Red Scar Grit (and equivalent sandstones). An erosional relief of up to $100 \mathrm{~m}$, associated with the removal of four marine bands may in part coincide with tectonic activity (Brandon et al. 1995). An intra- $E_{2 c} 2$ erosion surface at the base of the Lower Follifoot Grit in the southeast of the Askrigg Block (Fig. 3c) is associated with complete removal of the $E_{2 c} 1$ cycle, with the unconformity resting upon the $\mathrm{E}_{2 \mathrm{~b}} 3$ marine band (Martinsen 1993; Martinsen et al. 1995). An unconformity is demonstrated in the northern part of the Craven Basin, occurring immediately beneath the $\mathrm{H}_{1 \mathrm{a}} 3$ marine band, with spores of $\mathrm{E}_{2 \mathrm{c}} 4$ present beneath the erosive surface, but no incised valley fill sandbody is recorded (Owens et al. 1990). In the southeastern part of the Askrigg Block (Fig. 3d), the markedly erosive base of the fluvial channel of the Upper Follifoot Grit, with pedogenically modified interfluves, suggest base level fall within the $\mathrm{H}_{1 \mathrm{~b}} 2$ subzone (Martinsen 1993).

Kinderscoutian to Yeadonian sandbodies have been subject to the most scrutiny within the central part of the Pennine Basin, with two distinct settings for development of incision. Some valley fills show a marked increase in thickness towards, and immediately upstream of the mouth 
of the incised valley, developed in association with turbidite-fronted deltas within steep submarine slopes. These sandbodies thicken from $20-30 \mathrm{~m}$ to $50-80 \mathrm{~m}$ over a distance of 2-5 km and are filled with giant foresets (Hampson et al. 1999). These valley fills occur within the earliest deltaic infill of the Pennine Basin, ranging from Kinderscoutian within the central part of the basin, to Yeadonian in the south. In contrast, extensive sheet-like sandstones, up to $45 \mathrm{~m}$ thick and up to $70 \mathrm{~km}$ wide (Hampson et al. 1999), develop mainly within Marsdenian to Yeadonian successions and are associated with little basinal topography.

The Kinderscoutian Lower Kinderscout Grit (Hampson 1997) and associated basal turbidite channel of the Todmorden Grit (Fig. 4a), of probable $\mathrm{R}_{1 \mathrm{c}} 3$ age, display local erosion of two $\mathrm{R}_{1 \mathrm{c}}$ marine bands. The uppermost Kinderscoutian cycle includes a marked erosive surface at the base of the Upper Kinderscout Grit (Fig. 4a), which locally erodes through the Butterly ( $\left.\mathrm{R}_{1 \mathrm{c}} 5\right)$ Marine Band (Hampson 1997). The extensive sheet-like Marsdenian Midgley Grit (Fig. 4b) shows incision of the underlying $\mathrm{R}_{2 b} 3$ marine band (Brettle 2001). The erosive base of the Marsdenian Roaches Grit/Ashover Grit is associated with a palaeovalley up to $80 \mathrm{~m}$ deep (Jones \& Chisholm 1997), which removes the underlying $R_{2 b} 5$ marine band within the eastern part of the Widmerpool Gulf (Fig. 4b; Church \& Gawthorpe 1994). The east-west palaeochannel of Chatsworth Grit (Fig. 4c) is $25 \mathrm{~km}$ wide with a steep $50 \mathrm{~m}$ high northern flank, though the incision has not removed underlying marine bands (Waters et al. 2008). The late Yeadonian Rough Rock is typically a low-sinuousity broad sheet-like fluvial sandbody. However, within the Widmerpool Gulf and East Midlands Shelf a north-south incised valley in excess of $11 \mathrm{~km}$ width (Fig. 4d) incises up to 5 marine bands, down to and including the $\mathrm{R}_{2 \mathrm{c}} 2$ Marine Band (Church \& Gawthorpe 1994; Hampson et al. 1997).

The early Langsettian Crawshaw Sandstone of the East Midlands Shelf is less than $70 \mathrm{~km}$ wide (Fig. 4e) and has well defined margins with identifiable interfluves and removes up to three marine bands including the Subcrenatum and $\mathrm{G}_{1 \mathrm{~b}} 1$ marine bands (Hampson et al. 1997). This is the last representative of this style of fluvial deposition within the Pennine Basin. Subsequent fluvial systems are characterised by less laterally extensive sandstone bodies, typically up to 20 $\mathrm{km}$ wide, with a maximum of $30 \mathrm{~km}$, and 8-20 m thick with a maximum of $100 \mathrm{~m}$ (Guion et al. 1995; Aitken et al. 1999). The presence of incised valley fills within this Westphalian succession remains controversial. Regionally developed well-drained palaeosols, considered to form on the interfluve, are not common, and major fluvial sandbodies show only limited basal incision of up to $5 \mathrm{~m}$, exceptionally up to $8 \mathrm{~m}$ (Rippon 1996). This may reflect distance from the sea, with incision of river channels having insufficient time to work upstream from the coast before the next flooding event (Aitkenhead et al. 2002). Alternatively, it may relate to the enclosed nature 
of the basin. Only the highest global sea-level rises would result in a rapid base-level rise within the basin, with the subsequent fall in sea-level leaving an isolated basin for which base levels may fall comparatively slowly as it continues to be fed by rivers (Waters \& Davies 2006).

Westphalian multi-storey sandbodies commonly show a relationship with their adjacent strata. This may include high ash contents in coals adjacent to the sandbodies, coal splitting towards channels and an increase in interbedded sandstone layers in proximity to the channel bodies (Aitken et al. 1999; Guion et al. 1995). These observations imply that overbank flooding events from the channels occurred during peat accumulation and leads these authors to believe that many of the channel systems were aggradational, as opposed to having filled previously incised valley systems.

The Duckmantian and Bolsovian succession includes a number of multistorey sandstone bodies with local basal erosional relief that represent candidate incised valley fills (Fig. 4f). The basal Duckmantian Thornhill Rock cuts through the Vanderbeckei Marine Band (Lake 1999) and reaches thicknesses of $37-45 \mathrm{~m}$. The Woolley Edge Rock is distinctly coarser grained and pebbly compared with earlier Westphalian sandbodies. The channel fill, about $23 \mathrm{~km}$ wide, shows palaeocurrents to the west or WNW and has up to $60 \mathrm{~m}$ of erosional truncation (Aitken et al. 1999), including removal of the Manton Estheria Band. The Oaks Rock, up to $40 \mathrm{~m}$ thick, is similarly associated with the absence of the Haughton and Sutton marine bands (Lake 1999). The early Bolsovian Mexborough Rock is the fill of an east-west channel, 30-40 m thick (locally up to $80 \mathrm{~m}$ ) and 15-30 km wide (Aitken et al. 1999) and may be associated with erosion of the Main Estheria Band and Edmondia Band.

\section{Discussion}

The recognition of cyclic sedimentation offers the potential to develop high-resolution timethickness models for sedimentary successions, in which the resolution is determined by the dominant forcing mechanism. This approach is routinely applied to Cenozoic strata and the current Neogene Timescale (Gradstein et al. 2004) is based entirely upon astronomical calibration. Milankovitch orbital forcing during the Carboniferous is thought to be $413 \mathrm{ka}$ and $112 \mathrm{ka}$ for longand short-duration eccentricity periodicities, respectively, 34 ka for obliquity and 21 ka and 17 ka for precession frequencies (Maynard \& Leeder 1992).

The late Mississippian to Pennsylvanian is a time of high frequency-high amplitude sea-level oscillations during icehouse conditions. The presence of cyclic stratigraphy in the Pennine Basin, evidenced by the presence of cyclothems and periodic development of marine bands, has lead many workers to suggest these can be used to generate high-resolution age-models for parts of the 
Carboniferous (Ramsbottom 1977; Maynard \& Leeder 1992; Brettle 2001; Waters et al. 2008; Tucker et al. 2009). Recent developments in high-precision U-Pb geochronology means that it is now possible to test some of these hypotheses and develop more accurate models for the evolution of a Carboniferous cyclostratigraphy.

Most attempts at estimating the duration of the Namurian and Westphalian cyclicity have assumed a constant forcing mechanism during the entire interval; simply duration divided by the number of marine bands (fossiliferous carbonaceous mudstones or impure limestones). The new radiometric ages from this study combined with the most recent and accurate estimates of 330 Ma and 322.8 Ma for the base of the Serpukhovian and Bashkirian, respectively (Davydov et al., 2010), permit the detailed analysis of cyclicity duration over specific time intervals.

There are 15 marine bands in the $1.66 \mathrm{Ma}$ interval between the base of the Pendleian to the dated bentonite (BLL1976) of early Arnsbergian age (Table 2; Fig. 5). The average duration of ca. 111 ka represents a possible short-duration eccentricity modulation. Four peak flooding events are recognised $\left(E_{1 \mathrm{a}} 1, \mathrm{E}_{1 \mathrm{c}} 1, \mathrm{E}_{2 \mathrm{a}} 1\right.$ and $\left.\mathrm{E}_{2 \mathrm{a}} 3\right)$, which are equated with the 400 ka long-duration eccentricity frequency and identified as the orbital cycles S1 to S4.

The mid to late Arnsbergian interval between the dated bentonite (BLL1976) and the base of the Bashkirian Stage, which occurs above the $\mathrm{H}_{1 \mathrm{a}} 1$ marine band (Riley et al. 1995), there are 13 marine bands over a duration of $5.54 \mathrm{Ma}$ (Table 2; Fig. 5). The average of ca. $426 \mathrm{ka}$ may suggest that only the long-duration eccentricity frequency is observed. However, the marine bands $\mathrm{E}_{2 \mathrm{~b}} 1 \mathrm{a}-\mathrm{c}, \mathrm{E}_{2 \mathrm{~b}} 2 \mathrm{a}-\mathrm{c}, \mathrm{E}_{2 \mathrm{c}} 2-4$ and $\mathrm{H}_{1 \mathrm{a}} 1-3$ occur as triple short-duration flooding events associated with the same ammonoid fauna (see below), and are considered to represent only four $400 \mathrm{ka}$ flooding events. If these four, along with the $E_{2 b} 3$ and $E_{2 c} 1$ are taken to represent peak flooding events, it requires that eight $400 \mathrm{ka}$ cycles are not represented in the geological record by marine flooding events (Fig. 5). It is possible that these missing cycles may be distributed evenly throughout the mid to late Arnsbergian interval. However, the very marked change in ammonoid genera between the $\mathrm{E}_{2 \mathrm{c}} 4$ and $\mathrm{H}_{1 \mathrm{a}} 1$ flooding events is here interpreted as indicative of a long period without marine flooding of the basin. During the Pendleian and Arnsbergian the dominant genera are Cravenoceras, Eumorphoceras and Cravenoceratoides, but these genera are absent from Chokierian and younger strata (Table 2).

Between the base of the Bashkirian Stage and the dated early Bolsovian tonstein (EH28155) there are 56 marine bands in the Pennine Basin (Tables $2 \&$ 3; Fig. 5) over an interval of 8.43 Ma. This results in an average marine band cycle of ca. $150 \mathrm{ka}$, a possible short-duration eccentricity modulation. However, these high-frequency events appear to be less common during 
the early to mid Kinderscoutian and late Marsdenian to Yeadonian. Twenty one peak flooding events are recognised between the $\mathrm{H}_{1 b} 1$ to Aegiranum marine bands, which are equated with the $400 \mathrm{ka}$ long-duration eccentricity frequency and identified as the orbital cycles B2 to M2 (Fig. 5). Eight out of the 24 Westphalian marine bands are associated with ammonoid assemblages (Table 3), of which seven of these marine bands, along with the brachiopod-bearing Haughton Marine Band, are recognised as representing the 400 ka peak flooding events.

A common feature of many of the Namurian marine bands is the presence of two or three distinct beds with marine fauna, separated by non-marine barren mudstones. In many cases the separation between these bands is only a few tens of centimetres to metres scale, e.g. $E_{1 \mathrm{a}} 1$ (a-c) or $\mathrm{E}_{2 \mathrm{a}} 1(\mathrm{a}-\mathrm{c})$, but in other cases they are separated by tens of metres of succession, including prograding deltaic lobes, e.g. $\mathrm{R}_{1 \mathrm{c}} 1-3$ or $\mathrm{R}_{2 \mathrm{~b}} 1-3$. Importantly, these distinct "leaves" show the same ammonoid assemblages and cannot be readily distinguished, unless all "leaves" are evident in a single section or through correlation of intervening deltaic sandbodies. If one assumes a constancy of rate of evolution of ammonoid species through the Namurian it would suggest that these multiple marine bands occur at higher frequencies than between marine bands with distinct ammonoid taxa. This would suggest shorter frequencies than the $111 \mathrm{ka}$ or 150 ka periodicities recognised above, and may indicate evidence of precession or obliquity components of too short a duration to be determined through current radiometric dating techniques.

Throughout the Namurian and Westphalian, 17 major base-level falls are recognised, at a frequency of about $1 \mathrm{Ma}$ (Fig. 5). This long-duration cyclicity broadly approximates to the periodicity of the "mesothems" of Ramsbottom $(1977 ;$ 1979). These major regressive events occur at greatest frequency during late Pendleian to late Arnsbergian, Chokierian, late Kinderscoutian to early Langsettian and Duckmantian to early Bolsovian times, but appear to be absent throughout much of the late Arnsbergian, Alportian to mid Kinderscoutian and Langsettian.

The variations in development of unconformities within the Pennine Basin may be a far-field response to the record of alternating glacial and non-glacial climatic regimes proposed for Gondwana. The onset of the main phase of glaciation began in the early Namurian and peaked in the late Westphalian and Stephanian (Gonzalez-Bonorino \& Eyles 1995). Isbell et al. (2003) recognised an early Visean alpine glaciation event, but considered the main continental glaciation to persist across Gondwana from early Serpukhovian to Permian times, with a phase of minimal ice during latest Bashkirian to early Moscovian times. Fielding et al. (2008) indicate that eastern Australia was affected by four major glaciations during the Carboniferous, each separated by non-glacial periods of similar duration. Their estimates for the ages of these 
glaciations are based upon U-Pb SHRIMP dates (e.g. Claoué-Long et al. 1995, Roberts et al. 1995), now considered unsuitable (see summary of existing dates above). Within the Paganzo Basin of Argentina, three glacial pulses during the mid Visean, early Bashkirian (c. 323-319.57 $\pm 0.09 \mathrm{Ma})$ and latest Bashkirian to early Moscovian (315.46 $\pm 0.07-312.82 \pm 0.11 \mathrm{Ma})$ are well constrained by U-Pb ID-TIMS dates from zircons (Gulbranson et al., 2010). The timing and duration of glaciations remain problematic and until redating occurs in Eastern Australia, the farfield response to these glaciations may provide the most suitable method for estimating their ages.

Glaciation C1 of earliest Namurian age, proposed by Fielding et al. (2008) to represent the initiation of the Late Palaeozoic Ice Age, is of limited extent and short-duration. In the study area, Type 1 unconformities are developed during the late Pendleian to early Arnsbergian and tend to be limited to the basin margin (Fig. 3). These unconformities follow after three of the four peak flooding events described earlier (Fig. 5), suggesting linkage to the 400 ka eccentricity frequency. This early Serukhovian glaciation is considered to range from orbital cycles S1 to S9, approximately 330.0 to $326.5 \mathrm{Ma}$ (Fig. 5). The start of Cycle S1 coincides with the sudden cessation of platform carbonate deposition and Cycles S2 to S5, between the $\mathrm{E}_{1 \mathrm{c}} 1$ and $\mathrm{E}_{2 \mathrm{a}} 3$ marine bands, is marked by the first phase of thick fluvio-deltaic siliciclastic sandbodies entering the basin (Aitkenhead et al. 2002; Waters \& Davies 2006).

An absence of Type 1 unconformities and inferred absence of eight 400 ka cycle flooding events during the mid to late Arnsbergian may represent the interval between the $\mathrm{C} 1$ and $\mathrm{C} 2$ glaciations. Isbell et al. (2003) considered there to be evidence of glaciations in South America and Tibet in this interval. However, Stephenson et al. (2010) have demonstrated using $\delta^{18} \mathrm{O}$ and $\delta^{13} \mathrm{C}$ from the Pennine Basin that widespread ice-caps were absent throughout mid Serpukhovian times. This interval is considered to range from orbital cycles S10 to S17, approximately 326.5 to $323.0 \mathrm{Ma}$ (Fig. 5). Few large sandbodies prograded into the Pennine Basin during this time interval (Aitkenhead et al. 2002; Waters \& Davies 2006).

The Glaciation C2 of mid-Namurian age, estimated to range from 322.5-319.5 Ma by Fielding et al. (2008) is coincident with the second glacigenic phase in Argentina (Gulbranson et al., 2010). It broadly aligns with the phase of Chokierian to Alportian increased frequency of unconformities and marine flooding events. This early Bashkirian glaciation is considered in this study to range from orbital cycles B1 to B4, approximately 323.0 to $321.5 \mathrm{Ma}$ (Fig. 5). This was a time when the Pennine Basin was dominated by slow hemipelagic deposition with comparatively few large sandbodies prograding into the basin (Waters \& Davies 2006). 
The early to mid Kinderscoutian within the Pennine Basin is marked by low magnitude variations in sea-level, no major incision events and no multiple (high-frequency) marine bands. Deposition at this time was dominated by slow accumulation of hemipelagic and distal turbidite deposits (Waters \& Davies 2006). It is suggested that this may equate with the interval between Glaciations $\mathrm{C} 2$ and $\mathrm{C} 3$, during which eustatic sea-level fluctuations are more subdued, but suggests not completely free of ice-sheet development. As with the $\mathrm{C} 1-\mathrm{C} 2$ interglacial, this interval is associated with a marked turnover of ammonoid genera, most notably marked by the appearance of Reticuloceras (Table 2). This interval is considered to range from orbital cycles B5 to B9, approximately 321.5 to $319.5 \mathrm{Ma}$ (Fig. 5).

The latest Namurian to earliest Westphalian Glaciation C3, estimated by Fielding et al. (2008) to range of 317-315 Ma, was considered to have a comparable areal extent to Glaciation C2. No equivalent of this glaciation is recorded in the Paganzo Basin of Argentina (Gulbranson et al., 2010). This broadly coincides with the late Kinderscoutian to early Langsettian phase in the Pennine Basin of highest magnitude sea-level flooding events and most numerous incision surfaces, almost on a $\sim 400$ ka cyclicity, with a return to common multiple (high-frequency) marine bands. In contrast to the early Namurian event, these unconformities commonly follow trends of decreasing amplitude flooding events. The onset of this glaciation is evident through a rapid and almost basinwide progradation of coarse, pebbly and commonly sheet-like fluviodeltaic sandbodies, with this style of deposition persisting throughout this interval (Waters \& Davies 2006). This glaciation is considered to range from orbital cycles B10 to B18, approximately 319.5 to $316.0 \mathrm{Ma}$ (Fig. 5).

The short-lived interglacial interval between $\mathrm{C} 3$ and $\mathrm{C} 4$ equates with the mid- to late-Langsettian succession, possibly representing an interval of up to two orbital cycles (B18 to B20). The interval follows the Listeri Marine Band, the most extensive of all of the flooding events (Fig. 5), after which sea-level fluctuations are diminished and major incision surfaces are not recorded. The interval also records a marked dimunition of sandbody dimension and grainsize (Guion et al. 1995; Waters \& Davies 2006). As for the C2-C3 interglacial, this interval appears not to be completely free of ice-sheet development.

The youngest mid-Westphalian Glaciation C4, estimated by Fielding et al. (2008) to range from 313-308 Ma, is thought to be in part coincident with the third glacigenic phase in Argentina (Gulbranson et al., 2010). It may equate with the Duckmantian to early Bolsovian phase of highfrequency major flooding and incision events (Fig. 5). The expression of this glaciation in the Pennine Basin is considered to range from orbital cycles B20 to M3, approximately 315.2 to 314.0 Ma (Fig. 5). 


\section{Conclusions}

This study provides two new high-precision $\mathrm{U} / \mathrm{Pb}$ ages of $328.34 \pm 0.55 \mathrm{Ma}$ (total uncertainty) for the Arnsbergian regional substage (mid-Serpukhovian stage) and $314.37 \pm 0.53 \mathrm{Ma}$ (total uncertainty) for the earliest Bolsovian regional substage (early Moscovian stage). These ages are somewhat older than existing published ages for these successions and require modification of the current timescale for the Western Europe regional chronostratigraphy, but align with recent dates provided by Davydov et al. (2010) for the Donetz Basin.

The extent of acme ammonoid facies within discrete marine intervals is used as a proxy of the magnitude of these marine flooding events. The recognition of candidate incised valleys, and the number of cycles locally removed by these major sequence boundaries, is used as a proxy of the magnitude of sea-level falls. The frequency of these events, when considered in the light of the new radiometric dating indicates the following relationships:

1) The interval between major sequence boundaries within the Namurian and Westphalian is approximately 1 Ma. This cyclicity may be a far-field response to the record of alternating glacial and non-glacial climatic regimes proposed for Gondwana. The four major glaciations proposed for Gondwana may equate with phases of increased numbers of sequence boundaries in the Pennine Basin. It is suggested that the main glaciations occurred during the late Pendleian to late Arnsbergian (approximately 330.0 to 326.5 Ma), Chokierian to Alportian (approximately 323.0 to $321.5 \mathrm{Ma}$ ), late Kinderscoutian to early Langsettian age (approximately 319.5 to $316.0 \mathrm{Ma}$ ) and Duckmantian to early Bolsovian (approximately 315.2 to $314.0 \mathrm{Ma}$ ).

2) The interglacial intervals are associated with no development of incised valleys, no or reduced frequency of flooding events and marked turnover of ammonoid genera, considered to mark long time durations between successive flooding events.

3) Distinct peak flooding surfaces within Namurian strata, associated with ammonoidbearing marine bands in the Westphalian succession, have an average frequency of 400 $\mathrm{ka}$, equating with the long-duration eccentricity component described in mid- to latePennsylvanian strata in the USA.

4) Average durations of marine band cycles during the Pendleian to early Arnsbergian and Chokierian to Bolsovian, of $111 \mathrm{ka}$ and $150 \mathrm{ka}$, respectively, may reflect a short-duration eccentricity component. These flooding events are associated with non-ammonoid marine fauna in the Westphalian succession. 
554 555

556

557

558

559

560

561

562

563

564 565

5) Multiple flooding surfaces associated with the same ammonoid assemblages in the Namurian may equate with sub-100 ka precession or obliquity frequencies.

The interaction of cyclicities associated with long-duration switching from glacial and nonglacial climatic regimes and long- and short-duration eccentricity cycles offers the opportunity of trans-continental cyclostratigraphical correlations within late Mississippian to Pennsylvanian successions.

\section{Acknowledgements}

Mike Stephenson and Steve Noble are thanked for helpful comments on an earlier draft of this paper and J S Daly and V Davydov for their helpful reviews of the manuscript. The help of Mike Howe (National Geoscience Information Service) in providing access to BGS borehole core and palaeontological databases is much appreciated. Colin Waters and Daniel Condon publish with the permission of the Executive Director, British Geological Survey, Natural Environment Research Council. U-Pb (zircon) analyses were supported by NIGFSC grant IP/949/1106. 


\section{References}

AITKEN, J.F., QUIRK, D.G. \& GUION, P.D. 1999. Regional Correlation of Westphalian sandbodies onshore UK: implications for reservoirs in the Southern North Sea. In: FLEET, A.J. \& BoLDY, S.A.R. (eds). Petroleum Geology of Northwest Europe. Proceedings of the 5th Conference. Geological Society of London, 747-756.

Aitkenhead, N., Barclay, W.J., Brandon, A., Chadwick, R.A., Chisholm, J.I., CoOper, A.H. \& Johnson, E.W. (eds). 2002. British regional geology: The Pennines and adjacent areas. (4th edition). HMSO, London.

Brandon, A., Riley, N.J., Wilson, A.A. \& Ellison, R.A. 1995. Three new early Namurian (E1c-E2a) marine bands in central and northern England, UK, and their bearing on correlations with the Askrigg Block. Proceedings of the Yorkshire Geological Society, 50, $333-355$.

BRETTLE, M.J. 2001. Sedimentology and high-resolution sequence stratigraphy of shallow water delta systems in the early Marsdenian (Namurian) Pennine basin, Northern England. PhD thesis, University of Liverpool.

BuRgER, K., HeSS, J.C. \& LIPPOLT, H.J. 1997. Tephrochronologie mit Kaolin-Kohlentonsteinen: Mittel zur Korrelation paralischer und limnischer Ablagerungen des Oberkarbons. Geologisches Jahrbuch, A147, 3-39.

CALVER, M.A. 1968. Distribution of Westphalian marine faunas in northern England and adjoining areas. Proceedings of the Yorkshire Geological Society, 37, 1-72.

CALVER, M.A. 1969. Westphalian of Britain. Compte Rendu 6e Congrès Internationale Stratigraphie et Géologie Carbonifère, Sheffield, 1967, I, 233-254.

ChURCH, K.D. \& GAWTHORPE, R.L. 1994. High resolution sequence stratigraphy of the late Namurian in the Widmerpool Gulf (East Midlands, UK). Marine and Petroleum Geology, 11, 528-544.

Claoué-Long, J.C., Compston, W., Roberts, J. \& Fanning, C.M. 1995. Two Carboniferous ages: a comparison of SHRIMP zircon dating with conventional zircon ages and ${ }^{40} \mathrm{Ar} /{ }^{39} \mathrm{Ar}$ analysis. SEPM Special Publication, 54, 3-21.

Condon, D., Schoene, B., Bowring, S., Parrish, R., Mclean, N., Noble, S. \& Crowley, Q. 2007. EARTHTIME; isotopic tracers and optimized solutions for high-precision U-Pb ID-TIMS geochronology. Eos, Transactions, American Geophysical Union, 88. 
Davies, S.J., HAmpson, G.J., Flint, S.S. \& ElLiotT, T. 1999. Continental-scale sequence stratigraphy of the Namurian, Upper Carboniferous and its applications to reservoir prediction. In: FLEET, A.J. \& BOLDY, S.A.R. (eds). Petroleum Geology of Northwest Europe: Proceedings of the 5th Conference. Geological Society of London, 757-770.

Davydov, V.I., Wardlaw, B.R., \& GradsteIn, F.M. 2004. The Carboniferous Period. In: Gradstein, F.M., OGG, J.G., \& SMith, A.G. (eds). A geologic time scale 2004. Cambridge University Press, 222-248.

Davydov, V.I., Crowley, J.L., Schmitz, M.D., \& Poletaev, V.I. 2010. High-precision U-Pb zircon age calibration of the global Carboniferous time scale and Milankovitch band cyclicity in the Donets Basin, eastern Ukraine. Geochemistry Geophysics Geosystems, 11, Q0AA04, doi:10.1029/2009GC002736.

Dunham, K.C. 1990. Geology of the Northern Pennine Orefield, Volume 1: Tyne to Stainmore. Economic Memoir of the British Geological Survey, Sheets 40, 41 and 50. (London: HMSO.)

Fielding, C.R., Frank, T.D., Birgenheier, L.P., Rygel, M.C., Jones, A.T., \& Roberts, J. 2008. Stratigraphic imprint of the Late Palaeozoic Ice Age in eastern Australia: a record of alternating glacial and nonglacial climate regime. Journal of the Geological Society, 165, $129-140$.

Gastaldo, R.A., PURKYŇÁ, E., ŠIMŮNeK, Z. \& SChMitZ, M.D. 2009. Ecological persistence in the Late Mississippian (Serukhovian, Namurian A) megafloral record of the Upper Silesian Basin, Czech Republic. Palaios, 24, 336-350. DOI: 10.2110/palo.2008.p08-084r.

GonZALEZ-BonORINO, G. \& EYLES, N. 1995. Inverse relation between ice extent and the late Paleozoic glacial record of Gondwana. Geology, 23, 1015-1018.

Gradstein, F.M., OGG, J.G., \& Smith, A.G. 2004. A Geologic Time Scale. Episodes, 19, 3-4. (Cambridge University Press).

GUION, P.D., Fulton, I.M. \& JoneS, N.S. 1995. Sedimentary facies of the coal-bearing Westphalian A and B north of the Wales-Brabant High. In: Whateley, M.K.G. \& SpEARs, D.A. (eds.). European Coal Geology. Geological Society Special Publication, 82, $45-78$.

Gulbranson, E.L, MontaÑez, I.P., Schmitz, M.D., Limarino, C.O., Isbell, J.L., Marenssi, S.A. \& CRowley, J.L. 2010. High-precision U-Pb calibration of Carboniferous glaciation 
and climate history, Paganzo Group, NW Argentina. Geological Society of America Bulletin, 122, 1480-1498. doi: 10.1130/B30025.1.

HAMPSON, G.J. 1997. A sequence stratigraphic model for deposition of the Lower Kinderscout Delta, an Upper Carboniferous turbidite-fronted delta. Proceedings of the Yorkshire Geological Society, 51, 273-296.

HAMPSON, G.J., ElLIOTT, T. \& DAVIES, S.J. 1997. The application of sequence stratigraphy to upper Carboniferous fluvio-deltaic strata of the onshore UK and Ireland: Implications for the southern North Sea. Journal of the Geological Society, London, 154, 719-733.

Hampson, G.J., Davies, S.J., Elliott, T., Flint, S.S. \& Stollhofen, H. 1999. Incised valley fill sandstone bodies in Upper Carboniferous fluvio-deltaic strata: recognition and reservoir characterization of Southern North Sea analogues. In: FLEET, A.J. \& BoldY, S.A.R. (eds). Petroleum Geology of Northwest Europe: Proceedings of the 5th Conference. Geological Society of London, 771-788.

Hess, J.C. \& LiPPOLT, H.J. $1986 .{ }^{40} \mathrm{Ar} /{ }^{39} \mathrm{Ar}$ ages of tonstein and tuff sanidines: new calibration points for the improvement of the Upper Carboniferous time scale. Chemical Geology, 59, $143-154$.

Holdsworth, B.K. \& Collinson, J.D. 1988. Millstone Grit cyclicity revisited. In: Besly, B.M. \& Kelling, G. (eds). Sedimentation in synorogenic basin complex; the Upper Carboniferous of North West Europe. Blackie, Glasgow and London, 132-152.

IRELAND, T.R. \& WiLLIAMS, I.S., 2003, Considerations in Zircon Geochronology by SIMS. Reviews in Mineralogy and Geochemistry, 53, 215-241.

Isbell, J.L., Miller, M.F., Wolfe, K.L. \& LeNAKER, P.A., 2003, Timing of late Paleozoic glaciation in Gondwana: Was glaciation responsible for the development of Northern Hemisphere cyclothems? In: ChAn M.A. \& ARCHER A.W. (eds). Extreme Depositional Environments: Mega End Members in Geologic Time. Geological Society of America Special Paper 370, 5-24.

JAfFey, A.H., Flynn, K.F., Glendenin, L.E., BentLey, W.C. \& Essling, A.M. 1971. Precision Measurement of Half-Lives and Specific Activities of ${ }^{235} \mathrm{U}$ and ${ }^{238} \mathrm{U}$. Physical Review $C$, 4, 1889-1906. 
JoNES, C.M. \& ChISHOLM, J.I. 1997. The Roaches and Ashover Grits: sequence stratigraphic interpretation of a 'turbidite fronted delta' system. Geological Journal, 32, 45-68.

Kryza, R, Muszer, J, Haydukiewicz, J, August, C, JuRasik, M, \& Rodionov, N. 2010. A SIMS zircon age for a biostratigraphically dated Upper Viséan (Asbian) bentonite in the Central-European Variscides (Bardo Unit, Polish Sudetes). International Journal of Earth Sciences, DOI: 10.1007/s00531-010-0529-y.

LAKE, R.D. 1999. The Wakefield district - a concise account of the geology. Memoir of the British Geological Survey. Sheet 78 (England and Wales).

LEEDER, M.R. 1982. Upper Palaeozoic basins of the British Isles: Caledonide inheritance versus Hercynian plate margin processes. Journal of the Geological Society London, 139, 481494.

MARTinSEn, O.J. 1993. Namurian (late Carboniferous) depositional systems of the CravenAskrigg area, northern England: implications fro sequence stratigraphic models. In: Posamentier, H.W., Summerhayes, C.P., HaQ, B.U. \& Allen, G.P. (eds) Stratigraphy and Facies associations in a Sequence Stratigraphic Framework, 247-281.

Martinsen, O.J., Collinson, J.D. \& HoldSwORTH, B.K. 1995. Millstone Grit cyclicity revisited, II: sequence stratigraphy and sedimentary responses to changes of relative sea-level. In: PLINT, A.G. (ed.) Sedimentary facies analysis. International Association of Sedimentologists Special Publication, 22, 305-327. Blackwell Scientific, Oxford.

MAtTinson, J M. 2005. Zircon U-Pb chemical abrasion ("CA-TIMS") method: Combined annealing and multi-step partial dissolution analysis for improved precision and accuracy of zircon ages. Chemical Geology, 220, 47-66.

MAYNARD, J.R. \& LEEDER, M.R. 1992. On the periodicity and magnitude of Late Carboniferous glacio-eustatic sea-level changes. Journal of the Geological Society London, 149, 303311.

OgG, J.G., OGG, G., and Gradstein, F.M. 2008. The Concise Geologic Time Scale. Cambridge University Press.

OwENS, B., VARKER, W.J., \& HUGHES, R.A. 1990. Lateral biostratigraphical consistency across the Mid-Carboniferous boundary in northern England. Courier Forschungsinstitut Senckenberg, 130, 237-244.

Posamentier, H.W., JerVey, M.T. \& Vail, P.R. 1988. Eustatic controls on clastic deposition 1 -conceptual framework. In: WiLgnUS, C.K., HaStings, C.G.St C., KendALL, H.W., 
Posamentier, H.W., Ross, C.A. \& VAn WAgOner, J.C. (eds). Sea-level changes: an integrated approach. Society of Economic Paleontologists and Mineralogists Special Publication, 42, 39-45.

RAMSBOTTOM, W.H.C. 1977. Major cycles of transgression and regression (mesothems) in the Namurian. Proceedings of the Yorkshire Geological Society, 41, 261-291.

RAMSBOTTOM, W.H.C. 1979. Rates of transgression and regression in the Carboniferous of NW Europe. Quarterly Journal of the Geological Society of London, 136, 147-154.

Riley, N.J., Claoué-Long, J.C., Higgins, A.C., Owens, B., Spears, A., Taylor, L., \& VARKER, W.J. 1995. Geochronometry and geochemistry of the European midCarboniferous boundary global stratotype proposal, Stonehead Beck, North Yorkshire, UK. Annales de la Société géologique de Belgique, 116, 275-289.

RIPPON, J.H. 1996. Sand body orientation, palaeoslope analysis and basin-fill implications in the Westphalian A-C of Great Britain. Journal of the Geological Society, London, 153, 881900 .

Roberts, J., Claoué-Long, J.C., Jones, P.J. \& Foster, C.B. 1995. SHRIMP zircon age control of Gondwanan sequences in Late Carboniferous and Early Permian Australia. In: DUNAY, R.E. \& HAILWOoD, E.A. (eds), Non-biostratigraphical Methods of Dating and Correlation. Geological Society Special Publication, 89, 145-174.

SpeArs, D.A. \& KanARis-Sotiriou, R. 1979. A geochemical and mineralogical investigation of some British and other European tonsteins. Sedimentology, 26, 407-425.

Spears, D.A., Kanaris-Sotiriou, R., Riley, N.J. \& Krause, P. 1999. Namurian bentonites in the Pennine Basin, UK - origin and magmatic affinities. Sedimentology, 46, 385-401.

Stephenson, M.H., Angiolini, L., Cózar, P., Jadoul, F., Leng, M.J., Millward, D. \& CHENERY, S. 2010. Northern England Serpukhovian (early Namurian) farfield responses to southern hemisphere glaciation. Journal of the Geological Society, 167, 1171-1184.

TRAPP, E. \& KaUfmanN, B. 2002. Hochpräzise U-Pb Datierungen von Paroklastika im Jungpaläozoikum. Neustadt: Schwerpunktprogram der deutschen Forschungsgemeinschaft DFG (SPP 1054), 18-19.

TREwIN, N.H. 1968. Potassium bentonites in the Namurian of Staffordshire and Derbyshire. Proceedings of the Yorkshire Geological Society, 37, 73-91. 
Tucker, M.E., Gallagher, J., \& Leng, M.J. 2009. Are beds in shelf carbonates millennialscale cycles? An example from the mid-Carboniferous of northern England. Sedimentary Geology, 214, 19-34.

Veevers, J.J. \& Powell, C.M. 1987. Late Paleozoic glacial episodes in Gondwanaland reflected in Transgressive-Regressive depositional sequences in Euramerica. Geological Society of America Bulletin, 98, 475-487.

WAters, C.N., Somerville, I.D., Jones, N.S. \& 16 others 2011. A revised Correlation of Carboniferous Rocks in the British Isles. Geological Society Special Report No. 26, London.

WAters, C.N., Chisholm, J.I., Benfield, A.C., \& O’Beirne, A.M. 2008. Regional evolution of a fluviodeltaic cyclic succession in the Marsdenian (Late Namurian Stage, Pennsylvanian) of the Central Pennine Basin, UK. . Proceedings of the Yorkshire Geological Society, 57, $1-28$.

WATERS, C.N. \& DAVIES, S.J. 2006. Carboniferous extensional basins, advancing deltas and coal swamps. In: BRENCHLEY, P.J. \& RAwson, P.F. (eds) The Geology of England and Wales. The Geological Society London (Second edition), 173-223.

Waters, C.N., Glover, B.W. \& Powell, J.H. 1994. Structural synthesis of S Staffordshire, UK: implications for the Variscan evolution of the Pennine Basin. Journal of the Geological Society London, 151, 697-713.

WignALL, P.B. 1987. A biofacies analysis of the Gastrioceras cumbriense Marine Band (Namurian) of the central Pennines. Proceedings of the Yorkshire Geological Society, 46, $111-121$. 


\section{Figure captions}

Fig. 1. Map showing the approximate extent of Namurian and Westphalian strata at crop, the subcrop of Westphalian strata and the main pre-Namurian structural features of the Pennine Basin, derived from Waters et al. (2011). The location of the Harewood and Holme Pierrepont boreholes, from which new dates have been acquired during this study, are shown. DHDerbyshire High, WG- Widmerpool Gulf.

Fig. 2. U-Pb data for samples BLL1976 and EH28155. A, conventional U-Pb concordia plot of zircons analysed from samples BLL1976 and EH28155. The grey band reflects the uncertainty in the ${ }^{238} \mathrm{U}$ and ${ }^{235} \mathrm{U}$ decay constants (Jaffey et al. 1971). B, plot of ${ }^{238} \mathrm{U} /{ }^{206} \mathrm{~Pb}$ dates for single zircon crystals analyses (same data as in Figure 2a). Dashed ellipses/bars represent analyses of zircon that are considered to be xenocrysts and/or inherited crystals that are disregarded in calculation of final date, whereas as undashed ellipses/bars represent the analyses used for calculation of the weighted mean final date (see text for discussion). Data point error ellipses/bars are $2 \sigma$.

Fig. 3. Distribution of ammonoid acme facies in early Namurian marine bands: a) Pendleian; b) early Arnsbergian; c) mid to late Arnsbergian; d) Chokierian; e) Alportian; f) early Kinderscoutian. Grey tone denotes marine band with maximum areal extent for each interval. Key for Incised Valleys, as for Figure 5.

Fig. 4. Distribution of ammonoid acme facies in late Namurian-Westphalian marine bands: a) mid to late Kinderscoutian; b) early Marsdenian; c) late Marsdenian; d) Yeadonian- $\mathrm{G}_{\mathrm{bb}} 1$ modified from Wignall (1987); e) Langsettian and f) Duckmantian-Bolsovian, in part based upon Calver $(1968,1969)$. Grey tone denotes marine band with maximum areal extent for each interval. Key for Incised Valleys, as for Figure 5.

Fig. 5. Magnitude and duration of sea-level oscillations. Sea-level maxima are estimated through the determination of maximum areal extent of acme ammonoid facies. Abbreviations for Westphalian marine bands: SMB Subcrenatum Marine Band; LMB Listeri Marine Band; AmMB Amaliae Marine Band; VMB Vanderbeckei Marine Band; HMB Haughton Marine Band; AMB Aegiranum Marine Band; CMB Cambriense Marine Band. For marine bands lacking ammonoid fauna the magnitude of sea-level is determined through the acme marine fauna, ranging from Estheria to brachiopod-bivalve facies. Sea-level minima are determined through the presence of incised valleys, with the magnitude recorded by the number of underlying marine bands removed beneath the sequence boundary. Sources for incised valleys are as follows: a) Rogerley Channel (Dunham 1990); b) Upper Howgate Edge channel (Martinsen et al. 1995); c) Red Scar Grit 
(Brandon et al. 1995); d) Lower Follifoot Grit (Martinsen 1993); e) Intra-H $\mathrm{H}_{1 \mathrm{a}}$ unconformity 776 (Owens et al. 1990); f) Upper Follifoot Grit (Martinsen 1993); g) Todmorden Grit/Kinderscout 777 Grit (Hampson 1997); h) Upper Kinderscout Grit (Hampson 1997); i) Midgley Grit (Brettle 778 2001); j) Ashover Grit/Roaches Grit (Jones \& Chisholm 1997; Church \& Gawthorpe 1994); k) 779 Chatsworth Grit (Waters et al. 2008); 1) Rough Rock (Church \& Gawthorpe 1994); m) 780 Crawshaw Sandstone (Hampson et al. 1997); n) Thornhill Rock (Lake 1999); o) Woolley Edge 781 Rock (Aitken et al. 1999); p) Oaks Rock (Lake 1999); q) Mexborough Rock (Aitken et al. 782 1999). Radiometric dates are from this study and estimated ages of stage boundaries are from 783 Davydov et al. (2010), with an imposed 400 ka long-duration eccentricity oscillation numbered 784 sequentially for each international stage: S Serpukhovian; B Bashkirian; M Moscovian. The 785 proposed four main glaciations are highlighted as grey bands. 
1 Nature and timing of Late Mississippian to Mid Pennsylvanian glacio-eustatic sea-level changes of the Pennine Basin, UK

Colin N. Waters ${ }^{1} *$ and Daniel J. Condon ${ }^{2}$

${ }^{1}$ British Geological Survey, Kingsley Dunham Centre, Keyworth, Nottingham, NG12 5GG

${ }^{2}$ NERC Isotope Geoscience Laboratory, British Geological Survey, Kingsley Dunham

7 Centre, Keyworth, Nottingham, NG12 5GG

*E-mail: cnw@bgs.ac.uk

\section{Online Supplemental Information}

\section{Zircon U-Pb ID-TIMS Methods}

Zircons were isolated from ca. 100 grams of bentonite layer (sample BLL1976) from the BGS Harewood Borehole section and ca. 100 grams of bentonite layer (sample EH28155) from the Holme Pierrepont Borehole section, using conventional mineral separation techniques. Prior to isotope dilution thermal ionization mass spectrometry (ID-TIMS) analyses zircons were subject to a modified version of the chemical abrasion technique (Mattinson 2005). For details of sample pre-treatment, dissolution and anion exchange chemistry see Sláma et al. (2008). U-Pb ID-TIMS analyses herein utilized the EARTHTIME ${ }^{205} \mathrm{~Pb}_{-}{ }^{233} \mathrm{U}-{ }^{235} \mathrm{U}$ (ET535) tracer solution. Measurements at the NERC Isotope Geosciences Laboratory were performed on a Thermo Triton TIMS. Pb analyses were measured in dynamic mode on a MassCom SEM detector and corrected for $0.14 \pm 0.04 \% / \mathrm{u}$. mass fractionation. Linearity and dead-time corrections on the SEM were monitored using repeated analyses of NBS 982, NBS 981 and U500. Uranium was measured in static Faraday mode on $10^{11} \mathrm{ohm}$ resistors or for signal intensities $<15 \mathrm{mV}$, in dynamic mode on the SEM detector. Uranium was run as the oxide and corrected for isobaric interferences with an ${ }^{18} \mathrm{O} /{ }^{16} \mathrm{O}$ composition of 0.00205 (IUPAC value and determined through direct measurement at $\mathrm{NIGL})$. U-Pb dates and uncertainties were calculated using the algorithms of Schmitz \& Schoene (2007) and $\mathrm{a}^{235} \mathrm{U} /{ }^{205} \mathrm{~Pb}$ ratio for ET535 of $100.18 \pm 0.1 \%$. All common $\mathrm{Pb}$ in the analyses was attributed to the blank and subtracted based on the isotopic composition and associated uncertainties analysed over time. The ${ }^{206} \mathrm{~Pb} /{ }^{238} \mathrm{U}$ ratios and dates were corrected 
for initial ${ }^{230} \mathrm{Th}$ disequilibrium using a $\mathrm{Th} / \mathrm{U}$ [magma] of $4 \pm 1$ applying the algorithms of Schärer (1984) resulting in an increase in the ${ }^{206} \mathrm{~Pb} /{ }^{238} \mathrm{U}$ dates of $\sim 100 \mathrm{kyr}$. Errors for U-Pb dates are reported in the following format: $\pm \mathrm{X}(\mathrm{Y})[\mathrm{Z}]$, where $\mathrm{X}$ is the internal or analytical uncertainty in the absence of all systematic error (tracer calibration and decay constants), Y includes the quadratic addition of tracer calibration error (using a conservative estimate of the $2 \sigma$ standard deviation of $0.1 \%$ for the $\mathrm{Pb} / \mathrm{U}$ ratio in the tracer), and $\mathrm{Z}$ includes the quadratic addition of both the tracer calibration error and additional ${ }^{238} \mathrm{U}$ decay constant errors of Jaffey et al. (1971). All analytical uncertainties are calculated at the $95 \%$ confidence interval. These ${ }^{238} \mathrm{U} /{ }^{206} \mathrm{~Pb}$ dates are traceable back to SI units via the gravimetric calibration of the EARTHTIME U-Pb tracer and the determination of the ${ }^{238} \mathrm{U}$ decay constant (Condon et al. 2007; Jaffey et al. 1971). The results for the analyses of samples BLL1976 and EH28155 are shown in Table 1.

\section{Zircon U-Pb ID-TIMS Results and Discussion}

Zircons separated from both bentonite samples BLL1976 and EH28155 were small $(<50 \mu \mathrm{m})$ with aspect ratios of $\sim 1.5$ to $\sim 3$. For sample BLL1976 seventeen fractions (single grains) were analysed. Relatively large uncertainties on ${ }^{207} \mathrm{~Pb} /{ }^{206} \mathrm{~Pb}$ dates ( $\sim 5$ to $50 \mathrm{Ma}$ ) limit the usefulness of concordance for assessing the accuracy of ${ }^{206} \mathrm{~Pb} /{ }^{238} \mathrm{U}$ and the potential for subtle $\mathrm{Pb}$-loss and/or incorporation of minor amounts of older material. ${ }^{206} \mathrm{~Pb} /{ }^{238} \mathrm{U}$ dates for sample BLL1976 between 311 and 334 Ma with a distinct population (defined by 11 of the 17) of concordant analyses yielding a weighted mean ${ }^{206} \mathrm{~Pb} /{ }^{238} \mathrm{U}$ date of $328.34 \pm$ $0.30(0.43)[0.55] \mathrm{Ma}$ (Mean square weighted deviation (95\% confidence level, MSWD = 2.2). ${ }^{206} \mathrm{~Pb} /{ }^{238} \mathrm{U}$ dates that are older than the main population are interpeted as reflecting the analyses of zircon ante-/xeno-crysts, and grains that are younger as reflecting Pb-loss (see below). The MSWD for this sample exceeds that expected for a single population (Wendt \& Carl 1991) indicating excess scatter. There are two possible explanations for this scatter: (1) residual Pb-loss in younger zircons (e.g., z6, z15 and z12); or (2) older zircon U/Pb dates (e.g., z4, z19, z22, zA2) reflect pre-eruptive crystalisation of zircon (i.e., ante-/xeno-crysts). The alternative interpretations, based upon statistically cohernt populations, result in weighted mean ${ }^{206} \mathrm{~Pb} /{ }^{238} \mathrm{U}$ dates that are $\sim 200 \mathrm{ka}$ older/youger than the weighted mean ${ }^{206} \mathrm{~Pb} /{ }^{238} \mathrm{U}$ date of $328.34 \pm 0.30 \mathrm{Ma}$, in part as the $95 \%$ confidence error of the weighted average multiplies the ' $2 \sigma$ internal' error by the square root of the MSWD therefore using the actual scatter of the data rather than the predicted scatter based upon the main population 
(Ludwig 1991). Thus, in the absence of any independent criteria for the exclusion of data points from the main population we interpret the weighted mean ${ }^{206} \mathrm{~Pb} /{ }^{238} \mathrm{U}$ date of $328.34 \pm$ $0.30(0.43)[0.55] \mathrm{Ma}$ as being the best estimate for the zircons of this sample and inferentially the age of bentonite at the sampled stratigraphic level. For sample EH28155 nine fractions (single grains) were analysed, and the resulting data are presented in Figure 2 of the paper. Two of the nine analyses produced U-Pb dates older than the constraint imposed by sample BLL 1976 (see above). The remaining seven analyses yielded ${ }^{206} \mathrm{~Pb} /{ }^{238} \mathrm{U}$ dates between 306 and $317 \mathrm{Ma}$ with a distinct population (defined by 4 of the 7) of anlyses yielding a weighted mean ${ }^{206} \mathrm{~Pb} /{ }^{238} \mathrm{U}$ date of $314.37 \pm 0.25(0.40)[0.53]{ }^{1} \mathrm{Ma}(\mathrm{MSWD}=1.07)$ which is interpreted as being the best estimate for the zircons of this sample. In both samples the $\mathrm{U} / \mathrm{Pb}$ dates that are older than the main population are interpeted as reflecting the analyses of zircon ante/xeno-crysts, and grains that are younger as reflecting Pb-loss. This interpretation is supported by consideration of biostratigraphical and geochronological constraints (e.g., Davydov et al. 2010) for this time interval and is typical for moderate- $n$ high-precision U-Pb (zircon) data sets obtained on primary air-fall ash beds (e.g., Davydov et al., 2010; Schoene et al. 2010).

\section{Ammonoid biostratigraphy}

Ammonoid biozones in the Namurian succession are defined by the first appearance of ammonoid taxa, with the base of the biozones coinciding with the bases of specific marine bands. Ammonoid evolution rates reached an acme during the Namurian, such that the majority of marine bands comprise a distinct ammonoid fauna. The Namurian ammonoid biostratigraphy was developed largely from studies within the Central Pennine Basin by Bisat (1924; 1928) and Bisat \& Hudson (1943), and later refined by Ramsbottom (1969; 1971). The scheme used for the Namurian in this study is derived from Riley et al. (1995). An ammonoid biozonation scheme has not been developed for the Westphalian, but key ammonoid-bearing marine bands have been used as marker beds to divide the cyclical Coal Measures lithofacies. The key marine bands, identified by Ramsbottom et al. (1978), are named after the diagnostic ammonoid species, replacing a plethora of local geographical names used historically. Correlation in the Westphalian is enhanced by the presence of an additional framework of marker marine bands that contain less diagnostic fauna, such as thinshelled ammonoids (Anthracoceras), marine bivalves (Dunbarella), brachiopods (Lingula) 
and crustacea (Ostracodes, Estheria). Few such marine marker bands, entirely devoid of ammonoid fauna across the basin, are recognized in the Namurian succession.

\section{Calculation of areal extent of marine bands}

Ammonoid-bearing marine band locations, either from surface exposures or borehole samples, were determined by a comprehensive trawl of BGS palaeontological registers, BGS memoirs and technical reports and scientific publications, too many to reference individually. Marine band locations were used in the study only where ammonoids were described, representing the acme fauna, and for which the marine band attribution was unequivocal. It was decided that the recognition of marine faunal facies within the Namurian succession, as carried out for the Westphalian by Calver $(1968,1969)$, was beyond the scope of this study.

Table 2 shows the location and ammonoid assemblages used to compile the distribution maps. The described location is that given in registers or publications, presented without modification to show the basis by which locations were determined. Borehole locations and logs, available from the BGS Single Onshore Borehole Index (SOBI) database, were used to check the attribution of the marine bands. The British National Grid of surface locations was determined in the majority of cases by comparing the description of the locality to BGS fieldslips and published 1:10,560- or 1:10,000-scale maps which showed the location of the fossil locality. This also provided a means of confirming or determining from which marine band the sample was collected. If marine band identification was equivocal it was not included in the study. This is in particular relevant to marine bands present in great thicknesses of mudstone, for example in the Bowland Shale Formation, where correlation of distinct marine bands can be more uncertain. As the identification of marine band nomenclature is dependent on recognition of the first incoming of certain taxa, it can be difficult to confirm the first appearance unless a sequential succession of several marine bands are studied in a single section, which is relatively unusual in surface sections. Within the Millstone Grit Group, the cyclic nature of sedimentation means that marine bands commonly rest upon sandstones, with significant thicknesses between flooding events. This makes correlation of individual marine bands over large distances comparatively easy, with the relationship of specific marine bands to named sandstones well established. As a consequence of this study it has been possible to compile typical ammonoid assemblage lists for each marine band, something not previously published systematically. In Table 2 the faunal list is that which appears in the source register or literature. A modern reinterpretation 
126 of these faunal lists appears in Tables 2 to 3 in the publication. However, it is important to 127 realize that none of the specimens, many of which will be stored at BGS Keyworth, were 128 examined during this study to confirm the original identifications.

129 The distribution of the ammonoid facies in the Westphalian succession were previously 130 constrained by Calver $(1968,1969)$ and these envelopes were used in this study, with 131 modification where samples listed in Table 2 indicated the need to extend the extent of the envelope. In many cases this resulted from borehole data from the eastern part of the basin, acquired after Calver's studies.

134 For each marine band, the position of the ammonoid localities were presented using ArcGIS 135 software, an envelope was drawn around the locations and the areal extent of the envelope 136 calculated. To some extent, an understanding of the geology of the basin was required to determine the extent that the area between locations could be assumed to still be ammonoidbearing. In particular, envelopes were not extrapolated across areas where no data were available, either through the marine band being too deeply buried to be proved by boreholes, 140 or absent through removal by erosion. 
The regional chronostratigraphy was initially scaled against absolute time using the two dates acquired during this study and the additional constraints for the age of the base of the Serpukhovian and Bashkirian, derived from Davydov et al. (2010). By dividing each of the age ranges (base Pendleian to early Arnbergian, early Arnbergian to Chokierian and Chokierian to early Bolsovian) by the number of recognized flooding surfaces within each interval it was possible to recognize the average cycle duration. However, consideration of just peak flooding events and Type 1 unconformities suggested that a $\sim 400$ kyr eccentricity frequency persisted throughout the study interval, a duration consistent with findings from other international studies. On this basis the Serpukhovian, Bashkirian and lower part of the Moscovian stages were subdivided into $400 \mathrm{kyr}$ cycles, numbered S1 to S17, B1 to B20 and M1 to M3, respectively. Peak flooding events were then aligned to each of the cycles. Where this proved not possible for the Mid to Late Arnsbergian succession because of too few flooding events, it was decided to take an arbitrary position of spacing equally the $E_{2 b} 3$ and $\mathrm{E}_{2 \mathrm{c}} 1$ flooding events.

The magnitude of sea-level oscillations is presented using three distinct scales. The areal extent of ammonoid facies is presented as a linear scale of 1000 's $\mathrm{Km}^{2}$. Non-ammonoid bearing flooding events were incorporated into the analysis by indicating the acme marine facies described within the Pennine Basin. The order presented of Estheria, Foraminifera, Lingula and brachiopod-bivalve facies, indicates increasing marine influence (Calver 1968). The absolute magnitude of sea-level fall associated with many of the Type 1 unconformities is unrecorded, whereas the number of cycles removed by erosion was determinable from publications describing these erosional surfaces. Again, this does not provide absolute magnitudes of sea-level falls, but is indicative of the relative significance of these events. It is important to realize that the resultant figure, using three different scales provides a means to visualize relative magnitudes of sea-level fluctuation but cannot be used to an oscillatory sealevel curve. 


\section{References}

BISAT, W.S. 1924. The Carboniferous goniatites of the north of England and their zones. Proceedings of the Yorkshire Geological Society, 20, 40-124.

BISAT, W.S. 1928. The Carboniferous goniatite zones of England and their continental equivalents. Congrès pour l'Avancement des Etudes de Stratigraphie Carbonifère, Compte Rendu, Heerlen 1927, 117-133.

BisAT, W.S. \& HUDSON, R.G.S. 1943. The Lower Reticuloceras (R1) Goniatite succession in the Namurian of the north of England. Proceedings of the Yorkshire Geological Society, 24, 383-440.

CAlver, M.A. 1968. Distribution of Westphalian marine faunas in northern England and adjoining areas. Proceedings of the Yorkshire Geological Society, 37, 1-72.

CAlver, M.A. 1969. Westphalian of Britain. Compte Rendu 6e Congrès Internationale Stratigraphie et Géologie Carbonifère, Sheffield, 1967, I, 233-254.

Condon, D., Schoene, B., Bowring, S., Parrish, R., Mclean, N., Noble, S. \& Crowley, Q. 2007. EARTHTIME; isotopic tracers and optimized solutions for high-precision U-Pb IDTIMS geochronology. Eos, Transactions, American Geophysical Union, 88.

Crowley, J.L., Schoene, B. \& Bowring, S.A. 2007. U-Pb Dating of Zircon in the Bishop Tuff at the Millennial Scale. Geology, 35, 1123-1126.

Davydov, V.I., Crowley, J.L., Schmitz, M.D., \& Poletaev, V.I. 2010. High-precision U$\mathrm{Pb}$ zircon age calibration of the global Carboniferous time scale and Milankovitch band cyclicity in the Donets Basin, eastern Ukraine. Geochemistry Geophysics Geosystems, 11, Q0AA04, doi:10.1029/2009GC002736.

Jaffey, A.H., Flynn, K.F., Glendenin, L.E., Bentley, W.C. \& Essling, A.M. 1971. Precision Measurement of Half-Lives and Specific Activities of ${ }^{235} \mathrm{U}$ and ${ }^{238} \mathrm{U}$. Physical Review C, 4, 1889-1906.

LUDWIG, K.R. 1991. Isoplot - a plotting and regression program for radiogenic isotope data: USGS Open File Report, 91-445

Mattinson, J M. 2005. Zircon U-Pb chemical abrasion ("CA-TIMS") method: Combined annealing and multi-step partial dissolution analysis for improved precision and accuracy of zircon ages. Chemical Geology, 220, 47-66. 
Ramsbottom, W.H.C. 1969. The Namurian of Britain. Compte Rendue 6 ème Congrès International de Stratigraphie et de Geologie du Carbonifère, Sheffield, 1967.

RAMSBOTTOM, W.H.C. 1971. Palaeogeography and goniatite palaeogeography in the Namurian and early Westphalian. Compte Rendue, 6 ème Congrès International de Stratigraphie et de Geologie du Carbonifère, Sheffield, 1967, 1396-1399.

Ramsbottom, W.H.C., Calver, M.A., Eagar, R.M.C., Hodson, F., Holliday, D.W., StubBlefield, C.J. \& Wilson, R.B. 1978. A correlation of Silesian rocks in the British Isles. Special Report of the Geological Society of London, 10.

Riley, N.J., Claoué-Long, J.C., Higgins, A.C., Owens, B., Spears, A., Taylor, L., \& VARKER, W.J. 1995. Geochronometry and geochemistry of the European midCarboniferous boundary global stratotype proposal, Stonehead Beck, North Yorkshire, UK. Annales de la Société géologique de Belgique, 116, 275-289.

SCHÄRER, U., 1984, The effect of initial ${ }^{230} \mathrm{Th}$ disequilibrium on young U-Pb ages: the Makalu case, Himalaya. Earth and Planetary Science Letters, 67 (2), 191-204.

Schoene, B., Guex, J., Bartolini, A., Schaltegger, U., \& Blackburn, T.J., 2010, Correlating the end-Triassic mass extinction and flood basalt volcanism at the $100 \mathrm{ka}$ level. Geology, 38, 387-390.

Schmitz, M.D. \& Schoene, B. 2007. Derivation of isotope ratios, errors, and error correlations for $\mathrm{U}-\mathrm{Pb}$ geochronology using ${ }^{205} \mathrm{~Pb}-{ }^{235} \mathrm{U}-\left({ }^{233} \mathrm{U}\right)$-spiked isotope dilution thermal ionization mass spectrometric data. Geochemistry Geophysics Geosystems, 8, 20pp.

Sláma, J., Kosler, J., Condon, D.J., Crowley, J.L., Gerdes, A., Hanchar, J.M., Horstwood, M.S. A., Morris, G.A., Nasdala, L., Norberg, N., Schaltegger, U., Schoene, B., Tubrett, M. N., \& Whitehouse, M. J. 2008. Plesovice zircon; a new natural reference material for U-Pb and $\mathrm{Hf}$ isotopic microanalysis. Chemical Geology, 249, 1-35.

WENDT, I. \& CARL, C. 1991. The statistical distribution of the mean squared weighted deviation. Chemical Geology, Isotope Geoscience section, 86, 275-285 
Table 1. U-Th- $\mathrm{Pb}$ isotopic data

\begin{tabular}{|c|c|c|c|c|c|c|c|c|c|c|c|c|c|c|c|c|c|c|c|c|}
\hline \multirow[b]{2}{*}{$\begin{array}{l}\text { Sample } \\
\text { (a) }\end{array}$} & \multicolumn{6}{|c|}{ Compositional Parameters } & \multicolumn{8}{|c|}{ Radiogenic Isotope Ratios } & \multicolumn{6}{|c|}{ Isotopic Ages } \\
\hline & $\begin{array}{l}\frac{T h}{U} \\
\text { (b) }\end{array}$ & $\begin{array}{c}{ }^{206} \mathrm{~Pb}^{*} \\
\mathrm{x} 10^{-13} \mathrm{~mol} \\
(\mathrm{c})\end{array}$ & $\begin{array}{c}\mathrm{mol} \% \\
{ }^{206} \mathrm{~Pb}^{*} \\
(\mathrm{c}) \\
\end{array}$ & $\begin{array}{l}\mathrm{Pb}^{*} \\
\mathrm{~Pb}_{\mathrm{c}} \\
(\mathrm{c}) \\
\end{array}$ & $\begin{array}{l}\mathrm{Pb}_{\mathrm{c}} \\
(\mathrm{pg}) \\
(\mathrm{c}) \\
\end{array}$ & $\begin{array}{c}\frac{{ }^{206} \mathrm{~Pb}}{{ }^{204} \mathrm{~Pb}} \\
\text { (d) } \\
\end{array}$ & $\begin{array}{c}\frac{{ }^{208} \mathrm{~Pb}}{{ }^{206} \mathrm{~Pb}} \\
(\mathrm{e}) \\
\end{array}$ & $\begin{array}{c}\frac{{ }^{207} \mathrm{~Pb}}{{ }^{206} \mathrm{~Pb}} \\
(\mathrm{e}) \\
\end{array}$ & $\begin{array}{c}\% \text { err } \\
\text { (f) }\end{array}$ & $\begin{array}{c}\frac{{ }^{207} \mathrm{~Pb}}{{ }^{235} \mathrm{U}} \\
(\mathrm{e}) \\
\end{array}$ & $\begin{array}{c}\% \text { err } \\
\text { (f) }\end{array}$ & $\begin{array}{l}\frac{{ }^{206} \mathrm{~Pb}}{{ }^{238} \mathrm{U}} \\
(\mathrm{e}) \\
\end{array}$ & $\begin{array}{c}\% \text { err } \\
\text { (f) }\end{array}$ & $\begin{array}{l}\text { corr. } \\
\text { coef. }\end{array}$ & $\begin{array}{c}\frac{{ }^{207} \mathrm{~Pb}}{{ }^{206} \mathrm{~Pb}} \\
(\mathrm{~g}) \\
\end{array}$ & $\begin{array}{l} \pm \\
\text { (f) } \\
\end{array}$ & $\begin{array}{c}\frac{{ }^{207} \mathrm{~Pb}}{{ }^{235} \mathrm{U}} \\
(\mathrm{g}) \\
\end{array}$ & $\begin{array}{l} \pm \\
\text { (f) } \\
\end{array}$ & $\begin{array}{l}\frac{{ }^{206} \mathrm{~Pb}}{{ }^{238} \mathrm{U}} \\
(\mathrm{g}, \mathrm{h}) \\
\end{array}$ & $\begin{array}{l} \pm \\
\text { (f) }\end{array}$ \\
\hline \multicolumn{21}{|l|}{ EH-28155 } \\
\hline $\mathrm{z} 2$ & 0.407 & 0.4794 & $98.68 \%$ & 22 & 0.53 & 1378 & 0.128 & 0.05276 & 0.27 & 0.3666 & 0.34 & 0.05040 & 0.10 & 0.740 & 317.6 & 6.2 & 317.14 & 0.92 & 317.07 & 0.31 \\
\hline $\mathrm{z} 3$ & 0.379 & 0.4504 & $98.43 \%$ & 18 & 0.60 & 1159 & 0.120 & 0.05271 & 0.66 & 0.3634 & 0.70 & 0.05000 & 0.17 & 0.315 & 315.7 & 15.1 & 314.73 & 1.88 & 314.60 & 0.52 \\
\hline $\mathrm{z} 4$ & 0.213 & 0.3503 & $97.99 \%$ & 14 & 0.60 & 904 & 0.067 & 0.05254 & 0.38 & 0.3606 & 0.45 & 0.04977 & 0.12 & 0.650 & 308.3 & 8.7 & 312.63 & 1.21 & 313.22 & 0.38 \\
\hline $\mathrm{z} 5$ & 0.362 & 0.5413 & $98.74 \%$ & 23 & 0.57 & 1446 & 0.115 & 0.05272 & 0.26 & 0.3629 & 0.33 & 0.04993 & 0.12 & 0.708 & 316.0 & 6.0 & 314.39 & 0.90 & 314.17 & 0.36 \\
\hline z6 & 0.319 & 0.1435 & $97.09 \%$ & 10 & 0.36 & 625 & 0.100 & 0.05287 & 0.62 & 0.3863 & 0.70 & 0.05300 & 0.18 & 0.545 & 322.6 & 14.1 & 331.69 & 1.97 & 333.00 & 0.57 \\
\hline zA6 & 0.357 & 0.2455 & $95.99 \%$ & 7 & 0.85 & 454 & 0.112 & 0.05222 & 0.82 & 0.3601 & 0.91 & 0.05001 & 0.20 & 0.514 & 294.5 & 18.7 & 312.30 & 2.43 & 314.69 & 0.62 \\
\hline zA7 7 & 0.470 & 0.1401 & $90.22 \%$ & 3 & 1.26 & 186 & 0.145 & 0.05120 & 2.57 & 0.3525 & 2.72 & 0.04994 & 0.32 & 0.498 & 249.2 & 59.2 & 306.63 & 7.20 & 314.23 & 0.99 \\
\hline $\mathrm{zA} 8$ & 0.345 & 0.5371 & $91.46 \%$ & 3 & 4.16 & 213 & 0.109 & 0.05346 & 1.04 & 0.3958 & 1.14 & 0.05370 & 0.24 & 0.534 & 347.7 & 23.4 & 338.59 & 3.29 & 337.27 & 0.78 \\
\hline $\mathrm{zA} 9$ & 0.261 & 0.1667 & $90.37 \%$ & 3 & 1.47 & 189 & 0.081 & 0.05171 & 1.85 & 0.3475 & 1.99 & 0.04874 & 0.20 & 0.704 & 271.7 & 42.4 & 302.82 & 5.21 & 306.87 & 0.61 \\
\hline \multicolumn{21}{|l|}{ BLL 1976} \\
\hline $\mathrm{z} 2$ & 1.464 & 0.3195 & $98.10 \%$ & 20 & 0.51 & 960 & 0.463 & 0.05305 & 0.39 & 0.3821 & 0.45 & 0.05225 & 0.12 & 0.638 & 330.4 & 8.8 & 328.61 & 1.28 & 328.35 & 0.38 \\
\hline $\mathrm{z} 4$ & 1.771 & 0.1298 & $94.23 \%$ & 7 & 0.66 & 315 & 0.555 & 0.05255 & 1.40 & 0.3793 & 1.51 & 0.05235 & 0.21 & 0.564 & 309.1 & 32.0 & 326.51 & 4.22 & 328.96 & 0.67 \\
\hline $\mathrm{z} 5$ & 1.482 & 0.3720 & $94.55 \%$ & 7 & 1.78 & 334 & 0.463 & 0.05239 & 1.18 & 0.3759 & 1.28 & 0.05204 & 0.17 & 0.630 & 302.0 & 26.9 & 324.01 & 3.55 & 327.08 & 0.54 \\
\hline $\mathrm{z6}$ & 1.457 & 0.7789 & $98.34 \%$ & 22 & 1.09 & 1093 & 0.460 & 0.05296 & 0.36 & 0.3807 & 0.43 & 0.05213 & 0.13 & 0.618 & 326.8 & 8.2 & 327.55 & 1.19 & 327.65 & 0.42 \\
\hline $\mathrm{z} 12$ & 1.542 & 0.0831 & $94.72 \%$ & 7 & 0.38 & 345 & 0.488 & 0.05316 & 1.13 & 0.3826 & 1.24 & 0.05221 & 0.23 & 0.530 & 335.3 & 25.7 & 328.98 & 3.48 & 328.10 & 0.73 \\
\hline z14 & 1.355 & 0.0874 & $92.38 \%$ & 4 & 0.60 & 239 & 0.430 & 0.05326 & 1.67 & 0.3838 & 1.80 & 0.05227 & 0.26 & 0.552 & 339.5 & 37.7 & 329.85 & 5.06 & 328.48 & 0.84 \\
\hline $\mathrm{z} 15$ & 1.319 & 0.4603 & $99.04 \%$ & 38 & 0.37 & 1896 & 0.417 & 0.05300 & 0.24 & 0.3810 & 0.58 & 0.05214 & 0.51 & 0.915 & 328.3 & 5.3 & 327.79 & 1.63 & 327.71 & 1.63 \\
\hline z16 & 0.104 & 0.2838 & $98.46 \%$ & 17 & 0.37 & 1179 & 0.033 & 0.05302 & 0.33 & 0.3820 & 0.40 & 0.05226 & 0.12 & 0.651 & 328.8 & 7.5 & 328.49 & 1.11 & 328.45 & 0.39 \\
\hline z17 & 1.267 & 0.1359 & $93.68 \%$ & 5 & 0.76 & 288 & 0.398 & 0.05254 & 1.28 & 0.3748 & 1.39 & 0.05173 & 0.20 & 0.593 & 308.8 & 29.1 & 323.19 & 3.84 & 325.19 & 0.65 \\
\hline z18 & 1.447 & 0.1733 & $97.58 \%$ & 15 & 0.36 & 754 & 0.454 & 0.05262 & 0.55 & 0.3805 & 0.62 & 0.05244 & 0.15 & 0.573 & 311.9 & 12.5 & 327.37 & 1.73 & 329.56 & 0.48 \\
\hline z19 & 1.145 & 0.1573 & $97.23 \%$ & 12 & 0.37 & 658 & 0.359 & 0.05259 & 0.56 & 0.3793 & 0.64 & 0.05231 & 0.18 & 0.571 & 310.6 & 12.8 & 326.54 & 1.80 & 328.78 & 0.58 \\
\hline z21 & 1.472 & 0.1358 & $95.68 \%$ & 8 & 0.51 & 421 & 0.464 & 0.05289 & 0.97 & 0.3830 & 1.05 & 0.05253 & 0.18 & 0.541 & 323.5 & 21.9 & 329.24 & 2.96 & 330.06 & 0.59 \\
\hline $\mathrm{z} 22$ & 1.552 & 0.2240 & $94.98 \%$ & 7 & 0.98 & 363 & 0.488 & 0.05274 & 0.95 & 0.3805 & 1.06 & 0.05233 & 0.26 & 0.516 & 317.2 & 21.6 & 327.42 & 2.96 & 328.86 & 0.85 \\
\hline $\mathrm{zA} 1$ & 1.515 & 0.1162 & $96.44 \%$ & 10 & 0.36 & 511 & 0.478 & 0.05303 & 0.69 & 0.3886 & 0.77 & 0.05315 & 0.15 & 0.608 & 329.9 & 15.8 & 333.38 & 2.20 & 333.89 & 0.48 \\
\hline $\mathrm{zA} 2$ & 1.535 & 0.0427 & $93.65 \%$ & 6 & 0.24 & 287 & 0.486 & 0.05265 & 2.45 & 0.3591 & 2.56 & 0.04946 & 0.34 & 0.387 & 313.4 & 55.7 & 311.51 & 6.87 & 311.25 & 1.05 \\
\hline $\mathrm{zA} 3$ & 1.372 & 0.0706 & $96.95 \%$ & 12 & 0.18 & 596 & 0.435 & 0.05325 & 0.73 & 0.3845 & 0.83 & 0.05236 & 0.26 & 0.524 & 339.1 & 16.5 & 330.31 & 2.33 & 329.06 & 0.82 \\
\hline $\mathrm{zA} 4$ & 1.404 & 0.0423 & $93.74 \%$ & 6 & 0.23 & 291 & 0.444 & 0.05313 & 1.35 & 0.3830 & 1.47 & 0.05228 & 0.32 & 0.480 & 334.0 & 30.6 & 329.23 & 4.15 & 328.56 & 1.04 \\
\hline
\end{tabular}


(a) z1, z2 etc. are labels for fractions composed of single zircon grains or fragments; all fractions annealed and chemically abraded after Mattinson (2005).

(b) Model $\mathrm{Th} / \mathrm{U}$ ratio calculated from radiogenic ${ }^{208} \mathrm{~Pb} /{ }^{206} \mathrm{~Pb}$ ratio and ${ }^{207} \mathrm{~Pb} /{ }^{235} \mathrm{U}$ age.

(c) $\mathrm{Pb}^{*}$ and $\mathrm{Pbc}$ represent radiogenic and common $\mathrm{Pb}$, respectively; mol $\%{ }^{206} \mathrm{~Pb}^{*}$ with respect to radiogenic, blank and initial common $\mathrm{Pb}$.

(d) Measured ratio corrected for spike and fractionation only.

(e) Corrected for fractionation, spike, and common $\mathrm{Pb}$; up to 2 pg of common $\mathrm{Pb}$ was assumed to be procedural blank: ${ }^{206} \mathrm{~Pb} /{ }^{204} \mathrm{~Pb}=18.60 \pm 0.80 \%$; ${ }^{207} \mathrm{~Pb} /{ }^{204} \mathrm{~Pb}=15.69 \pm 0.32 \% ;{ }^{208} \mathrm{~Pb} /{ }^{204} \mathrm{~Pb}=38.51 \pm 0.74 \%$ (all uncertainties 1 -sigma). Excess over blank was assigned to initial common $\mathrm{Pb}$.

(f) Errors are 2-sigma, propagated using the algorithms of Schmitz \& Schoene

(2007).

(g) Calculations are based on the decay constants of Jaffey et al. (1971). ${ }^{206} \mathrm{~Pb} /{ }^{238} \mathrm{U}$ and ${ }^{207} \mathrm{~Pb} /{ }^{206} \mathrm{~Pb}$ ages corrected for initial disequilibrium in ${ }^{230} \mathrm{Th} /{ }^{238} \mathrm{U}$ using Th/U $[\mathrm{magma}]=3$ using the algorithms of Schärer (1984).

(h) dates in bold are those included in weighted mean calculations. See text for discussion. 
Table 2 Biostratigraphical data used to compile the distribution of marine bands

\begin{tabular}{|c|c|c|c|}
\hline LOCALITY & EASTING & $\begin{array}{l}\text { NORTHIN } \\
\text { G }\end{array}$ & AMMONOIDS \\
\hline \multicolumn{4}{|l|}{ Emstites (Cravenoceras) leion Marine Band (E1a1) } \\
\hline Whinney Gill Reservoir,Skipton,Yorkshire & 399900 & 451000 & Cravenoceras leion \\
\hline River Ribble,Dinckley,Lancs & 368640 & 436520 & Cravenoceras leion \\
\hline $\begin{array}{l}\text { Harry Wall Gill - in stream bed W of Station - } \\
\text { Bolton Abbey. }\end{array}$ & 405830 & 452740 & Cravenoceras leion \\
\hline Bramley Farm - Bleaklow - Derbys. & 424300 & 373400 & Cravenoceras leion \\
\hline $\begin{array}{l}\text { Carla Beck - S of Rectory Carleton - Skipton - } \\
\text { Yorks. }\end{array}$ & 397600 & 448100 & Cravenoceras leion \\
\hline $\begin{array}{l}\text { Audley Beck - Pendleton - nr Clitheroe - } \\
\text { Lancs. }\end{array}$ & 376100 & 438500 & Cravenoceras leion \\
\hline Croasdale Beck - NNW of Slaidburn & 369680 & 455510 & Cravenoceras leion \\
\hline Whinney Hill Brickpits,Skipton & 400100 & 451100 & Cravenoceras leion \\
\hline $\begin{array}{l}\text { Longstone Station - disused Railway cutting } \\
\text { West of Longstone Station. }\end{array}$ & 419530 & 371120 & Cravenoceras leion \\
\hline Greenleighton Quarry,9miles NNW of Belsay & 403400 & 591700 & Cravenoceras leion \\
\hline Bleaklow Mining Company - Exposure. & 423000 & 373420 & Cravenoceras leion \\
\hline Alport Boring,near Alport & 413610 & 391050 & Cravenoceras leion \\
\hline Hind Clough, Forest of Bowland & 364400 & 453300 & Cravenoceras leion \\
\hline Southwest of The Hill & 406400 & 357300 & Cravenoceras leion \\
\hline Railway cutting near Thornbridge Hall & 419530 & 371130 & Cravenoceras leion \\
\hline Raper Mine & 421690 & 365230 & Cravenoceras leion \\
\hline Bowers Hall BH SK26SW/46 & 423490 & 364560 & Cravenoceras leion \\
\hline Mootlaw Quarry, Matfen & 402400 & 575000 & Cravenoceras aff. lineolatum \\
\hline Light Clough, Pendle Hill & 375160 & 437640 & Cravenoceras leion \\
\hline Downs Gill, Coverhead & 399000 & 476500 & ?Cravenoceras sp. \\
\hline Roosecote $\mathrm{BH}$ & 323040 & 468660 & Cravenoceras sp. \\
\hline Darnbrook Beck & 387420 & 471710 & Cravenoceras leion \\
\hline Cominco Borehole S3 & 386010 & 463500 & $\begin{array}{l}\text { Cravenoceras leion, Euomorphoceras } \\
\text { tornquisti }\end{array}$ \\
\hline Eshton Beck & 394220 & 455730 & Cravenoceras cf. leion \\
\hline Cowside Beck & 385650 & 466370 & Cravenoceras cf. leion \\
\hline Daw Haw Beck & 385100 & 466460 & Cravenoceras leion \\
\hline $\begin{array}{l}\text { NE of Lower House, near Scotch Green, } \\
\text { Inglewhite }\end{array}$ & 353640 & 440780 & Cravenoceras cf. leion \\
\hline Inglewhite & 354550 & 439030 & Cravenoceras sp. \\
\hline East of Hall Trees Farm, west of Chipping & 360710 & 442200 & Cravenoceras leion \\
\hline $200 \mathrm{~m}$ north of Higher Core, Bowland Fells & 359240 & 444370 & Cravenoceras leion \\
\hline White Fold, near Longridge Fold & 362180 & 439340 & Cravenoceras sp. \\
\hline Little Mearley Clough & 377900 & 441400 & Cravenoceras leion \\
\hline Higher Laithe Plantation & 386000 & 445300 & Cravenoceras leion \\
\hline Edale $\mathrm{BH}$ & 410780 & 384930 & $\begin{array}{l}\text { Cravenoceras leion, Eumorphoceras } \\
\text { tornquisti }\end{array}$ \\
\hline Castleton $\mathrm{BH}$ & 414100 & 382930 & $\begin{array}{l}\text { Cravenoceras leion, Eumorphoceras } \\
\text { sp. }\end{array}$ \\
\hline Hope cement works BH, Salter Barn & 416780 & 382280 & $\begin{array}{l}\text { Cravenoceras leion, Eumorphoceras } \\
\text { sp. }\end{array}$ \\
\hline Calow No $1 \mathrm{BH}$ & 440860 & 370410 & $\begin{array}{l}\text { Cravenoceras cf. leion, Eumorphoceras } \\
\text { sp. }\end{array}$ \\
\hline Disused railway cutting near Waterhouses & 407530 & 349560 & 8 bands \\
\hline Bullclough & 406030 & 355020 & Cravenoceras sp. \\
\hline Ford, R. Hamps & 406600 & 353700 & Cravenoceras leion \\
\hline SW of Parwich & 417680 & 354060 & Cravenoceras leion \\
\hline Lees Farm BH & 418180 & 350160 & $\begin{array}{l}\text { Cravenoceras leion, C. sp., } \\
\text { Eumorphoceras involutum }\end{array}$ \\
\hline Farnah House, Duffield & 432430 & 343280 & Cravenoceras cf. leion \\
\hline Duffield BH & 434280 & 342170 & Cravenoceras. Sp., C. leion \\
\hline Widmerpool No. 1 BH SK62NW/1 & 463660 & 329580 & $\begin{array}{l}\text { ?Cravenoceras. sp., C. cf. leion, C. cf. } \\
\text { malhamense, Eumorphoceras sp., E. } \\
\text { pseudobilingue, Girtyoceras }\end{array}$ \\
\hline \multicolumn{4}{|l|}{ Cravenoceras brandoni Marine Band (E1b1) } \\
\hline Burn Fell & 367800 & 453100 & Cravenoceras brandoni \\
\hline \multicolumn{4}{|l|}{ Tumulites pseudobilinguis Marine Band (E1b2) } \\
\hline Ramshaw Beck - Skipton & 397500 & 448600 & aff Eumorphoceras pseudobilingue \\
\hline Little Mearley Clough, Pendle, Lancs & 378500 & 441100 & Eumorphoceras pseudobilingue \\
\hline
\end{tabular}




\begin{tabular}{|c|c|c|c|}
\hline Cow Close Sike, Malham & 390810 & 462100 & Eumorphoceras pseudobilingue \\
\hline Alport BH, Alport Castle's Farm, Glossop & 413612 & 391055 & Eumorphoceras pseudobilingue \\
\hline LOCALITY & EASTING & $\begin{array}{l}\text { NORTHIN } \\
\text { G }\end{array}$ & AMMONOIDS \\
\hline \multicolumn{4}{|c|}{ Tumulites pseudobilinguis Marine Band (E1b2) Continued } \\
\hline Studforth Gill - Tosside - SW of Settle & 377340 & 457500 & Eumorphoceras pseudobilingue $\mathrm{C}$ \\
\hline Croasdale Beck - NNW of Slaidburn - Yorks & 369680 & 455510 & Eumorphoceras pseudobilingue \\
\hline Jenny Gill, 30yds from bottom fence, Skipton. & 400440 & 451110 & Eumorphoceras pseudobilingue \\
\hline Whinney Gill Quarry - Skipton & 399900 & 451000 & Eumorphoceras pseudobilingue \\
\hline Swarth Beck, Kellet Park Wood & 353060 & 470770 & Tumulites pseudobilinguis \\
\hline Burn Fell & 367800 & 453100 & Tumulites pseudobilinguis \\
\hline $\begin{array}{l}\text { Skibeden Beck, Bullion 840' OD, Parkers Hull } \\
\text { - Skipton }\end{array}$ & 402200 & 451500 & Eumorphoceras pseudobilingue \\
\hline Southwest of Warslow Hall & 408620 & 359250 & Eumorphoceras pseudobilingue \\
\hline Isingdale Beck, east of Linton & 401000 & 463000 & Eumorphoceras pseudobilingue \\
\hline $\begin{array}{l}\text { North bank of R. Wharfe, opposite Linton } \\
\text { church }\end{array}$ & 400500 & 463028 & Eumorphoceras pseudobilingue \\
\hline Grimwith Reservoir & 406000 & 464000 & Eumorphoceras pseudobilingue \\
\hline Roosecote $\mathrm{BH}$ & 323040 & 468660 & Eumorphoceras pseudobilingue \\
\hline Hare Clough Beck, Catlow & 370470 & 457150 & Eumorphoceras pseudobilingue \\
\hline Hollow Gill Wood, south of Rathmell & 380040 & 458510 & Eumorphoceras pseudobilingue \\
\hline Tranlands Beck SW of Malham & 389460 & 462360 & Eumorphoceras pseudobilingue \\
\hline Tributary of Tranlands Beck & 388460 & 462350 & Eumorphoceras pseudobilingue \\
\hline Crimple Beck BH & 427280 & 451860 & Tumulites pseudobilinguis \\
\hline River Brock, Walmsley Bridge to Brock Bottom & 353720 & 441660 & Tumulites cf. pseudobilinguis \\
\hline Right bank Fiendsdale Water & 359630 & 449350 & Tumulites pseudobilinguis \\
\hline White Fold, near Longridge Fold & 362180 & 439340 & Tumulites sp. \\
\hline R. Ribble west of Dinckley Hall & 368640 & 436520 & Eumorphoceras pseudobilingue \\
\hline Butler Clough & 372600 & 435400 & Eumorphoceras pseudobilingue \\
\hline Light Clough & 375108 & 437708 & Eumorphoceras pseudobilingue \\
\hline Deep Clough & 380900 & 440300 & Eumorphoceras pseudobilingue \\
\hline Weets Hollow & 385900 & 445100 & Eumorphoceras pseudobilingue \\
\hline Castleton $\mathrm{BH}$ & 414100 & 382930 & Eumorphoceras pseudobilingue \\
\hline River Noe, 700 yds N38W of Manor House & 410630 & 384950 & Eumorphoceras pseudobilingue \\
\hline Calow No $1 \mathrm{BH}$ & 440860 & 370410 & Eumorphoceras pseudobilingue ss. \& C \\
\hline WSW of Knockerdown & 422810 & 352010 & Eumorphoceras pseudobilingue \\
\hline $\mathrm{N}$ of Bradley Nook Farm & 423320 & 347570 & Eumorphoceras pseudobilingue \\
\hline Duffield BH & 434280 & 342170 & $\begin{array}{l}\text { Eumorphoceras pseudobilingue, E. sp } \\
\text { (2 leaves) }\end{array}$ \\
\hline Upholland No $2 \mathrm{BH}$ & 350443 & 402870 & Eumorphoceras pseudobilingue \\
\hline \multicolumn{4}{|l|}{ Cravenoceras malhamense Marine Band (E1c1) } \\
\hline Moor Close Gill - near Malham & 393330 & 463940 & Cravenoceras malhamense \\
\hline $\begin{array}{l}\text { Swinhope Mine, from shale above Little } \\
\text { Limestone }\end{array}$ & 382600 & 546600 & Cravenoceras aff. malhamense \\
\hline Roosecote BH & 323040 & 468660 & Cravenoceras malhamense \\
\hline Burn Side & 368800 & 454370 & Cravenoceras malhamense \\
\hline Copped Hill Clough & 371140 & 457210 & Cravenoceras malhamense \\
\hline Hollow Gill Wood, south of Rathmell & 379900 & 458570 & Cravenoceras cf. malhamense \\
\hline Out Gang & 390760 & 461510 & Cravenoceras malhamense \\
\hline South of Stockdale Beck & 384550 & 463100 & Cravenoceras malhamense \\
\hline Cominco Borehole S9 40.5-45.4m depth & 383090 & 463300 & Cravenoceras malhamense \\
\hline Daw Haw Beck & 385100 & 466460 & Cravenoceras malhamense \\
\hline Crimple Beck & 425460 & 451780 & Cravenoceras malhamense \\
\hline Woodfold, Beacon Fell & 356790 & 442190 & Cravenoceras malhamense \\
\hline Duckey Leach BH From 294-324 ft depth & 373800 & 446800 & Cravenoceras sp. \\
\hline Railway cutting north of Wilpshire Tunnel & 368700 & 432900 & Cravenoceras malhamense \\
\hline Butler Clough & 372600 & 435400 & Cravenoceras malhamense \\
\hline Light Clough & 375200 & 437500 & Cravenoceras malhamense \\
\hline Little Mearley Clough & 378500 & 441100 & Cravenoceras malhamense \\
\hline Deep Clough & 380900 & 440300 & Cravenoceras malhamense \\
\hline 310 yards N50E from Firber House & 383400 & 443000 & Cravenoceras malhamense \\
\hline Weets Hollow & 385900 & 445100 & Cravenoceras malhamense \\
\hline Thornton Wood & 392000 & 448000 & Cravenoceras malhamense \\
\hline 300 yards S70W of Smearber & 393600 & 449200 & Cravenoceras malhamense \\
\hline $\begin{array}{l}\text { Carla Beck, } 300 \text { yards upstream from The } \\
\text { Grange }\end{array}$ & 397800 & 449400 & Cravenoceras malhamense \\
\hline Town Edge, south of Lothersdale & 395800 & 445800 & Cravenoceras malhamense \\
\hline & 403500 & 451600 & Cravenoceras cf. malhamense \\
\hline
\end{tabular}




\begin{tabular}{|c|c|c|c|}
\hline 570 yards N5W of Ramsgreave Hall & 367740 & 432010 & Cravenoceras malhamense \\
\hline Castleton $\mathrm{BH}$ & 414100 & 382930 & Cravenoceras malhamense \\
\hline LOCALITY & EASTING & $\begin{array}{l}\text { NORTHIN } \\
\text { G }\end{array}$ & AMMONOIDS \\
\hline \multicolumn{4}{|c|}{ Cravenoceras malhamense Marine Band (E1c1) Continued } \\
\hline Hope cement works BH, Salter Barn & 416780 & 382280 & Cravenoceras malhamense \\
\hline Abbey Mills BH 4 & 319490 & 377470 & Cravenoceras sp., Eumorphoceras sp. \\
\hline Horton, 450 yds $\mathrm{E}$ by $\mathrm{N}$ of The Rails & 391900 & 358550 & Cravenoceras \\
\hline Calow No $1 \mathrm{BH}$ & 440860 & 370410 & Cravenoceras malhamense \\
\hline Near Moorside & 404140 & 354570 & Cravenoceras sp. \\
\hline Duffield BH & 434280 & 342170 & $\begin{array}{l}\text { Cravenoceras malhamense, } \\
\text { Cravenoceras sp. }\end{array}$ \\
\hline Upholland No $2 \mathrm{BH}$ & 350443 & 402870 & Cravenoceras sp. \\
\hline \multicolumn{4}{|l|}{ Cravenoceras cowlingense Marine Band (E2a1) } \\
\hline Cockhill - Bewerley & 411200 & 464400 & Cravenoceras cowlingense \\
\hline Crook Dyke - Upper Nidderdale & 402570 & 476400 & Cravenoceras cowlingense \\
\hline Brigstsone Gill - Upper Swaledale - Yorks & 383900 & 501900 & Cravenoceras cowlingense \\
\hline Screes End, Tarnbrook & 360300 & 455400 & Cravenoceras cowlingense \\
\hline Great Ugly Clough, Quernmore & 351190 & 461120 & $\begin{array}{l}\text { Cravenoceras cowlingense, } E \text {. } \\
\text { grassingtonense }\end{array}$ \\
\hline Croft House Borehole, Newton-le-Wilows & 419820 & 488830 & Cravenoceras sp. \\
\hline Black Scar, Penhill & 404200 & 486900 & Cravenoceras cowlingense \\
\hline Gate Up Gill & 405700 & 467400 & Cravenoceras cowlingense \\
\hline Burn Gill, Nidderdale & 412800 & 468200 & Cravenoceras cowlingense \\
\hline Mirk Fell Gill & 391000 & 507000 & Cravenoceras cowlingense \\
\hline Oak Beck, Oakdale temporary exposure & 427450 & 454640 & Cravenoceras cowlingense \\
\hline Left bank, Grizedale Brook & 351170 & 447820 & Cravenoceras cowlingense \\
\hline North of Warley Wise Farm & 394400 & 443600 & Eumorphoceras bisulcatum \\
\hline $\begin{array}{l}50 \text { yards east of Owl Cotes, } 500 \text { yards ESE of } \\
\text { Mire Close }\end{array}$ & 396700 & 445000 & Eumorphoceras bisulcatum \\
\hline Cononley Beck & 398590 & 446910 & $\begin{array}{l}\text { Eumorphoceras grassingtonense, } \\
\text { Cravenoceras cowlingense }\end{array}$ \\
\hline Eller Beck & 400500 & 448800 & Eumorphoceras bisulcatum \\
\hline Edge & 402500 & 450000 & Eumorphoceras grassingtonense \\
\hline Bradley Gill & 400800 & 449300 & Eumorphoceras grassingtonense \\
\hline 350 yards NE of Kildwick Hall & 401400 & 446500 & Cravenoceras cowlingense \\
\hline $\begin{array}{l}\text { River Noe, } 20 \text { yds downstream of roadbridge } \\
\text { to Upper Booth }\end{array}$ & 410370 & 385120 & Cravenoceras cowlingense \\
\hline Alport Boring,near Alport,Derbyshire & 413612 & 391055 & $\begin{array}{l}\text { Cravenoceras cowlingense, } \\
\text { Eumorphoceras bisulcatum sl. }\end{array}$ \\
\hline R. Hamps near Ironpits & 406620 & 352040 & Cravenoceras cowlingense \\
\hline Lea Brook, near Cauldon & 407330 & 349690 & Eumorphoceras grassingtonense \\
\hline Moorside & 404380 & 354100 & Cravenoceras cowlingense \\
\hline Duffield BH & 434280 & 342170 & $\begin{array}{l}\text { Cravenoceras cowlingense, } \\
\text { Cravenoceras sp. }\end{array}$ \\
\hline Upholland No $2 \mathrm{BH}$ & 350443 & 402870 & Cravenoceras sp. \\
\hline \multicolumn{4}{|c|}{ Eumorphoceras ferrimontanum Marine Band (E2a2) } \\
\hline Tarnbrook Wyre, Abbeystead & 356800 & 454400 & Eumorphoceras ferrimontanum \\
\hline East of Ward's Stone & 359900 & 459100 & Eumorphoceras ferrimontanum \\
\hline Sapling Clough & 362600 & 456300 & Eumorphoceras ferrimontanum \\
\hline Upper Dove Valley & 406940 & 367250 & Eumorphoceras ferrimontanum \\
\hline Cogill Seave Bead, Lovely Seat & 388600 & 494800 & Cravenoceras aff. cowlingense \\
\hline Croft House Borehole, Newton-le-Wilows & 419820 & 488830 & Cravenoceras? \\
\hline Hookstone Beck & 431300 & 454190 & Eumorphoceras cf. ferrimontanum \\
\hline Stone Rings Beck & 430510 & 452750 & $\begin{array}{l}\text { Cravenoceras sp., Eumorphoceras } \\
\text { erinense }\end{array}$ \\
\hline Barnacre Lodge & 351580 & 446380 & $\begin{array}{l}\text { Cravenoceras sp., Eumorphoceras cf. } \\
\text { ferrimontanum, E. erinense }\end{array}$ \\
\hline Holbeck & 419800 & 447000 & $\begin{array}{l}\text { Eumorphoceras erinense, } E . \\
\text { ferrimontanum, Cravenoceras sp. }\end{array}$ \\
\hline River Washburn & 422900 & 447000 & $\begin{array}{l}\text { Eumorphoceras erinense, } E . \\
\text { ferrimontanum, Cravenoceras sp. nov, }\end{array}$ \\
\hline 775 yards $\mathrm{N}$ of Leathley Hall & 423700 & 447500 & $\begin{array}{l}\text { AMMONOIDEA Eumorphoceras } \\
\text { erinense, Cravenoceras sp. nov, } E . \\
\text { ferrimontanum }\end{array}$ \\
\hline R. Hamps near Crowtrees, Waterhouses & 407370 & 350250 & $\begin{array}{l}\text { Cravenoceras gairense, Eumorphoceras } \\
\text { bisulcatum \& Kazakhoceras scaliger }\end{array}$ \\
\hline Hulland & 424600 & 346220 & Eumorphoceras bisulcatum \\
\hline 0.75 mile SW of Wirksworth Church & 428020 & 353050 & Eumorphoceras bisulcatum \\
\hline
\end{tabular}




\begin{tabular}{|c|c|c|c|}
\hline LOCALITY & EASTING & $\begin{array}{l}\text { NORTHIN } \\
\text { G }\end{array}$ & AMMONOIDS \\
\hline \multicolumn{4}{|c|}{ Eumorphoceras ferrimontanum Marine Band (E2a2) Continued } \\
\hline Duffield $\mathrm{BH}$ & 434280 & 342170 & $\begin{array}{l}\text { Eumorphoceras bisulcatum, } \\
\text { Cravenoceras sp., Kazakhoceras } \\
\text { scaliger }\end{array}$ \\
\hline Upholland No 2 BH & 350443 & 402870 & $\begin{array}{l}\text { Eumorphoceras bisulcatum cf. erinense } \\
\text { \& ferrimontanum }\end{array}$ \\
\hline \multicolumn{4}{|c|}{ Cravenoceras gressinghamense Marine Band (E2a2a) } \\
\hline Gressingham Beck & 356440 & 469960 & Cravenoceras gressinghamense \\
\hline Hunt's Gill & 360560 & 467020 & Cravenoceras gressinghamense \\
\hline Badger Ford Beck & 369270 & 469808 & Cravenoceras gressinghamense \\
\hline Duffield BH & 434280 & 342170 & Eumorphoceras sp. \\
\hline \multicolumn{4}{|l|}{ Eumorphoceras yatesae Marine Band (E2a3) } \\
\hline $\begin{array}{l}\text { Mill Dam Beck - E of New Bridge - Weston - } \\
\text { Burley in Wharfdale }\end{array}$ & 417900 & 447900 & Eumorphoceras yatesae \\
\hline Croker Hill - $\mathrm{N}$ of Dawsons - Cheshire & 392710 & 367380 & Eumorphoceras yatesae \\
\hline Throstle Nest - Silsden - Yorkshire & 403800 & 446800 & Eumorphoceras yatesae \\
\hline Artle Beck & 355200 & 462470 & Eumorphoceras yatesae \\
\hline Coppice Beck, Harrogate & 430000 & 456200 & Eumorphoceras yatesae \\
\hline Sales Wheel, Samlesbury Hall & 367560 & 435850 & Eumorphoceras yatesae \\
\hline Duffield $\mathrm{BH}$ & 434280 & 342170 & Eumorphoceras yatesae, E. sp. \\
\hline Harewood BH SE34SW/37 & 432200 & 444100 & Cravenoceras \\
\hline \multicolumn{4}{|l|}{ Cravenoceratoides edalensis Marine Band (E2b1) } \\
\hline River Noe, right bank, $\mathrm{W}$ of Edale Mill & 412850 & 385120 & Cravenoceratoides edalense (type) \\
\hline $\begin{array}{l}\text { Bosley, stream W of Higher Minnend, E of } \\
\text { Hug Bridge }\end{array}$ & 393730 & 364590 & Cravenoceratoides edalense \\
\hline Throstle Nest - Silsden - Yorkshire & 403800 & 446800 & Cravenoceratoides aff. edalense \\
\hline Goodber Beck & 363920 & 460780 & $\begin{array}{l}\text { Cravenoceratoides edalensis, C. cf. } \\
\text { subplicatum }\end{array}$ \\
\hline Bowers Hall $\mathrm{BH}$ & 423490 & 364560 & Cravenoceratoides edalensis \\
\hline Knott Copy BH & 376980 & 464490 & Cravenoceratoides edalensis \\
\hline Coppice Beck, Harrogate & 430000 & 456200 & Cravenoceratoides edalensis \\
\hline Sales Wheel, Salesbury Hall & 367460 & 435850 & $\begin{array}{l}\text { Cravenoceratoides edalensis; } \\
\text { underlying C. subplicatum bed }\end{array}$ \\
\hline Alport Boring,near Alport,Derbyshire & 413612 & 391055 & Cravenoceratoides edalensis \\
\hline Ladywash crosscut & 422620 & 376930 & Cravenoceratoides edalensis \\
\hline R. Hamps near Winkhill & 406870 & 350410 & Cravenoceratoides edalensis \\
\hline SW of Shiningford & 424200 & 352360 & Cravenoceratoides edalensis \\
\hline Duffield BH & 434280 & 342170 & $\begin{array}{l}\text { Cravenoceratoides edalensis, } \\
\text { Cravenoceras sp. nov, C. sublicatum }\end{array}$ \\
\hline Harewood $\mathrm{BH}$ & 432200 & 444100 & Cravenoceratoides \\
\hline \multicolumn{4}{|l|}{ Cravenoceras nitidus Marine Band (E2b2) } \\
\hline River Ribble - Dinckley - Lancs. & 368640 & 436520 & Cravenoceratoides nitidum \\
\hline $\begin{array}{l}\text { Keasden (or Keasdon) Beck - } 0.25 \mathrm{ml} \text { above } \\
\text { Tunnerford Bridge - Clapham }\end{array}$ & 372440 & 465460 & Cravenoceratoides cf. nitidum \\
\hline Goodber Beck & 363920 & 460780 & Cravenoceratoides nitidum \\
\hline Greenholes Beck & 356480 & 463040 & Eumorphoceras leitrimense \\
\hline Branstone Beck & 367830 & 467860 & Eumorphoceras leitrimense \\
\hline Crag Hall BH, Ellel Grange & 348390 & 453450 & Cravenoceratoides cf. nitidus \\
\hline Wiggenstall & 409020 & 360780 & Cravenoceratoides nitidus \\
\hline Pow Gill, 130 yards $\mathrm{N}$ of bridge at Powbank & 325360 & 542300 & Anthrococeras glabrum \\
\hline Old Quarry, Wath, Nidderdale & 414600 & 468400 & Cravenoceratoides nitidus \\
\hline Cross Gill, Nidderdale & 404200 & 470800 & Cravenoceratoides nitidus \\
\hline NW slope of Great Whernside & 400200 & 476000 & Cravenoceratoides nitidus \\
\hline Stand Sike, Upper Nidderdale & 405100 & 477900 & Cravenoceratoides nitidus \\
\hline Thorny Crane Gill, Colsterdale & 411200 & 479600 & Cravenoceratoides nitidus \\
\hline Spruce Gill, Colsterdale & 413500 & 480300 & Cravenoceratoides nitidus \\
\hline Ulfers Gill, Colsterdale & 409300 & 482700 & Cravenoceratoides nitidus \\
\hline Knott Copy BH 3 & 376980 & 464490 & $\begin{array}{l}\text { Cravenoceratoides nitidus (lower), } \\
\text { Glaphyrites (middle), Gl. kettlesingense } \\
\text { (upper) }\end{array}$ \\
\hline Former brick pit at Stonefall & 433100 & 454800 & Cravenoceratoides nitidus \\
\hline $\begin{array}{l}\text { Crimple Beck between Pannal Bridge \& } \\
\text { Almsford Bridge }\end{array}$ & 430740 & 451660 & $\begin{array}{l}\text { Cravenoceratoides sp., Cravenoceras } \\
\text { sp., Eumorphoceras sp. }\end{array}$ \\
\hline
\end{tabular}




\begin{tabular}{|c|c|c|c|}
\hline Left bank, Grizedale Brook & 350740 & 447260 & Cravenoceratoides nitidus, C. holmesi \\
\hline Stubbing Beck & 396600 & 443800 & Cravenoceratoides sp., E. bisulcatum \\
\hline Harewood $\mathrm{BH}$ & 432200 & 444100 & Eumorphoceras \\
\hline Worthington $\mathrm{BH}$ & 440450 & 321040 & Cravenoceras subplicatum \\
\hline LOCALITY & EASTING & $\begin{array}{l}\text { NORTHIN } \\
\text { G }\end{array}$ & AMMONOIDS \\
\hline \multicolumn{4}{|l|}{ Cravenoceras nitidus Marine Band (E2b2) Continued } \\
\hline Hope cement works $\mathrm{BH}$, Salter Barn & 416780 & 382280 & $\begin{array}{l}\text { Cravenoceratoides cf., nitidus, } \\
\text { Cravenoceras cf. holmesi, } \\
\text { Eumorphoceras sp. }\end{array}$ \\
\hline Duffield BH & 434280 & 342170 & $\begin{array}{l}\text { Cravenoceratoides nitidus, } \\
\text { Eumorphoceras leitrimense, } \\
\text { Cravenoceras sp. }\end{array}$ \\
\hline Alport Boring,near Alport,Derbyshire & 413612 & 391055 & $\begin{array}{l}\text { Cravenoceratoides nitidus, } \\
\text { Eumorphoceras bisulcatum var. }\end{array}$ \\
\hline Upholland No 2 BH & 350443 & 402870 & $\begin{array}{l}\text { Eumorphoceras bisulcatum cf. } \\
\text { leitrimense }\end{array}$ \\
\hline \multicolumn{4}{|l|}{ Cravenoceras nititoides Marine Band (E2b3) } \\
\hline North of Endon & 392190 & 354140 & Cravenoceras sp. \\
\hline $\begin{array}{l}\text { E. bank of R. Crowden, } 10-20 \text { yds above } \\
\text { confluence with R. Noe }\end{array}$ & 410220 & 385260 & $\begin{array}{l}\text { Cravenoceras?, Eumorphoceras cf. } \\
\text { rostratum }\end{array}$ \\
\hline Alport Boring, near Alport, Derbyshire & 413612 & 391055 & $\begin{array}{l}\text { Cravenoceratoides nititoides, } \\
\text { Eumorphoceras cf. rostratum }\end{array}$ \\
\hline Hope cement works BH, Salter Barn & 416780 & 382280 & Cravenoceratoides nititoides \\
\hline River Terrig & 323380 & 356970 & Cravenoceratoides nititoides \\
\hline Combes Brook, S of Ballfields & 400770 & 352920 & Eumorphoceras rostratum \\
\hline River Ecclesbourne & 431370 & 345550 & $\begin{array}{l}\text { Cravenoceratoides nititoides, } \\
\text { Eumorphoceras rostratum }\end{array}$ \\
\hline Duffield BH & 434280 & 342170 & $\begin{array}{l}\text { Cravenoceratoides nititoides, } \\
\text { Eumorphoceras rostratum, } \\
\text { Cravenoceras sp. }\end{array}$ \\
\hline Harewood $\mathrm{BH}$ & 432200 & 444100 & Cravenoceras \\
\hline \multicolumn{4}{|l|}{ Nuculoceras stellarum Marine Band (E2c1) } \\
\hline Gill Beck - Cowling - N. Yorks & 395800 & 443600 & Cravenoceratoides stellarum \\
\hline Westfield Farm - Gill Beck - Cowling - Yorks. & 395800 & 443600 & Cravenoceratoides stellarum \\
\hline $\begin{array}{l}\text { Black Scars Beck, Cowling,SSW of Skipton } \\
\text { Station }\end{array}$ & 394100 & 443000 & Cravenoceratoides stellarum \\
\hline Cheddleton Paper Mills BH. & 397680 & 352470 & Nuculoceras stellarum \\
\hline $\begin{array}{l}\text { River Wharfe, right bank, } 200 \text { yards SE of } \\
\text { Netherby }\end{array}$ & 433300 & 446700 & Cravenoceratoides stellarum \\
\hline $\begin{array}{l}\text { Right bank of Gill Beck,10yds SSE of } \\
\text { Westfield 1230yds W 30degs N of Holy Trinity } \\
\text { Church, Cowling }\end{array}$ & 395800 & 443600 & Cravenoceratoides stellarum \\
\hline LOCALITY & EASTING & $\begin{array}{l}\text { NORTHIN } \\
\text { G }\end{array}$ & AMMONOIDS \\
\hline Carsington Reservoir BH CR10 & 424460 & 350200 & Nuculoceras stellarum \\
\hline Holehouse Lane & 392020 & 354830 & Nuculoceras stellarum \\
\hline Castleberg Scar, $30 \mathrm{ft}$ below Nesfield Sst & 409100 & 449600 & Nuculoceras stellarum \\
\hline Hole Brook & 360500 & 429400 & Cravenoceras stellarum, C. holmesi \\
\hline $\begin{array}{l}\text { E. bank of R. Crowden, } 10-20 \text { yds above } \\
\text { confluence with R. Noe }\end{array}$ & 410220 & 385260 & Nuculoceras stellarum \\
\hline Alport Boring, near Alport, Derbyshire & 413612 & 391055 & Nuculoceras stellarum \\
\hline Combes Brook & 401880 & 353330 & Nuculoceras stellarum \\
\hline River Ecclesbourne & 431370 & 345550 & Nuculoceras stellarum \\
\hline Duffield BH & 434280 & 342170 & Nuculoceras cf. stellarum \\
\hline Harewood BH & 432200 & 444100 & Nuculoceras stellarum \\
\hline \multicolumn{4}{|l|}{ Nuculoceras nuculum Marine Band (E2c2-4) } \\
\hline Tansley Bore - Derbyshire & 433126 & 359604 & Nuculoceras nuculum \\
\hline $\begin{array}{l}\text { Sutton - 240yds E by N of Crag \& SW of St } \\
\text { Thomas's Church - Sutton. }\end{array}$ & 400000 & 443500 & Nuculoceras nuculum \\
\hline R. Darwen, Samlesbury Bottoms,Blackburn & 361720 & 429360 & Nuculoceras nuculum \\
\hline Gill Beck - Cowling - N Yorks & 394730 & 443300 & Nuculoceras nuculum (upper 2 bands) \\
\hline $\begin{array}{l}\text { Bentend Farm - in stream 450yds SSW of } \\
\text { farm - near Dane Bridge - Staffs }\end{array}$ & 396420 & 363280 & Nuculoceras nuculum \\
\hline Owl Head Wood - Kearby - Yorks & 434500 & 446600 & $\begin{array}{l}\text { Nuculoceras nuculum, Cravenoceras } \\
\text { fragile (type) }\end{array}$ \\
\hline $\begin{array}{l}\text { Oakhill Clough - } 250 y d s \text { NNW of Stansfield } \\
\text { Hall Station - Todmorden }\end{array}$ & 393790 & 424870 & Nuculoceras nuculum (2 bands) \\
\hline Mam Tor $-0.75 \mathrm{ml} \mathrm{NW}$ of Castleton & 413150 & 383450 & Nuculoceras nuculum \\
\hline
\end{tabular}




\begin{tabular}{|c|c|c|c|}
\hline Tittesworth Reservoir - SW corner - Staffs. & 399220 & 358830 & Nuculoceras nuculum \\
\hline Sutton-on-Trent Well No.3 & 479900 & 364900 & Nuculoceras nuculum \\
\hline Shellag Point BH RTZ 1 & 245650 & 499650 & Nuculoceras nuculum \\
\hline Moor Hall, Bagnall & 394910 & 351180 & Nuculoceras nuculum \\
\hline Stoop Farm BH & 406500 & 368220 & Nuculoceras nuculum (upper band) \\
\hline Bowers Hall $\mathrm{BH}$ & 423490 & 364560 & Nuculoceras nuculum \\
\hline LOCALITY & EASTING & $\begin{array}{l}\text { NORTHIN } \\
\text { G }\end{array}$ & AMMONOIDS \\
\hline \multicolumn{4}{|c|}{ Nuculoceras nuculum Marine Band (E2c2-4) Continued } \\
\hline Field House & 412360 & 358390 & Nuculoceras nuculum \\
\hline Old Park Wood & 365220 & 434350 & Nuculoceras nuculum \\
\hline R. Ribble near Balderstone Hall & 361310 & 433300 & Nuculoceras nuculum (upper band) \\
\hline Shawhead Beck SSE of Shaw Gate (2 bands) & 392300 & 441500 & $\begin{array}{l}\text { Nuculoceras nuculum. E. bisulcatum, } \\
\text { Cravenoceratoides fragilis (middle), } \\
\text { Cravenoceras darwenense (middle), } \\
\text { Kazakhoceras hawkinsi (middle band) }\end{array}$ \\
\hline Black Scars & 394100 & 443000 & Nuculoceras nuculum (lower band) \\
\hline 340 yards E17N of Nesfield Church & 409600 & 449700 & $\begin{array}{l}\text { Nuculoceras nuculum, E. bisulcatum, } \\
\text { Cravenoceratoides fragilis? (lower band) }\end{array}$ \\
\hline 160 yards S $30 E$ of Gildersber & 407100 & 448800 & $\begin{array}{l}\text { Nuculoceras nuculum, E. bisulcatum, } \\
\text { Cravenoceratoides fragilis? (lower band) }\end{array}$ \\
\hline Crowden Brook & 410250 & 385400 & Nuculoceras nuculum \\
\hline $\begin{array}{l}\text { Grinds Brook, } 0.25 \text { miles N15W of Edale } \\
\text { church }\end{array}$ & 412210 & 386160 & Nuculoceras nuculum \\
\hline Alport Boring, near Alport, Derbyshire & 413612 & 391055 & $\begin{array}{l}\text { Nuculoceras nuculum, Eumorphoceras } \\
\text { bisulcatum ( } 3 \text { horizons) }\end{array}$ \\
\hline Dove Holes, railway cutting & 407610 & 379330 & $\begin{array}{l}\text { Nuculoceras nuculum, Eumorphoceras } \\
\text { bisulcatum }\end{array}$ \\
\hline $\begin{array}{l}\text { R. Derwent, } 660 \text { yds N84W of St Helen's } \\
\text { Church, Churchtown }\end{array}$ & 426070 & 363040 & Nuculoceras nuculum \\
\hline Cromford Station & 430340 & 357440 & $\begin{array}{l}\text { Nuculoceras nuculum, Eumorphoceras } \\
\text { bisulcatum }\end{array}$ \\
\hline Combes Brook & 400660 & 352920 & Nuculoceras nuculum (3 bands) \\
\hline Middle Cliff & 400020 & 354770 & $\begin{array}{l}\text { Nuculoceras nuculum, Eumorphoceras } \\
\text { bisulcatum (highest band) }\end{array}$ \\
\hline Ipstones Edge $\mathrm{BH}$ & 402580 & 351090 & Nuculoceras nuculum, (two bands) \\
\hline Biggin Brook & 425760 & 347770 & $\begin{array}{l}\text { Nuculoceras nuculum, Eumorphoceras } \\
\text { bisulcatum (lower band) }\end{array}$ \\
\hline Franker Brook & 430810 & 347290 & Nuculoceras nuculum (lower band) \\
\hline Duffield $\mathrm{BH}$ & 434280 & 342170 & Nuculoceras nuculum (3 bands) \\
\hline \multicolumn{4}{|l|}{ Isohomoceras subglobosum Marine Band (H1a1-3) } \\
\hline $\begin{array}{l}\text { Brunthwaite Beck - E of Brunthwaite } \& \text { S of } \\
\text { Parish Church - Silsden }\end{array}$ & 405200 & 446200 & Homoceras subglobosum \\
\hline $\begin{array}{l}\text { Rowley Wood, W of Low House \& S of Station } \\
\text { - Ben Rhydding }\end{array}$ & 414500 & 447100 & Homoceras cf subglobosum \\
\hline Ilkley, NE of Pomona/SW of Middleton, Ilkley & 412100 & 449000 & Homoceras cf subglobosum \\
\hline Stone Head Beck/Gill Beck - East of Colne & 394730 & 443300 & Homoceras subglobosum (3 bands) \\
\hline $\begin{array}{l}\text { Stream - between Ford of Meerbrook \& NW of } \\
\text { New Grange Farm - Staffs. }\end{array}$ & 399290 & 360330 & Homoceras subglobosum \\
\hline River Noe - below Edale Mill - Derbyshire & 413700 & 385450 & Homoceras subglobosum \\
\hline $\begin{array}{l}\text { River Darwen } 1500 \text { yards W of chapel at } \\
\text { Nab's Head }\end{array}$ & 360890 & 429270 & Homoceras subglobosum (3 bands) \\
\hline Alport Boring, Derbyshire & 413612 & 391055 & Homoceras subglobosum \\
\hline $\begin{array}{l}\text { Black Scars Beck - Cowling - } 5.25 \mathrm{mls} \text { SSW of } \\
\text { Skipton Station }\end{array}$ & 394100 & 443000 & Homoceras subglobosum \\
\hline $\begin{array}{l}\text { River Noe - left bank - 270yds S \& 77deg W of } \\
\text { Harrop Farm }\end{array}$ & 416660 & 385370 & Homoceras subglobosum (2 bands) \\
\hline $\begin{array}{l}\text { Tunnel Entrance - 1100yds N \& 12deg E of } \\
\text { Doveholes Station }\end{array}$ & 407700 & 479010 & Homoceras subglobosum \\
\hline Tittesworth Reservoir, 2mls North of Leek & 399210 & 358960 & Isohomoceras subglobosum \\
\hline $\begin{array}{l}\text { Stream section at Cocker Clough Wood, north } \\
\text { of Dolphinholme }\end{array}$ & 350780 & 455900 & Isohomoceras subglobosum \\
\hline Well Beck, near Summersgill & 363980 & 463600 & $\begin{array}{l}\text { Isohomoceras subglobosum (upper } \\
\text { band) }\end{array}$ \\
\hline Field House & 412360 & 358390 & Isohomoceras subglobosum \\
\hline Haddon Park Farm & 423020 & 367580 & Isohomoceras subglobosum \\
\hline R. Ribble near Balderstone Hall & 361330 & 433250 & $\begin{array}{l}\text { Isohomoceras subglobosum } \\
\text { (lower/middle band) }\end{array}$ \\
\hline Lumb Clough Beck & 400600 & 443600 & Isohomoceras subglobosum \\
\hline
\end{tabular}




\begin{tabular}{|c|c|c|c|}
\hline Swartha Wood & 405380 & 446560 & Isohomoceras subglobosum \\
\hline $\begin{array}{l}\text { Grinds Brook, } 0.25 \text { miles N15W of Edale } \\
\text { church }\end{array}$ & 412210 & 386160 & Isohomoceras subglobosum \\
\hline Crowden Brook, Upper Booth & 410270 & 385520 & Isohomoceras subglobosum \\
\hline R. Noe, 710 yds S15E of Clough Farm & 414750 & 385970 & Homoceras subglobosum (3 bands) \\
\hline Dove Holes, railway cutting & 407610 & 379330 & Homoceras subglobosum (lower band) \\
\hline LOCALITY & EASTING & $\begin{array}{l}\text { NORTHIN } \\
\text { G }\end{array}$ & AMMONOIDS \\
\hline \multicolumn{4}{|c|}{ Isohomoceras subglobosum Marine Band (H1a1-3) Continued } \\
\hline Quarry, Coed Llwybr-y-bi & 319280 & 375200 & $\begin{array}{l}\text { Isohomoceras subglobosum (lower } \\
\text { band) }\end{array}$ \\
\hline $\begin{array}{l}\text { Rushton, Dingle Brook, } 230 \text { yds SSE of } \\
\text { Harper's Farm }\end{array}$ & 392070 & 361750 & Homoceras subglobosum \\
\hline Horton, 160 yds NNE of Porter's Farm & 392600 & 359390 & Homoceras subglobosum \\
\hline Carsington Reservoir R11 BH & 424700 & 349860 & Isohomoceras subglobosum (3 bands) \\
\hline Ashcombe Park & 397710 & 351070 & $\begin{array}{l}\text { Isohomoceras subglobosum (1 band } \\
\text { seen) }\end{array}$ \\
\hline Boosemoor Brook & 437380 & 340530 & Homoceras subglobosum \\
\hline Mill Plantation & 437590 & 339550 & Homoceras subglobosum \\
\hline Duffield BH & 434280 & 342170 & Homoceras subglobosum (3 bands) \\
\hline \multicolumn{4}{|l|}{ Homoceras beyrichianum Marine Band (H1b1) } \\
\hline $\begin{array}{l}\text { Old Wives Gill, NE of Tivoli, 600yds WNW of } \\
\text { Myddleton Lodge, Ilkley }\end{array}$ & 410600 & 449500 & Homoceras beyrichianum \\
\hline Swartha Gill, Silsden & 405300 & 471000 & Homoceras beyrichianum \\
\hline $\begin{array}{l}\text { Ilkley, right bank Hebers Gill, } 1275 y d s \text { E \& } \\
\text { 3deg N of Netherwood House \& W of Station }\end{array}$ & 410120 & 447790 & Homoceras beyrichianum \\
\hline $\begin{array}{l}\text { Brunthwaite Beck, 220yds N \& 27deg E of } \\
\text { Brunthwaite, Silsden }\end{array}$ & 405300 & 446500 & Homoceras beyrichianum \\
\hline $\begin{array}{l}\text { Lumb Beck, 350yds SE of Throstle Nest, } \\
\text { Addingham }\end{array}$ & 408100 & 448600 & Homoceras beyrichianum \\
\hline Alport Boring, near Alport, Derbyshire & 413612 & 391055 & Homoceras beyrichianum \\
\hline $\begin{array}{l}\text { Lowgill, } 170 \mathrm{~m} \text { downstream of road bridge, } \\
\text { Crossdale Beck }\end{array}$ & 365620 & 465240 & $\begin{array}{l}\text { Homoceras beyrichianum, } \mathrm{H} \text {. cf. } \\
\text { diadema, Isohomoceras sp. }\end{array}$ \\
\hline Well Beck, near Summersgill & 365110 & 465460 & $\begin{array}{l}\text { Homoceras beyrichianum, } H . \text { cf. } \\
\text { diadema, Isohomoceras sp. }\end{array}$ \\
\hline Wiggenstall & 408750 & 360970 & Homoceras beyrichianum \\
\hline Stoop Farm BH & 406500 & 368220 & Homoceras beyrichianum \\
\hline Field House & 412360 & 358390 & Homoceras cf. beyrichianum \\
\hline Haddon Park Farm & 423020 & 367580 & Homoceras beyrichianum \\
\hline Gill Beck - Cowling - N Yorks. & 394730 & 443300 & Homoceras beyrichianum \\
\hline $\begin{array}{l}\text { Knott Copy } \mathrm{BH}-\text { nonsequence immediately } \\
\text { above marine band }\end{array}$ & 376980 & 464490 & Homoceras beyrichianum \\
\hline $\begin{array}{l}400 \text { yards S80E from Shaw Gate, Shawhead } \\
\text { Beck }\end{array}$ & 392500 & 441800 & Homoceras beyrichianum \\
\hline River Darwen & 361720 & 429360 & Homoceras beyrichianum \\
\hline $\begin{array}{l}\text { River Noe, left bank, 270yds S \& } 77 \text { deg W of } \\
\text { Harrop Farm }\end{array}$ & 416590 & 385540 & Homoceras beyrichianum \\
\hline Franker Brook & 430590 & 347610 & $\begin{array}{l}\text { Homoceras beyrichianum, } H \text {. cf. } \\
\text { subglobosum }\end{array}$ \\
\hline Ing Gill - Primrose Hill - Middleton - Ilkley & 411160 & 449710 & Homoceras aff. subglobosum \\
\hline \multicolumn{4}{|l|}{ Isohomoceras sp. nov. Marine Band (H1b2) } \\
\hline $\begin{array}{l}\text { Lowgill, } 170 \text { m downstream of road bridge, } \\
\text { Crossdale Beck }\end{array}$ & 365620 & 465240 & Isohomoceras sp. nov. \\
\hline Franker Brook & 430570 & 347740 & $\begin{array}{l}\text { Homoceras sp. aff. beyrichianum, } H . \text { sp. } \\
\text { of the subglobosum group }\end{array}$ \\
\hline \multicolumn{4}{|l|}{ Hudsonoceras proteum Marine Band (H2a1) } \\
\hline River Noe - Edale - Derbyshire & 409570 & 385540 & $\begin{array}{l}\text { Hudsonoceras proteum, Homoceras cf. } \\
\text { smithi ( } 3 \text { bands) }\end{array}$ \\
\hline Congleton Edge - Staffordshire & 387680 & 360570 & Hudsonoceras proteum \\
\hline Mam Tor - Castleton - Derbyshire & 412900 & 383400 & Hudsonoceras proteum \\
\hline Wiggenstall & 408990 & 360800 & Hudsonoceras proteum \\
\hline Blake Brook, Longnor & 406250 & 361190 & Hudsonoceras proteum \\
\hline Pendle Water, east of the inn at Roughlee & 384600 & 440400 & Hudsonoceras proteum \\
\hline R. Darwen, $\mathrm{N}$ of Samlesbury Bottoms & 361810 & 429090 & $\begin{array}{l}\text { Hudsonoceras proteus, Homoceras } \\
\text { smithi }\end{array}$ \\
\hline Crowden Brook, 640 yds N3E of Highfield & 410250 & 385630 & $\begin{array}{l}\text { Hudsonoceras proteus, Homoceras } \\
\text { smithi }\end{array}$ \\
\hline Grinds Brook, Grindsbrook Booth & 412220 & 386260 & $\begin{array}{l}\text { Hudsonoceras proteus (upper), } \\
\text { Homoceras smithi (lower) }\end{array}$ \\
\hline
\end{tabular}




\begin{tabular}{|l|r|r|l|}
\hline Harden Clough & 412240 & 384460 & \\
\hline Alport Boring,near Alport,Derbyshire & 413612 & 391055 & Hudsonoceras proteus \\
\hline 1010 yds S32E of Alport Castles Farm & 414010 & 390290 & $\begin{array}{l}\text { Hudsonoceras proteus, Homoceras } \\
\text { smithi }\end{array}$ \\
\hline Potbank Quarry, Newbold Astbury & 386910 & 359220 & Hudsonoceras proteus \\
\hline R. Derwent, 750 yds N89W of Stancliffe Hall & 426030 & 364010 & Hudsonoceras proteus \\
\hline Scow Brook & 424970 & 350930 & Hudsonoceras proteus \\
\hline
\end{tabular}

\begin{tabular}{|c|c|c|c|}
\hline LOCALITY & EASTING & $\begin{array}{l}\text { NORTHIN } \\
\text { G }\end{array}$ & AMMONOIDS \\
\hline \multicolumn{4}{|l|}{ Homoceras undulatum Marine Band (H2b1) } \\
\hline Ladywash Mine - Eyam - Derbyshire & 422500 & 376800 & Homoceras aff. undulatum \\
\hline $\begin{array}{l}\text { Brunthwaite Beck - 220yds N \& 27deg E of } \\
\text { Brunthwaite - Silsden }\end{array}$ & 405300 & 446500 & $\begin{array}{l}\text { Homoceras aff. undulatum, } H \text {. } \\
\text { beyrichianum }\end{array}$ \\
\hline $\begin{array}{l}\text { Lumb Clough Beck - 735yds S \& 13deg W of } \\
\text { Sutton Church - Yorks. }\end{array}$ & 400700 & 443500 & ? Homoceras undulatum \\
\hline Samlesbury - River Darwen & 361830 & 429160 & Homoceras undulatum \\
\hline Shell Brook - Greasley Hollow & 394700 & 366130 & Homoceras aff. undulatum \\
\hline $\begin{array}{l}\text { Roughlee - Right bank - immediately } \\
\text { downstream for Stepping Stones }\end{array}$ & 384600 & 440400 & Homoceras undulatum \\
\hline Eskew Beck, Bentham & 364890 & 468330 & Homoceras undulatum, $\mathrm{H}$. cf. smithi \\
\hline $\begin{array}{l}\text { Tittesworth Reservoir Water Treatment Plant- } \\
\mathrm{N} \text { of Leek }\end{array}$ & 399500 & 358500 & Homoceras undulatum \\
\hline $\begin{array}{l}\text { Right bank of stream, } 350 \text { yards SW of Lower } \\
\text { Jack Field }\end{array}$ & 399400 & 443400 & Homoceras cf. undulatum, $H$. cf. smithi \\
\hline Alport Boring, near Alport, Derbyshire & 413612 & 391055 & Homoceratoides cf. undulatum, \\
\hline 1010 yds S32E of Alport Castles Farm & 414010 & 390290 & Homoceras cf. undulatum \\
\hline Stream section & 322680 & 371130 & Homoceras undulatum \\
\hline Coed-y-cra & 327540 & 370590 & Homoceras undulatum \\
\hline $\begin{array}{l}\text { Rushton, Dingle Brook, } 370 \text { yds SW by W of } \\
\text { Fold Farm }\end{array}$ & 392750 & 361280 & Homoceras undulatum \\
\hline Franker Brook & 430550 & 347820 & Homoceras cf. undulatum \\
\hline \multicolumn{4}{|l|}{ Vallites eostriolatus Marine Band (H2c1) } \\
\hline $\begin{array}{l}\text { Right bank of River Darwen, 100yds NW of } \\
\text { bridge, Samlesbury Bottoms, Blackburn }\end{array}$ & 361830 & 429160 & Vallites eostriolatus \\
\hline Pendle Water, east of the inn at Roughlee & 384600 & 440400 & Homoceras eostriolatum \\
\hline $\begin{array}{l}\text { Hillside Section - 450yds E \& 13deg S of Knot } \\
\text { House - Eastburn - Sutton }\end{array}$ & 402100 & 444200 & $\begin{array}{l}\text { Homoceras aff. undulatum, } H . \mathrm{cf} . \\
\text { striolatum }\end{array}$ \\
\hline Alport Boring,near Alport, Derbyshire & 413612 & 391055 & Homoceras eostriolatum \\
\hline \multicolumn{4}{|c|}{ Homoceratoides prereticulatus Marine Band ( $\mathrm{H} 2 \mathrm{c} 2)$} \\
\hline $\begin{array}{l}\text { Roughlee - 10yds downstream from Stepping } \\
\text { Stones }\end{array}$ & 384600 & 440400 & Homoceratoides prereticulatus \\
\hline Mam Tor - Castleton - Derbyshire. & 410440 & 384300 & Homoceratoides prereticulatum \\
\hline Holden Beck, Silsden (Holotype) & 405940 & 445470 & Homoceratoides prereticulatum \\
\hline $\begin{array}{l}\text { River Darwen NW of Samlesbury Bridge,near } \\
\text { Blackburn Lancs }\end{array}$ & 361830 & 429160 & Homoceratoides cf. prereticulatum \\
\hline Blake Brook, Longnor & 406250 & 361190 & Homoceratoides prereticulatum \\
\hline $\begin{array}{l}\text { River Noe - at junction with Grains Clough - } \\
\text { Edale }\end{array}$ & 409530 & 385510 & Homoceratoides prereticulatum \\
\hline Harden Clough & 412240 & 384460 & $\begin{array}{l}\text { Homoceratoides aff. prereticulatum, } \\
\text { Homoceras sp. }\end{array}$ \\
\hline Alport Boring,near Alport,Derbyshire & 413612 & 391055 & Homoceratoides aff. prereticulatum \\
\hline Alport, ENE of Hayridge Farm & 414120 & 389690 & Homoceratoides prereticulatum \\
\hline R. Noe, 200 yds W-WNW of Fulwood Holmes & 416700 & 385000 & Homoceratoides prereticulatum \\
\hline Horton, 210 yds $\mathrm{N}$ by $\mathrm{E}$ of Bentend & 396600 & 363890 & Homoceratoides prereticulatus, H. sp. \\
\hline Biddulph, 420 yds $\mathrm{E}$ by $\mathrm{N}$ of Heath Hay & 390900 & 359310 & Homoceratoides prereticulatus \\
\hline Johannesburg No $6 \mathrm{BH}$ & 430370 & 359010 & Homoceratoides prereticulatus \\
\hline \multicolumn{4}{|l|}{ Hodsonites magistrorum Marine Band (R1a1) } \\
\hline Backstone Beck,SE of Ilkley Station Yorks & 412500 & 447200 & Homoceras [sp. nov. A] magistrorum \\
\hline Blake Brook, Longnor & 406250 & 361190 & Homoceras magistrorum \\
\hline $\begin{array}{l}\text { Right bank of River Darwen 100yds NW of } \\
\text { Bridge,Samlesbury Bottoms, near Blackburn }\end{array}$ & 361830 & 429160 & Homoceras magistrorum \\
\hline Alport, ENE of Hayridge Farm & 414120 & 389690 & Homoceras sp. \\
\hline Maplebeck Well & 470520 & 360090 & Homoceras cf. magistrorum \\
\hline \multicolumn{4}{|l|}{ Reticuloceras circumplicatile Marine Band (R1a2) } \\
\hline Pendle Water - Rough Lee - Nelson & 384500 & 440300 & Reticuloceras circumplicatile \\
\hline Blake Brook, Longnor & 406250 & 361190 & Reticuloceras circumplicatile \\
\hline Right bank of River Darwen 100yds NW of & 361830 & 429160 & Reticuloceras circumplicatile \\
\hline
\end{tabular}




\begin{tabular}{|c|c|c|c|}
\hline \multicolumn{4}{|l|}{ Bridge,Samlesbury Bottoms, near Blackburn } \\
\hline Mousegill Beck, Stainmore & 383520 & 512490 & Vallites henkei \\
\hline Franker Brook & 430560 & 347880 & $\begin{array}{l}\text { Reticuloceras circumplicatile, Vallites. } \\
\text { henkei, Homoceratoides sp. }\end{array}$ \\
\hline Ferriby Brook & 437870 & 339660 & $\begin{array}{l}\text { Reticuloceras circumplicatile, Vallites } \\
\text { henkei }\end{array}$ \\
\hline \multicolumn{4}{|l|}{ Reticuloceras subreticulatum Marine Band (R1a3) } \\
\hline Grinds Brook, 25 yds E of Grindslow House & 412140 & 386350 & $\begin{array}{l}\text { Homoceratoides sp., Reticuloceras cf. } \\
\text { pulchellum, R. cf. subreticulatum }\end{array}$ \\
\hline LOCALITY & EASTING & $\begin{array}{l}\text { NORTHIN } \\
\text { G }\end{array}$ & AMMONOIDS \\
\hline \multicolumn{4}{|c|}{ Reticuloceras subreticulatum Marine Band (R1a3) Continued } \\
\hline Franker Brook & 430590 & 347960 & Reticuloceras subreticulatum \\
\hline Ferriby Brook & 437970 & 339720 & Reticuloceras cf. subreticulatum \\
\hline \multicolumn{4}{|l|}{ Reticuloceras todmordenense Marine Band (R1a4) } \\
\hline Lumbutts Clough, Woodhouse, Todmorden & 395030 & 424220 & Reticuloceras todmordenense \\
\hline Roughlee - Pendle & 384600 & 440400 & Reticuloceras todmordenense \\
\hline Brund BHs, Manifold valley & 408920 & 361530 & Reticuloceras cf. todmordenense \\
\hline Knott Copy BH & 376980 & 464490 & $\begin{array}{l}\text { Reticuloceras todmordenense, } R . \\
\text { paucicrenulatum, } R \text {. aff. adpressum }\end{array}$ \\
\hline Farnham $\mathrm{BH}$ & 434690 & 459960 & Reticuloceras paucicrenulatum \\
\hline Grinds Brook, 25 yds E of Grindslow House & 412140 & 386350 & $\begin{array}{l}\text { Homoceras sp., Reticuloceras sp., } R \text {. } \\
\text { ?todmordense }\end{array}$ \\
\hline \multicolumn{4}{|l|}{ Reticuloceras dubium Marine Band (R1a5) } \\
\hline $\begin{array}{l}\text { Holden Beck - } \mathrm{N} \text { of Holden Bridge - S of } \\
\text { Silsden Parish Church }\end{array}$ & 405900 & 445500 & Reticuloceras cf. dubium \\
\hline Knott Copy BH & 376980 & 464490 & Reticuloceras dubium \\
\hline $\begin{array}{l}\text { 533yds SSW of Haggs Rd Farm, Spofforth } \\
\text { Haggs - North Yorkshire }\end{array}$ & 433740 & 450700 & Reticuloceras dubium \\
\hline \multicolumn{4}{|c|}{ Reticuloceras dubium Marine Band (R1a5) Continued } \\
\hline Greenway Hall Golf Course & 391860 & 351270 & Reticuloceras cf. dubium, R. sp. \\
\hline Bentham Station BH & 366590 & 468930 & Reticuloceras dubium \\
\hline Blackwood End Farm, Quernmore & 351270 & 457810 & Reticuloceras dubium \\
\hline Samlesbury - River Darwen & 361830 & 429160 & Reticuloceras dubium \\
\hline \multicolumn{4}{|l|}{ Reticuloceras eoreticulatum Marine Band (R1b1) } \\
\hline Mam Tor - Castleton - Derbyshire & 412990 & 383460 & Reticuloceras eoreticulatum \\
\hline Black Bank Syke & 376370 & 465270 & Reticuloceras sp. \\
\hline $\begin{array}{l}\text { Roughlee (type specimen) large scar on right } \\
\text { bank } 65 \text { yards upstream of stepping stones }\end{array}$ & 384300 & 440200 & Reticuloceras eoreticulatum \\
\hline \multicolumn{4}{|l|}{ Reticuloceras nodosum Marine Band (R1b2) } \\
\hline Swint Clough - Alport Valley & 413470 & 391060 & $\begin{array}{l}\text { Reticuloceras nodosum, Homoceras } \\
\text { spiraloides, } H \text {. striolatum }\end{array}$ \\
\hline Spofforth Haggs - North Yorkshire & 433740 & 450700 & Reticuloceras nodosum group \\
\hline $\begin{array}{l}\text { Porters Farm - 420yds East }+3 \text { deg South of } \\
\text { Porters Farm - Horton }\end{array}$ & 392930 & 359140 & Reticuloceras cf. nodosum \\
\hline Brund BHs, Manifold valley & 408920 & 361530 & Reticuloceras aff. nodosum \\
\hline Mam Tor - Castleton - Derbyshire & 412990 & 383460 & Reticuloceras cf. nodosum \\
\hline \multicolumn{4}{|l|}{ Reticuloceras stubblefieldi Marine Band (R1b3) } \\
\hline River Noe - Edale - Derbyshire & 417640 & 383170 & Reticuloceras stubblefieldi \\
\hline 1000m ENE of Bull Bank & 362880 & 472060 & Reticuloceras cf. stubblefieldi \\
\hline Brund BHs, Manifold valley & 408920 & 361530 & Reticuloceras cf. stubblefieldi \\
\hline Acton Burn, north of Derwent Reservoir & 398300 & 552880 & Reticuloceras cf. stubblefieldi (juv) \\
\hline Crag Gill, near White House & 402680 & 523620 & Reticuloceras stubblefieldi \\
\hline Black Bank Syke & 376370 & 465270 & Reticuloceras stubblefieldi \\
\hline Swint Clough - Alport Valley - Derbyshire & 413470 & 391060 & $\begin{array}{l}\text { Reticuloceras cf. stubblefieldi, } \\
\text { Hudsonoceras ornatum, R. aff. Moorei, } \\
\text { R. cf. regularum }\end{array}$ \\
\hline Franker Brook & 430600 & 348050 & $\begin{array}{l}\text { Reticuloceras stubblefieldi , } H . \text { cf. } \\
\text { striolatum }\end{array}$ \\
\hline $\begin{array}{l}\text { Upper part of shale quarry, Earle's cement } \\
\text { works, southern slope of the Folly, Hope }\end{array}$ & 417000 & 382600 & $\begin{array}{l}\text { Reticuloceras stubblefieldi (type } \\
\text { specimen) }\end{array}$ \\
\hline \multicolumn{4}{|l|}{ Reticuloceras reticulatum Marine Band (R1c1-3) } \\
\hline Eccup - 4.5mls NNW of Leeds - Yorkshire & 428000 & 442000 & Reticuloceras reticulatum \\
\hline Stanbury, adit spoil, Sladen Bridge, Stanbury & 401800 & 437200 & Reticuloceras reticulatum (type form) \\
\hline Woodfold Park Nab's Head & 363720 & 428840 & Reticuloceras cf. reticulatum \\
\hline $\begin{array}{l}\text { Clough - W of Ewood Hall - 1100yds NW of } \\
\text { Todmorden Station }\end{array}$ & 392730 & 424720 & Reticuloceras cf. reticulatum \\
\hline $\begin{array}{l}\text { Black Scout, Crimsworth Dean, Hebden } \\
\text { Bridge }\end{array}$ & 3988170 & 429820 & Reticuloceras reticulatum \\
\hline
\end{tabular}




\begin{tabular}{|c|c|c|c|}
\hline $\begin{array}{l}\text { Shewboard (or Shrewbroad) Clough, } \\
\text { Todmorden }\end{array}$ & 393590 & 423700 & Reticuloceras reticulatum \\
\hline Shell Brook - Mareknowles - Staffordshire & 394770 & 365640 & Reticuloceras reticulatum \\
\hline Quarmby Clough Mills BH SE11NW/8 & 411453 & 4167370 & Reticuloceras reticulatum \\
\hline Greenway Hall Golf Course & 391860 & 351270 & Reticuloceras reticulatum \\
\hline Grange Brickworks, Killinghall & 428650 & 457700 & $\begin{array}{l}\text { Reticuloceras reticulatum, Vallites sp., } \\
\text { V. striolatus }\end{array}$ \\
\hline Stockeld BH SE34NE/16 & 438030 & 449450 & $\begin{array}{l}\text { Reticuloceras reticulatum, Vallites. } \\
\text { striolatus }\end{array}$ \\
\hline Sabden Brook & 374600 & 434500 & Reticuloceras reticulatum, $R$. davisi \\
\hline LOCALITY & EASTING & $\begin{array}{l}\text { NORTHIN } \\
\text { G }\end{array}$ & AMMONOIDS \\
\hline \multicolumn{4}{|c|}{ Reticuloceras reticulatum Marine Band (R1c1-3) Continued } \\
\hline Westfield Mills BH,Yeadon SE24SW/1 & 420450 & 440940 & Reticuloceras cf. reticulatum reticulatum \\
\hline $\begin{array}{l}\text { Co-operative Laundry SE04SE } 6 \text { BH 49.99- } \\
51.51 \mathrm{~m} \text { depth }\end{array}$ & 405800 & 441200 & Reticuloceras cf. reticulatum reticulatum \\
\hline Samlesbury - River Darwen & 361830 & 429160 & Reticuloceras reticulatum \\
\hline Samlesbury - River Darwen & 362410 & 428640 & $\begin{array}{l}\text { Reticuloceras reticulatum, R. davisi, } \\
\text { Homoceras striolatum }\end{array}$ \\
\hline $\begin{array}{l}\text { Samlesbury - River Darwen } 300 \text { yards W of } \\
\text { Beardwood Hall }\end{array}$ & 365960 & 428840 & $\begin{array}{l}\text { Reticuloceras cf. reticulatum, } R \text {. cf. } \\
\text { regularum, Homoceras striolatum }\end{array}$ \\
\hline Stream below Wimberry Stone & 401500 & 402500 & Reticuloceras reticulatum type \\
\hline River Noe & 409250 & 385760 & Reticuloceras reticulatum \\
\hline Swint Clough - Alport Valley - Derbyshire & 413470 & 391060 & Reticuloceras reticulatum ss. \\
\hline Eyam View & 421420 & 377190 & Reticuloceras reticulatum ss. \\
\hline South Leverton No $1 \mathrm{BH}$ & 479330 & 380400 & Reticuloceras cf. reticulatum \\
\hline Biddulph, 265 yds E of Heath Hay & 390770 & 359280 & Homoceratoides prereticulatus \\
\hline Franker Brook & 430510 & 348120 & Reticuloceras cf. reticulatum \\
\hline \multicolumn{4}{|l|}{ Reticuloceras coreticulatum Marine Band (R1c4) } \\
\hline $\begin{array}{l}\text { Pendle Water, right bank, Rough Lee, Forest } \\
\text { of Pendle }\end{array}$ & 384000 & 437000 & Reticuloceras coreticulatum \\
\hline $\begin{array}{l}\text { Sabden Brook - 1250' N of confluence with } \\
\text { River Calder }\end{array}$ & 374600 & 434400 & Reticuloceras aff. coreticulatum \\
\hline $\begin{array}{l}\text { Ponden Clough - 550yds upstream from } \\
\text { Ponden Reservoir - Stanbury }\end{array}$ & 398700 & 436700 & $\begin{array}{l}\text { Reticuloceras coreticulatum, } \mathrm{R} . \\
\text { reticulatum }\end{array}$ \\
\hline Heysham Power Station BH SD45NW/229 & 340450 & 459890 & $\begin{array}{l}\text { Reticuloceras coreticulatum, } \\
\text { Homoceratoides divaricatus, } R \text {. } \\
\text { reticulatum }\end{array}$ \\
\hline $\begin{array}{l}\text { Co-operative Laundry BH SE04SE/6 49.99- } \\
51.51 \mathrm{~m} \text { depth }\end{array}$ & 405800 & 441200 & $\begin{array}{l}\text { Reticuloceras coreticulatum, } R \text {. } \\
\text { reticulatum, Hudsonoceras ornatum, }\end{array}$ \\
\hline Bradup BH SE04SE/774 97.85-99.85m & 409140 & 444170 & Reticuloceras coreticulatum \\
\hline Westfield Mills BH - Yeadon SE24SW/1 & 420450 & 440940 & Reticuloceras reticulatum late form \\
\hline Clough Hole & 401800 & 436800 & Reticuloceras reticulatum \\
\hline $\begin{array}{l}\text { Wike Whin } 1.25 \text { miles WSW of Bardsey } \\
\text { church }\end{array}$ & 434500 & 442200 & $\begin{array}{l}\text { Reticuloceras coreticulatum, } R . \\
\text { reticulatum }\end{array}$ \\
\hline Callow $\mathrm{BH}$ & 426650 & 352820 & Reticuloceras spp., R. coreticulatum \\
\hline \multicolumn{4}{|l|}{ Bilinguites gracilis Marine Band (R2a1) } \\
\hline Bankfield Mills BH, Mold Green SE11NE/11 & 414660 & 416270 & Reticuloceras gracile \\
\hline Foster Clough - Mytholmroyd Station & 401880 & 427210 & Reticuloceras gracile \\
\hline $\begin{array}{l}\text { Mount Road,Pule Hill, } 400 y d s \text { E by } \mathrm{N} \text { of } \\
\text { Gilberts Farm, Marsden }\end{array}$ & 403160 & 410120 & Reticuloceras gracile \\
\hline Birchover Borehole, Buxton SK26SW/16 & 424130 & 362330 & Bilinguites gracile \\
\hline Yeadon Waterworks BH - SE24SW/14 & 422410 & 442470 & Reticuloceras gracile late mut. alpha \\
\hline $\begin{array}{l}\text { Holme Woods Dike - 130yds S of Holme } \\
\text { Woods - 1mile S of Holme }\end{array}$ & 410460 & 404450 & Reticuloceras gracile \\
\hline $\begin{array}{l}\text { Grinding Stone Hole - Rag Clough - W of } \\
\text { Church - Oxenhope }\end{array}$ & 401400 & 433800 & Reticuloceras gracile \\
\hline $\begin{array}{l}\text { Alum Crag - NNE of Alum Scar - 1.1/8ml SE of } \\
\text { Chapel - Nabs Head }\end{array}$ & 363680 & 428050 & Reticuloceras gracile late mut. \\
\hline Butts Clough - 100yds NE of Rishworth Mills & 403750 & 418020 & Reticuloceras gracile, R.reticulatum \\
\hline Rake Dike - Holme - Holmfirth - Yorkshire & 409980 & 405210 & Reticuloceras gracile \\
\hline Sun Hill Clough - Oxenhope & 400600 & 434000 & Reticuloceras gracile \\
\hline $\begin{array}{l}\text { Long Ridge - 630yds SSE of North Grain with } \\
\text { Howels Head Clough }\end{array}$ & 404940 & 403940 & Reticuloceras reticulatum mut. gracile \\
\hline Star Wood, 1ml NE of Oakamoor & 406120 & 346080 & Reticuloceras gracile (2 bands) \\
\hline $\begin{array}{l}\text { Bank of Salter's Brook,550 SSW of Salter's } \\
\text { Brook Bridge, Woodhead }\end{array}$ & 413510 & 399660 & Reticuloceras reticulatum mut. alpha \\
\hline Greenway Hall Golf Course & 391860 & 351270 & Bilinguites gracilis \\
\hline Heysham Power Station BH SD45NW/229 & 340450 & 459890 & Bilinguites gracilis \\
\hline
\end{tabular}




\begin{tabular}{|c|c|c|c|}
\hline Seat Hall BH SD66NE/2 & 366030 & 469820 & Bilinguites gracilis \\
\hline Tittesworth Farm & 400040 & 358740 & $\begin{array}{l}\text { Bilinguites gracilis (Lower and both } \\
\text { middle bands of Marine Band) }\end{array}$ \\
\hline River Churnet north of Swainsmoor & 402410 & 361900 & $\begin{array}{l}\text { Bilinguites gracilis (Both middle bands } \\
\text { of Marine Band) }\end{array}$ \\
\hline Boreholes near Brund & 409630 & 361780 & $\begin{array}{l}\text { Bilinguites gracilis ( } 3 \text { bands of Marine } \\
\text { Band: Reticuloceras sp. nov, in Upper } \\
\text { and lower Middle band) }\end{array}$ \\
\hline NE of Pilsley & 423260 & 371750 & Bilinguites gracilis late form \\
\hline Newton Bank BH & 395820 & 395060 & Bilinguites gracilis late form \\
\hline Park Clough, Hey Green, Marsden & 402990 & 412460 & Bilinguites gracilis \\
\hline Farnham BH SE35NE 27 & 434690 & 459960 & Bilinguites gracilis \\
\hline LOCALITY & EASTING & $\begin{array}{l}\text { NORTHIN } \\
\text { G }\end{array}$ & AMMONOIDS \\
\hline \multicolumn{4}{|l|}{ Bilinguites gracilis Marine Band (R2a1) Continued } \\
\hline Sabden Brook & 374600 & 434300 & Reticuloceras gracile late form \\
\hline Rams Clough & 391000 & 432100 & Reticuloceras gracile late form \\
\hline $\begin{array}{l}\text { Bradup BH SE04SE/774 23.05-24.49m (upper } \\
\text { band); } 26.15-28.48 m \text { (lower band) }\end{array}$ & 409140 & 444170 & $\begin{array}{l}\text { Reticuloceras gracile type \& late form } \\
\text { (lower band) and early (upper band) }\end{array}$ \\
\hline Aire Valley BH 29 SE04SE/17 35.5-37.0m & 408990 & 440570 & Reticuloceras gracile early form \\
\hline Westfield Mills BH - Yeadon SE24SW/1 & 420450 & 440940 & Reticuloceras gracile late mut. alpha \\
\hline Kirk Lane Dye Works BH SE24SW/4a & 420350 & 441020 & Reticuloceras gracile late mut. alpha \\
\hline Horsforth Water Works BH SE24SW/7a & 423370 & 441160 & Reticuloceras gracile late mut. alpha \\
\hline $\begin{array}{l}\text { Junction of Bent \& Middle Moor cloughs } 800 \\
\text { yards N of High Greave }\end{array}$ & 399200 & 433600 & $\begin{array}{l}\text { Reticuloceras reticulatum early mut. } \\
\text { alpha }\end{array}$ \\
\hline Paul Clough 640 yards SE of Aberdeen & 403100 & 433900 & $\begin{array}{l}\text { Reticuloceras reticulatum late mut. } \\
\text { alpha \& mut. alpha }\end{array}$ \\
\hline Sough Hole 330 yards NW of Two Laws & 397400 & 438300 & Reticuloceras reticulatum mut. alpha \\
\hline $\begin{array}{l}\text { Victoria Hospital, Keighley } 1040 \text { yards SW of } \\
\text { Cliffe Castle }\end{array}$ & 405300 & 441500 & $\begin{array}{l}\text { Reticuloceras reticulatum late mut. } \\
\text { alpha }\end{array}$ \\
\hline $\begin{array}{l}\text { Brickpit (Park Wood Brick co) 530yds S 6degs } \\
\text { S of station, Keighley }\end{array}$ & 406600 & 440700 & $\begin{array}{l}\text { Reticuloceras reticulatum cf. late mut } \\
\text { alpha, } R \text {. reticulatum ( } 2 \text { bands) }\end{array}$ \\
\hline Snail Green BH & 411800 & 442500 & Reticuloceras gracile mut. alpha \\
\hline Banksfield Dye Works BH & 420700 & 441500 & Reticuloceras gracile aff. mut alpha \\
\hline Corringham No $3 \mathrm{BH}$ & 489050 & 393520 & Bilinguites gracilis \\
\hline Trumfleet No 1 BH SE51SE/1 & 460520 & 412640 & Bilinguites gracilis \\
\hline Moss Oil BH SE51SE/19 & 459980 & 413900 & $\begin{array}{l}\text { Bilinguites gracilis, B. gracilis (early } \\
\text { form) }\end{array}$ \\
\hline $\begin{array}{l}\text { W bank of Long Clough, c } 400 y d s \text { W of bridge } \\
\text { on Glossop-Hayfield road }\end{array}$ & 403020 & 390730 & Reticuloceras gracile \\
\hline The Heys & 404390 & 385540 & Reticuloceras gracile \\
\hline Whitehall Works BH & 403550 & 382020 & Reticuloceras gracile \\
\hline Forge Works No. $3 \mathrm{BH}$ & 404170 & 382190 & Reticuloceras gracile \\
\hline Clough, 0.25 miles NNE of Ridge Hall & 405950 & 379250 & Reticuloceras cf. gracile \\
\hline 300 yds NW of Cowlow Farm & 406620 & 378780 & Reticuloceras gracile [evolute form] \\
\hline Stream near Dunge Farm & 398900 & 377690 & Reticuloceras gracile \\
\hline S bank of stream 1 mile NW of Hallfield & 423300 & 392890 & Reticuloceras gracile \\
\hline E bank of stream, W of Bole Edge Plantation & 422590 & 392000 & Reticuloceras cf. gracile and late form \\
\hline N side of Raddlepit Rushes in Strines Dike & 421040 & 389740 & Reticuloceras gracile late form \\
\hline Moscar Moor & 422230 & 387360 & Reticuloceras gracile late form \\
\hline $\begin{array}{l}210 \text { yds NNE of Mitchell Field, E of } \\
\text { Hathersage }\end{array}$ & 424870 & 381920 & Reticuloceras gracile \\
\hline Leeswood Old Hall BH & 326360 & 361800 & Bilinguites gracilis \\
\hline Coed-y-felin stream section & 322370 & 371500 & Bilinguites gracilis \\
\hline $\begin{array}{l}\text { North Rode, } N \text { bank of R. Dane, } 760 \text { yds S by } \\
\text { E of Ladderstile }\end{array}$ & 390240 & 365310 & $\begin{array}{l}\text { Reticuloceras gracile early and late } \\
\text { forms }\end{array}$ \\
\hline $\begin{array}{l}\text { Rushton, Dingle Brook, } 350 \text { yds SE by E of } \\
\text { Harper's Farm }\end{array}$ & 392250 & 361760 & $\begin{array}{l}\text { Reticuloceras gracile early and late } \\
\text { forms }\end{array}$ \\
\hline Biddulph, 250 yds E by S of Heath Hay & 390740 & 359220 & Reticuloceras gracile early form \\
\hline Abbey Mills $\mathrm{BH} 4$ & 319490 & 377470 & Reticuloceras gracile late form \\
\hline Ashover, 1033 yds S20E of Raven House & 435570 & 360270 & Reticuloceras gracile late form \\
\hline Tansley BH - Derbyshire & 433126 & 359604 & Reticuloceras gracile, and early form \\
\hline Bothamsall No $1 \mathrm{BH}$ & 465860 & 373675 & Reticuloceras gracile \\
\hline Kelham Hills No $51 \mathrm{BH}$ & 476480 & 357500 & Reticuloceras gracile \\
\hline Kelham Hills No $1 \mathrm{BH}$ & 475940 & 357620 & Reticuloceras gracile late form \\
\hline Eakring No $1 \mathrm{BH}$ & 467600 & 361330 & Reticuloceras gracile late form \\
\hline Eakring No $3 \mathrm{BH}$ & 467710 & 361450 & Reticuloceras gracile \\
\hline Felthouse Wood & 397900 & 350200 & Reticuloceras gracile \\
\hline Rotherwood $\mathrm{BH}$ & 434580 & 315590 & Bilinguites cf. gracilis \\
\hline
\end{tabular}




\begin{tabular}{|c|c|c|c|}
\hline Callow BH & 426650 & 352820 & Reticuloceras gracilis \\
\hline Shottlegate & 431370 & 347410 & Reticuloceras gracilis \\
\hline $\begin{array}{l}\text { Load Clough, } 700 y d s \text { S by E of Luddenden } \\
\text { Parish Church }\end{array}$ & 404400 & 425590 & Reticuloceras reticulatum \\
\hline Clark Bridge Mills - Halifax & 409846 & 425166 & Reticuloceras reticulatum \\
\hline $\begin{array}{l}\text { Butterley Clough - W bank of Gorge at top of } \\
\text { Clough - Swellands Reservoir - Marsden }\end{array}$ & 404080 & 409010 & Reticuloceras reticulatum mut alpha \\
\hline Worthington $\mathrm{BH}$ SK24SW/204 & 440450 & 321040 & Bilinguites gracilis \\
\hline Asfordby Hydro BH SK72SW/71 & 472520 & 320610 & Bilinguites sp. \\
\hline \multicolumn{4}{|l|}{ Bilinguites bilinguis Marine Band (R2b1-3) } \\
\hline $\begin{array}{l}\text { Dry Clough,Warm Withens, Rishworth Moor,W } \\
\text { of Rishworth }\end{array}$ & 399030 & 417750 & $\begin{array}{l}\text { Reticuloceras reticulatum late mut } \\
\text { alpha, Bilinguites bilinguis (R2b1-2) }\end{array}$ \\
\hline Netherend's Beck - right bank - Sowerby & 404110 & 422270 & Reticuloceras bilingue (R2b1-2) \\
\hline LOCALITY & EASTING & $\begin{array}{l}\text { NORTHIN } \\
\text { G }\end{array}$ & AMMONOIDS \\
\hline \multicolumn{4}{|c|}{ Bilinguites bilinguis Marine Band (R2b1-3) Continued } \\
\hline Phoenix Mills BH Huddersfield & 414940 & 417500 & $\begin{array}{l}\text { Reticuloceras reticulatum mut. bilingue } \\
\text { (R2b1-2) }\end{array}$ \\
\hline $\begin{array}{l}\text { W bank of Long Clough,c 400yds W of bridge } \\
\text { on Glossop-Hayfield road }\end{array}$ & 403020 & 390730 & $\begin{array}{l}\text { Reticuloceras bilingue early form } \\
\text { (R2b1-2) }\end{array}$ \\
\hline $\begin{array}{l}\text { Section in cut of bank 150yds N 31degs of } \\
\text { High Cote, Riddlesden }\end{array}$ & 406800 & 443000 & $\begin{array}{l}\text { Reticuloceras reticulatum mut. bilingue } \\
\text { (R2b1-2) }\end{array}$ \\
\hline High Marcroft Fold - Near Rochdale & 384100 & 414800 & Reticuloceras bilingue (R2b1-2) \\
\hline March Hill - $\mathrm{N}$ of Dobcross & 400800 & 413270 & Bilinguites bilinguis (R2b1-2) \\
\hline $\begin{array}{l}\text { Brickpit (Park Wood Brick co) 530yds S 6degs } \\
\text { S of station, Keighley }\end{array}$ & 406600 & 440700 & $\begin{array}{l}\text { Reticuloceras reticulatum mut. bilingue } \\
\text { (R2b1-2) }\end{array}$ \\
\hline Rake Dyke @ 12000' OD 1mile SW of Holme & 409670 & 404980 & Reticuloceras bilingue (R2b1-2) \\
\hline Kitchen Clough - Slaithwaite & 408150 & 413470 & Reticuloceras bilingue (R2b1-2) \\
\hline Bank of R Dane W of Swythanley Hall Church & 396320 & 364520 & Reticuloceras bilingue (R2b1-2) \\
\hline Bankfield Mills BH - Mold Green - Huddersfield & 414660 & 416270 & Reticuloceras bilingue (R2b1-2) \\
\hline $\begin{array}{l}\text { Shale scar above right bank of River Derwent } \\
\text { about } 0.5 \mathrm{ml} \text { SW of Beeley }\end{array}$ & 425760 & 367010 & Reticuloceras bilingue (R2b1-2) \\
\hline Fairweather Green, Four Lane Ends, Bradford & 413410 & 433350 & Reticuloceras bilingue (R2b1-2) \\
\hline Saltaire $\mathrm{BH}-\mathrm{NW}$ of Bradford & 414100 & 438000 & Reticuloceras bilingue (R2b1-2) \\
\hline $\begin{array}{l}\text { 350yds SW of Lench House, Blackwood } \\
\text { Rishworth }\end{array}$ & 400700 & 417600 & $\begin{array}{l}\text { Reticuloceras reticulatum mut. } \\
\text { Beta (R2b1-2) }\end{array}$ \\
\hline $\begin{array}{l}\text { Pike Clough,300yds ENE of Pike Farm } \\
\text { Rishworth }\end{array}$ & 403210 & 417570 & Bilinguites bilinguis (R2b1-2) \\
\hline Upper Deanhead Clough, Scammonden & 402630 & 414540 & $\begin{array}{l}\text { Reticuloceras reticulatum mut. } \\
\text { Beta (R2b1-2) }\end{array}$ \\
\hline $\begin{array}{l}\text { Hard Head Clough - Shot Scar - ENE of March } \\
\text { Haigh Reservoir - Marsden }\end{array}$ & 402440 & 413250 & $\begin{array}{l}\text { Reticuloceras reticulatum mut. } \\
\text { Beta (R2b1-2) }\end{array}$ \\
\hline Old quarry,E side of Valley Road Slaithwaite & 408150 & 413470 & $\begin{array}{l}\text { Reticuloceras reticulatum mut. } \\
\text { Beta (R2b1-2) }\end{array}$ \\
\hline Slaithwaite Railway Station & 408160 & 415140 & $\begin{array}{l}\text { Reticuloceras reticulatum mut. } \\
\text { Beta (R2b1-2) }\end{array}$ \\
\hline $\begin{array}{l}\text { 600yds S 23degs W of Hooley Hey Farm, } 3 \\
\text { and 1/3rd miles SW of Taxal Church Cheshire }\end{array}$ & 397300 & 374810 & $\begin{array}{l}\text { Reticuloceras bilingue early form } \\
\text { (R2b1-2) }\end{array}$ \\
\hline Borehole at Phoenix Mills Huddersfield & 414940 & 417500 & $\begin{array}{l}\text { Reticuloceras reticulatum mut. bilingue } \\
\text { (R2b1-2) }\end{array}$ \\
\hline $\begin{array}{l}\text { Black Sike } 0.5 \mathrm{ml} \text { SW of Upperthong,1ml W of } \\
\text { Holmfirth }\end{array}$ & 412170 & 408080 & $\begin{array}{l}\text { Reticuloceras reticulatum mut. } \\
\text { Beta (R2b1-2) }\end{array}$ \\
\hline $\begin{array}{l}\text { SW end of Pule Hill,1150ft OD, 400yds NE of } \\
\text { Gilberts Farm W of Marsden }\end{array}$ & 403240 & 410160 & $\begin{array}{l}\text { Reticuloceras bilingue; } R \text {. reticulatum } \\
\text { mut. early Beta (R2b1-2) }\end{array}$ \\
\hline Kirk Lane Dyeworks BH & 420350 & 441020 & $\begin{array}{l}\text { Reticuloceras reticulatum early mut. } \\
\text { Beta (R2b1-2) }\end{array}$ \\
\hline $\begin{array}{l}\text { Wittonstall Clough, 500yds NE Cornholme } \\
\text { Station }\end{array}$ & 391480 & 426670 & $\begin{array}{l}\text { Reticuloceras reticulatum mut. Beta } \\
\text { (R2b1-2) }\end{array}$ \\
\hline $\begin{array}{l}\text { Paul Clough - Stiperden House - NE } \\
\text { Portsmouth Station }\end{array}$ & 390960 & 427920 & $\begin{array}{l}\text { Reticuloceras reticulatum mut. Beta } \\
\text { (R2b2) }\end{array}$ \\
\hline Bagnall & 393740 & 359230 & Bilinguites bilinguis ss. (R2b2) \\
\hline Greenway Hall Golf Course & 391860 & 351270 & Bilinguites bilinguis (R2b1) \\
\hline Middleton Towers & 340940 & 458660 & $\begin{array}{l}\text { Bilinguites sp. juv. (ex. gr. bilinguis) } \\
\text { (R2b1) }\end{array}$ \\
\hline Birchover Borehole,Buxton & 424130 & 362330 & Bilinguites bilinguis early form (R2b1) \\
\hline River Churnet north of Swainsmoor & 402410 & 361900 & $\begin{array}{l}\text { Bilinguites bilinguis early and type } \\
\text { (R2b1) }\end{array}$ \\
\hline Boreholes near Brund & 409630 & 361780 & $\begin{array}{l}\text { Bilinguites bilinguis early form and type } \\
\text { (R2b1\&2) }\end{array}$ \\
\hline
\end{tabular}




\begin{tabular}{|l|r|r|l|}
\hline & & & $\begin{array}{l}\text { Bilinguites bilinguis early form, } \\
\text { Hudsonoceras ornatum, Reticuloceras } \\
\text { sp. (R2b1) }\end{array}$ \\
\hline NE of Pilsley & 423260 & 371750 \\
\hline Newton Bank BH & 395820 & 395060 & Bilinguites bilinguis \\
\hline Park Clough, Hey Green, Marsden & 402990 & 412460 & Bilinguites bilinguis early form (R2b1) \\
\hline NW of Black Bank & 375750 & 464800 & Bilinguites bilinguis \\
\hline Sabden Brook & 374600 & 434300 & Reticuloceras bilingue \\
\hline Aire Valley BH 26 & 410190 & 439500 & Bilinguites bilinguis \\
\hline Snail Green BH & 411800 & 442500 & Reticuloceras bilingue \\
\hline Horsforth Water Works BH SE24SW/7a & 423370 & 441160 & Reticuloceras bilingue \\
\hline Red Brook 914m WNW of Lydgate Mill & 396160 & 416650 & Bilinguites bilinguis, B. cf. circumplicatile \\
\hline
\end{tabular}

\begin{tabular}{|c|c|c|c|}
\hline LOCALITY & EASTING & $\begin{array}{l}\text { NORTHIN } \\
\text { G }\end{array}$ & AMMONOIDS \\
\hline \multicolumn{4}{|l|}{ Bilinguites bilinguis Marine Band (R2b1-3) Continued } \\
\hline $\begin{array}{l}\text { Moorley Clough 183m S of Rough Stones } \\
\text { Farm }\end{array}$ & 394070 & 420490 & Bilinguites bilinguis, $B$. cf. circumplicatile \\
\hline 557m S31E of Cowall, Cowall Manor & 390690 & 355160 & Bilinguites bilinguis (R2b1-2) \\
\hline Broomhead Reservoir dam trench & 426880 & 396000 & $\begin{array}{l}\text { Reticuloceras reticulatum mut. Beta } \\
\text { (R2b1-2) }\end{array}$ \\
\hline Trumfleet No $2 \mathrm{BH}$ & 460330 & 412460 & Bilinguites bilinguis \\
\hline Whitehall Works BH & 403550 & 382020 & Reticuloceras bilingue early form (R2b1) \\
\hline Forge Works No. $3 \mathrm{BH}$ & 404170 & 382190 & Reticuloceras bilingue early form (R2b1) \\
\hline Blackedge Reservoir & 406730 & 376550 & Reticuloceras bilingue (R2b1) \\
\hline Hogshaw Brook & 405990 & 374230 & $\begin{array}{l}\text { Reticuloceras bilingue early form \& } \\
\text { bilingue (R2b1\&2) }\end{array}$ \\
\hline Stream 0.25 miles ESE of Longhill Farm & 403790 & 374830 & Reticuloceras bilingue (R2b1) \\
\hline Stream near Dunge Farm & 398930 & 377680 & Reticuloceras bilingue early form (R2b1) \\
\hline Broughton Brook waterfall & 331970 & 361590 & Bilinguites cf. bilinguis (R2b2) \\
\hline Heaton, 300 yds $N$ by E Bearda & 6320 & 364510 & Reticuloceras bilingue (R2b2) \\
\hline $\begin{array}{l}\text { Heaton, } S \text { bank of R. Deane, } 350 \text { yds } W \text { by } N \\
\text { Hollinhall }\end{array}$ & 395380 & 363880 & Reticuloceras bilinque (R2b2) \\
\hline $\begin{array}{l}\text { Heaton, } S \text { bank of R. Deane, } 450 \text { yds NE by } E \\
\text { Wormhill }\end{array}$ & 394120 & 363490 & Reticuloceras bilingue early form (R2b1) \\
\hline $\begin{array}{l}\text { Rushton, Dingle Brook, } 500 \text { yds W by S Fold } \\
\text { Farm }\end{array}$ & 392610 & 361330 & Reticuloceras bilingue early form (R2b1) \\
\hline Heaton, 500 yds NE by N Fairboroughs & 396020 & 361270 & Reticuloceras bilingue \\
\hline Horton, 320 yds SE Endon Hays & 393100 & 360470 & Reticuloceras bilingue early form (R2b1) \\
\hline Biddulph, 240 yds ESE Heath Hay & 390720 & 359180 & Reticuloceras bilingue \\
\hline $\begin{array}{l}\text { Beeley Brook, } 570 \text { yds S66E of St Anne's } \\
\text { Church, Beeley }\end{array}$ & 426980 & 367450 & Reticuloceras bilingue (R2b2) \\
\hline $\begin{array}{l}\text { Lindup Wood, } 1050 \text { yds S48W of St Anne's } \\
\text { Church, Beeley }\end{array}$ & 425790 & 367000 & Reticuloceras bilingue (R2b2) \\
\hline $\begin{array}{l}\text { Ravensnest Wood, } 770 \text { yds N82W of Raven } \\
\text { House }\end{array}$ & 434530 & 361270 & Reticuloceras bilingue (R2b2) \\
\hline Hole Wood, 530 yds S9W of Raven House & 435160 & 360670 & Reticuloceras bilingue (R2b2) \\
\hline Tansley BH - Derbyshire & 433126 & 359604 & Reticuloceras bilingue early form (R2b1) \\
\hline Uppertown BH - Derbyshire & 2370 & 364250 & Reticuloceras bilingue early form (R2b1) \\
\hline South of Cheddleton & 397980 & 350230 & Reticuloceras bilingue early form (R2b1) \\
\hline Cotton Dell & 406120 & 346080 & Reticuloceras bilingue ss. (R2b2) \\
\hline Lumb Grange & 433140 & 346750 & Reticuloceras bilinguis \\
\hline Croxteth Park BH & 340300 & 394300 & Reticuloceras bilingue (R2b2) \\
\hline $\begin{array}{l}\text { Head of Doe Holes Clough,200yds above } \\
\text { Deanhead Clough, Scammonden }\end{array}$ & 402910 & 414930 & Reticuloceras reticulatum mut. Beta \\
\hline Crimble Clough - Slaithwaite - Yorkshire & 408160 & 415110 & Reticuloceras reticulatum (R2b2) \\
\hline Clark Bridge Mills BH - Halifax & 409846 & 425166 & Reticuloceras reticulatum \\
\hline $\begin{array}{l}\text { Old quarry - Varley Road/Mansergh House - } \\
\text { Slaithwaite }\end{array}$ & 408150 & 413470 & Reticuloceras reticulatum \\
\hline $\begin{array}{l}\text { Stream - 0.5ml NE of Warders Tower - } \\
\text { Knypersley Reservoir - Crowborough Wood }\end{array}$ & 390670 & 355180 & Reticuloceras reticulatum \\
\hline Worthington BH SK24SW/204 & 440450 & 321040 & Bilinguites sp., B. bilinguis (R2b1) \\
\hline Asfordby Hydro BH SK72SW/71 & 472520 & 320610 & Bilinguites cf. bilingue \\
\hline \multicolumn{4}{|l|}{ Bilinguites eometabilinguis Marine Band (R2b4) } \\
\hline South of Stake Gutter & & 362980 & Bilinguites eometabilinguis \\
\hline & & 362330 & Bilinguites eometabilinguis \\
\hline Nan Scar Beck - Sunny Bank - Yorkshire & 403400 & 433300 & Reticuloceras reticulatum late mut. Beta \\
\hline
\end{tabular}




\begin{tabular}{|c|c|c|c|}
\hline Gingerbread Clough & 406100 & 439500 & Reticuloceras reticulatum \\
\hline Cullingworth, Hewenden Valley & 407820 & 436120 & Reticuloceras reticulatum late mut. Beta \\
\hline $\begin{array}{l}\text { Stream, } 500 \text { yds SE Lion's Paw Farm, } \\
\text { Knypersley }\end{array}$ & 390300 & 355600 & $\begin{array}{l}\text { Bilinguites eometabilinguis, B. bilinguis } \\
\text { late form }\end{array}$ \\
\hline Cotton Dell & 406120 & 345770 & $\begin{array}{l}\text { Reticuloceras eometabilingue, } R \text {. } \\
\text { metabilingue }\end{array}$ \\
\hline Carsington Aquaduct BH M8 SK25SE/62 & 425390 & 350190 & $\begin{array}{l}\text { Reticuloceras eometabilingue, } R \text {. } \\
\text { bilingue }\end{array}$ \\
\hline LOCALITY & EASTING & $\begin{array}{l}\text { NORTHIN } \\
\text { G }\end{array}$ & AMMONOIDS \\
\hline \multicolumn{4}{|c|}{ Bilinguites eometabilinguis Marine Band (R2b4) Continued } \\
\hline Asfordby Hydro BH SK72SW/71 & 472520 & 320610 & Bilinguites cf. eometabilingue \\
\hline \multicolumn{4}{|l|}{ Bilinguites metabilinguis Marine Band (R2b5) } \\
\hline Phoenix Mills BH Huddersfield & 414940 & 317500 & $\begin{array}{l}\text { Reticuloceras reticulatum cf. mut. } \\
\text { metabilingue }\end{array}$ \\
\hline $\begin{array}{l}\text { 300yds NE of Higher Hempshaws - 2mls W of } \\
\text { Belmont }\end{array}$ & 365000 & 416500 & $\begin{array}{l}\text { Reticuloceras eometabilingue, } \\
\text { Reticuloceras reticulatum metabilingue }\end{array}$ \\
\hline $\begin{array}{l}\text { Fairweather Green BH, Four Lane Ends, } \\
\text { Bradford }\end{array}$ & 413380 & 433300 & Reticuloceras bilingue late form \\
\hline Horsforth UD Waterworks $\mathrm{BH}$ - N of Horsforth & 423370 & 441160 & Reticuloceras reticulatum late mut. Beta \\
\hline Bagnall & 393640 & 350530 & $\begin{array}{l}\text { Bilinguites cf. metabilinguis Verneulites } \\
\text { sigma }\end{array}$ \\
\hline Birchover Borehole, Buxton SK26SW/16 & 424130 & 362330 & Bilinguites metabilinguis \\
\hline Brownsett & 399250 & 363690 & Bilinguites metabilinguis \\
\hline Aire Valley BH P22 SE03NE/9 & 409850 & 439750 & Bilinguites bilinguis late form \\
\hline Aire Valley BH A4 SE04SE/15 & 408920 & 440560 & Bilinguites bilinguis late form \\
\hline Aire Valley BH A1 SE04SE/12 & 408820 & 440360 & $\begin{array}{l}\text { Bilinguites bilinguis late form, cf. } B . \\
\text { metabilinguis }\end{array}$ \\
\hline $\begin{array}{l}200 \text { yards ESE of Mould Greave, Marsh, near } \\
\text { Oxenhope }\end{array}$ & 402700 & 435400 & Reticuloceras reticulatum late mut. Beta \\
\hline $\begin{array}{l}\text { Lees Moor BH, } 230 \text { yards W of Lower Height } \\
\text { Bingley }\end{array}$ & 406100 & 438000 & Reticuloceras reticulatum late mut. Beta \\
\hline Kirk Lane Dyeworks BH SE24SW/4a & 420350 & 441020 & Reticuloceras reticulatum late mut Beta \\
\hline $\begin{array}{l}\text { Old lead mines } 0.5 \text { miles } E \text { of Leicester Mill } \\
\text { Quarry }\end{array}$ & 362830 & 416360 & $\begin{array}{l}\text { Reticuloceras metabilingue, } \\
\text { Gastrioceras sigma }\end{array}$ \\
\hline $\begin{array}{l}\text { Ryal Fold, W of Darwen Hill } 280 \text { yards SSE of } \\
\text { the SE end of Higher Roddlesworth Reservoir }\end{array}$ & 366200 & 421520 & Reticuloceras metabilingue \\
\hline Wiggins Teape No2 $\mathrm{BH}$ & 361460 & 423440 & Reticuloceras metabilingue \\
\hline Star Paper Mills B BH & 364700 & 424950 & Reticuloceras metabilingue \\
\hline 400 yds N16W of Ladymon (?Ladymoor) Gate & 390300 & 355800 & $\begin{array}{l}\text { Bilinguites metabilinguis, } B \text {. bilinguis late } \\
\text { form }\end{array}$ \\
\hline South end of tunnel, Scout, Scout Mill & 397280 & 401230 & $\begin{array}{l}\text { Reticuloceras reticulatum late mut. B \& } \\
\text { gamma }\end{array}$ \\
\hline $\begin{array}{l}\text { Stream } 140 \text { yds WNW of Carr Meadow, } \\
\text { Derbyshire }\end{array}$ & 403320 & 389510 & Reticuloceras metabilingue \\
\hline Stream W of Marl House, Derbyshire & 403090 & 388800 & $\begin{array}{l}\text { Reticuloceras cf. bilingue late form, } R \text {. } \\
\text { metabilingue }\end{array}$ \\
\hline Blackedge Reservoir & 406730 & 376550 & Reticuloceras metabilingue \\
\hline $\begin{array}{l}\text { Rocher End Brook, 420yds at N50W from } \\
\text { Bradfield Church }\end{array}$ & 426000 & 392000 & $\begin{array}{l}\text { Reticuloceras bilingue late form, } \\
\text { Homoceras? }\end{array}$ \\
\hline $\begin{array}{l}\text { Rivelin valley close to Wolf Wheel } 1160 \text { yds } \\
\text { S83E of Rails }\end{array}$ & 430200 & 387500 & Reticuloceras bilingue late form \\
\hline $\begin{array}{l}\text { Macclesfield Forest, S bank of reservoir, } 1400 \\
\text { yds NE Thickwithers }\end{array}$ & 396570 & 371300 & Reticuloceras metabilingue \\
\hline Rushton, 350 yds NE Oulton & 396570 & 371300 & Reticuloceras metabilingue \\
\hline $\begin{array}{l}\text { Lindup Wood, } 1050 \text { yds S48W of St Anne's } \\
\text { Church, Beeley }\end{array}$ & 425790 & 367000 & Reticuloceras bilingue late form \\
\hline 370 yds S75E of Cromford station & 430650 & 357280 & Reticuloceras bilingue late form \\
\hline South of Cheddleton & 398130 & 350430 & Reticuloceras bilingue late form \\
\hline Combes Valley & 400360 & 351450 & $\begin{array}{l}\text { Reticuloceras metabilingue and } R \text {. } \\
\text { bilingue early form }\end{array}$ \\
\hline Duffield railway cutting & 434290 & 343640 & Reticuloceras bilinguis late form \\
\hline Ferriby Brook & 438080 & 339780 & Reticuloceras bilinguis late form \\
\hline $\begin{array}{l}\text { Butts Clough - 220yds SW Clough Head Farm } \\
\text { - Rishworth }\end{array}$ & 404300 & 417810 & Reticuloceras reticulatum mut. Beta \\
\hline $\begin{array}{l}\text { Blake Clough - Blake Clough Farm - } \\
\text { Slaithwaite Moors }\end{array}$ & 405200 & 413610 & Reticuloceras reticulatum mut. Beta \\
\hline Worthington BH SK24SW/204 & 440450 & 321040 & $\begin{array}{l}\text { Bilinguites sp., B. bilinguis, } B \text {. } \\
\text { metabilinguis }\end{array}$ \\
\hline
\end{tabular}




\begin{tabular}{|c|c|c|c|}
\hline Asfordby Hydro BH SK72SW/71 & 472520 & 320610 & Bilinguites sp. \\
\hline \multicolumn{4}{|l|}{ Bilinguites superbilinguis Marine Band (R2c1) } \\
\hline $\begin{array}{l}\text { Pears House Clough, 850yds S of Strines } \\
\text { Public House - Derbyshire }\end{array}$ & 422520 & 389890 & Reticuloceras superbilingue \\
\hline $\begin{array}{l}\text { Eagle Stone - site 825yds from at S5W- 8mls } \\
\text { NNW of Chesterfield }\end{array}$ & 426000 & 373000 & $\begin{array}{l}\text { Reticuloceras reticulatum mut. } \\
\text { superbilingue }\end{array}$ \\
\hline $\begin{array}{l}\text { Rocher End Brook,530yds at 344degs from } \\
\text { Bradfield Church, Yorkshire }\end{array}$ & 426000 & 392000 & $\begin{array}{l}\text { Reticuloceras superbilinguis, } \\
\text { Gastrioceras sp. nov., G. cf. lineatum, } \\
\text { Homoceratoides cf. divaricatus, } H \text {, sp. } \\
\text { nov. }\end{array}$ \\
\hline LOCALITY & EASTING & $\begin{array}{l}\text { NORTHIN } \\
\text { G }\end{array}$ & AMMONOIDS \\
\hline \multicolumn{4}{|c|}{ Bilinguites superbilinguis Marine Band (R2c1) Continued } \\
\hline Newton Bank BH & 395820 & 395060 & Bilinguites superbilinguis \\
\hline Will Moor Clough, 240 yards S of Antley Gate & 391900 & 436300 & Reticuloceras superbilingue \\
\hline Trawden Brook, below Lumb Spout Waterfall & 392000 & 437200 & Reticuloceras superbilingue \\
\hline Aire Valley BH A1SE04SE/12 & 408820 & 440360 & Bilinguites ghosts \\
\hline Horsforth Water Works BH SE24SW/7a & 423370 & 441160 & Reticuloceras superbilingue \\
\hline $\begin{array}{l}\text { Haworth Moor at Near Fosse Intake } 170 \text { yards } \\
\text { ESE of Withins }\end{array}$ & 398300 & 435400 & Reticuloceras reticulatum mut. gamma \\
\hline Blue Scar Beck 550 yards NNE of Clough Hey & 400000 & 439900 & Reticuloceras reticulatum mut. gamma \\
\hline $\begin{array}{l}\text { Baildon Holmes } 1100 \text { yards S67E of Baildon } \\
\text { Green church }\end{array}$ & 415400 & 438200 & Reticuloceras reticulatum mut. gamma \\
\hline Sydney Works BH, Fairweather Green & 413400 & 433300 & Reticuloceras superbilingue \\
\hline Sandoz Chemical Co. BH & 416300 & 434300 & Reticuloceras superbilingue \\
\hline New Lane Mills BH Laisterdyke & 419100 & 432700 & Reticuloceras superbilingue \\
\hline River Yarrow 300 yards NE of Hempshaws & 365000 & 416500 & $\begin{array}{l}\text { Reticuloceras superbilingue, } \\
\text { Gastrioceras sigma }\end{array}$ \\
\hline Ryal Fold, west of Darwen Hill & 366260 & 421700 & Reticuloceras superbilingue \\
\hline Wiggins Teape No2 BH Withnell Fold & 361460 & 423440 & Reticuloceras superbilingue \\
\hline Mossley Sewage Works 450 yards S of Scout & 397200 & 400800 & Reticuloceras reticulatum mut. gamma \\
\hline Askern Oil BH SE51NE/1 & 456520 & 415020 & Bilinguites superbilinguis \\
\hline Moss Oil BH SE51SE/19 & 459980 & 413900 & Bilinguites superbilinguis \\
\hline Trumfleet No $1 \mathrm{BH}$ & 460520 & 412640 & Bilinguites superbilinguis \\
\hline Trumfleet No $2 \mathrm{BH}$ & 460330 & 412460 & $\begin{array}{l}\text { Bilinguites superbilinguis, Verneulites } \\
\text { sigma }\end{array}$ \\
\hline Tributary of Long Clough, Derbyshire & 402710 & 390980 & $\begin{array}{l}\text { Reticuloceras superbilingue, } \\
\text { Donetzoceras cf. sigma, Gastrioceras, } \\
\text { Homoceratoides cf. divaricatus }\end{array}$ \\
\hline Heylee, Spire Hollins & 403200 & 378300 & $\begin{array}{l}\text { Reticuloceras superbilingue, } \\
\text { Gastrioceras spp., Homoceratoides } \\
\text { divaricatus }\end{array}$ \\
\hline Pyegreave Brook & 404880 & 378060 & Reticuloceras superbilingue \\
\hline Castle Naze & 404820 & 378570 & $\begin{array}{l}\text { Reticuloceras superbilingue, } \\
\text { Gastrioceras spp., Homoceratoides } \\
\text { fortelirifer }\end{array}$ \\
\hline Lightwood Reservoir & 405470 & 375290 & Reticuloceras sp. \\
\hline Yarncliff Wood & 425140 & 379100 & $\begin{array}{l}\text { Donetzoceras sigma, Reticuloceras } \\
\text { superbilinguis }\end{array}$ \\
\hline Hallam Head BH & 430091 & 389123 & $\begin{array}{l}\text { Donetzoceras sigma, Reticuloceras } \\
\text { superbilinguis }\end{array}$ \\
\hline Broughton Brook, SE of Corn Mill & 331640 & 365410 & Bilinguites superbilinguis \\
\hline $\begin{array}{l}\text { Sutton, } 500 \text { yds NE by } \mathrm{N} \text { of Langley Print } \\
\text { Works }\end{array}$ & 394350 & 371740 & Reticuloceras superbilingue \\
\hline Uppertown $\mathrm{BH}$ - Derbyshire & 432370 & 364250 & Reticuloceras bilingue early form \\
\hline 3050 yds N5E of Chatsworth House & 426510 & 373030 & $\begin{array}{l}\text { Reticuloceras superbilingue, } \\
\text { Gastrioceras spp. Homoceratoides } \\
\text { fortelirifer }\end{array}$ \\
\hline $\begin{array}{l}\text { Jumbel (or Jumble) Coppice - Baslow; } 2230 \\
\text { yds N25E of Chatsworth House }\end{array}$ & 426830 & 372090 & $\begin{array}{l}\text { Reticuloceras superbilingue, } \\
\text { Gastrioceras spp. Homoceratoides } \\
\text { fortelirifer }\end{array}$ \\
\hline Bassetbarn Farm BH & 435540 & 364160 & Reticuloceras superbilingue \\
\hline Bothamsall No $1 \mathrm{BH}$ & 465860 & 373675 & Reticuloceras cf. superbilingue \\
\hline Shirley Hollow & 403790 & 348090 & Reticuloceras superbilingue \\
\hline Rotherwood BH & 434580 & 315590 & Bilinguites superbilinguis \\
\hline W. of Hankin Farm & 432140 & 354480 & Reticuloceras superbilingue \\
\hline Ambergate railway cutting & 434670 & 350800 & Reticuloceras superbilingue \\
\hline Blackfordby No. $1 \mathrm{BH}$ & 432250 & 318270 & Reticuloceras reticulatum mut. gamma \\
\hline Bottonley Clough - 140yds E of Bottoms Farm & 406340 & 419190 & Reticuloceras reticulatum \\
\hline
\end{tabular}




\begin{tabular}{|c|c|c|c|}
\hline - Barkisland & & & \\
\hline $\begin{array}{l}\text { Junction of Streams - Heath House Wood - } \\
\text { 150yds N of Heath House - Golcar }\end{array}$ & 408990 & 415810 & Reticuloceras reticulatum \\
\hline $\begin{array}{l}\text { Stream bank below Haslingden-Helmshore } \\
\text { Road - 850yds NW of Helmshore Sation }\end{array}$ & 377760 & 421680 & Reticuloceras reticulatum \\
\hline Worthington BH SK24SW/204 & 440450 & 321040 & $\begin{array}{l}\text { Bilinguites superbilinguis, Gastrioceras } \\
\text { sp. }\end{array}$ \\
\hline Asfordby Hydro BH SK72SW/71 & 472520 & 320610 & $\begin{array}{l}\text { Bilinguites superbilinguis, } \\
\text { cf.Gastrioceras sp. }\end{array}$ \\
\hline \multicolumn{4}{|l|}{ Verneulites sigma Marine Band (R2c2) } \\
\hline Oxspring Borehole, SE of Oxspring SE20SE/6 & 427870 & 401360 & $\begin{array}{l}\text { Gastrioceras ? sigma, Reticuloceras } \\
\text { reticulatum mut. superbilingue }\end{array}$ \\
\hline LOCALITY & EASTING & $\begin{array}{l}\text { NORTHIN } \\
\text { G }\end{array}$ & AMMONOIDS \\
\hline \multicolumn{4}{|l|}{ Verneulites sigma Marine Band (R2c2) Continued } \\
\hline Stream bank, NNW of Bromiley, Belmont & 365780 & 417920 & Gastrioceras sigma \\
\hline NE of Higher Hempshaws, $W$ of Belmont & 365000 & 416500 & Gastrioceras ? sigma \\
\hline Burbage Brook, Grindleford Station, Derbys. & 425030 & 378690 & Gastrioceras ? sigma \\
\hline $100 y d s \mathrm{~N}$ of Chatsworth House & 426210 & 371180 & Gastrioceras ? sigma \\
\hline Anglezarke Reservoir, Lancashire & 362200 & 415900 & Gastrioceras sigma, Homoceratoides \\
\hline Ryal Fold, west of Darwen Hill & 366300 & 421490 & Pygmaeoceras sigma \\
\hline Wiggins Teape No2 BH & 361460 & 423440 & Gastrioceras sp. \\
\hline 200 yards SE of Canyards & 425900 & 395100 & $\begin{array}{l}\text { Reticuloceras reticulatum early mut. } \\
\text { gamma }\end{array}$ \\
\hline Raynor Clough 800 yds E25N of White Lea & 427500 & 395500 & $\begin{array}{l}\text { Reticuloceras reticulatum early mut. } \\
\text { gamma, Gastrioceras? sigma }\end{array}$ \\
\hline $\begin{array}{l}\text { More Hall (or Hull) Reservoir - trial hole for } \\
\text { wing trench - 900yds NW of Brightholmlee }\end{array}$ & 428390 & 395570 & $\begin{array}{l}\text { Gastrioceras cf. cumbriense, G. cf. } \\
\text { crenulatum, G. spp, Reticuloceras } \\
\text { reticulatum mut. gamma, Gastrioceras? } \\
\text { sigma }\end{array}$ \\
\hline Stream N of Bankvale Mill & 403110 & 387660 & $\begin{array}{l}\text { Donetzoceras sigma, Reticuloceras } \\
\text { superbilingue }\end{array}$ \\
\hline River between Strines \& Dale Dike reservoirs & 423360 & 390660 & Donetzoceras sigma \\
\hline Pear House Clough & 422830 & 388960 & Donetzoceras sigma \\
\hline Callow Bank & 425190 & 382290 & Donetzoceras sigma \\
\hline Yarncliff Wood & 425140 & 379100 & Donetzoceras sigma \\
\hline Wincle, 1300 yds SE Sutton End & 396630 & 367980 & Donetzoceras sigma \\
\hline Rushton, 810 yds SE by $\mathrm{E}$ of The Cloud & 391060 & 363200 & Donetzoceras sigma \\
\hline Biddulph, 180 yds S by W of Heath Hay & 390480 & 359110 & Donetzoceras sigma \\
\hline Biddulph, 400 yds NNW of Cowall & 390250 & 356030 & Donetzoceras sigma \\
\hline 3050 yds N5E of Chatsworth House & 426150 & 373030 & Pygmaeoceras sigma \\
\hline 2230 yds N25E of Chatsworth House & 426830 & 372090 & Pygmaeoceras sigma, Gastrioceras sp. \\
\hline Bassetbarn Farm BH & 435540 & 364160 & $\begin{array}{l}\text { Pygmaeoceras sigma, Gastrioceras sp., } \\
\text { Reticuloceras superbilingue }\end{array}$ \\
\hline Combes Valley & 401350 & 351010 & Donetzoceras sigma \\
\hline Shirley Hollow & 403790 & 348090 & Donetzoceras sigma \\
\hline Blackfordby No. $1 \mathrm{BH}$ & 432350 & 318270 & Gastrioceras ?sigma \\
\hline \multicolumn{4}{|l|}{ Cancelloceras cancellatum Marine Band (G1a1) } \\
\hline Royshaw Brick Works, Blackburn Station & 368250 & 429500 & $\begin{array}{l}\text { Gastrioceras cancellatum var. } \\
\text { crencellatum; Reticuloceras reticulatum }\end{array}$ \\
\hline $\begin{array}{l}\text { Section in Dean brook,150yds S of Higher } \\
\text { House, } 2 \text { miles W of Belmont }\end{array}$ & 364350 & 415380 & $\begin{array}{l}\text { Gastrioceras cancellatum, G. cf. } \\
\text { crencellatum, } R \text {. superbilingue }\end{array}$ \\
\hline Crowborough Wood Warders Tower,Staffs. & 390100 & 355520 & Gastrioceras cf. cancellatum \\
\hline Nant Figillt Farm - Rhosesmor - Flints & 320910 & 368000 & $\begin{array}{l}\text { Cancelloceras cancellatum, C. } \\
\text { crencellatum, C. sp., Homoceratoides } \\
\text { divaricatum, Reticuloceras reticulatum } \\
\text { mut alpha }\end{array}$ \\
\hline Wall Grange Brick Pit - Staffs. & 396440 & 353220 & Gastrioceras cancellatum \\
\hline Bowsey Wood BH SJ74NE/9 & 376950 & 346430 & Gastrioceras cf. cancellatum \\
\hline Heysham Power Station BH SD45NW/87 & 340260 & 459940 & $\begin{array}{l}\text { Cancelloceras cancellatum, C. } \\
\text { crencellatum, C. sp., Homoceratoides } \\
\text { divaricatum, Reticuloceras reticulatum } \\
\text { mut alpha }\end{array}$ \\
\hline Seat Hall BH SD66NE/2 & 366030 & 469820 & $\begin{array}{l}\text { Cancelloceras cancellatum, } \\
\text { C.branneroides }\end{array}$ \\
\hline River Greta & 361700 & 472230 & $\begin{array}{l}\text { Gastrioceras cf. cancellatum, } \mathrm{C} \text {. } \\
\text { crencellatum }\end{array}$ \\
\hline Newton Bank BH & 395820 & 395060 & Gastrioceras crencellatum \\
\hline Harrop Brook & 395990 & 378460 & Gastrioceras crencellatum \\
\hline
\end{tabular}




\begin{tabular}{|c|c|c|c|}
\hline Bollington Print Works $\mathrm{BH}$ & 393980 & 377970 & Gastrioceras cancellatum \\
\hline Orchard Farm & 402260 & 369030 & Cancelloceras cancellatum \\
\hline Waters Farm BH & 375370 & 467630 & $\begin{array}{l}\text { Cancelloceras cancellatum, } \\
\text { Gastrioceras crencellatum, G. } \\
\text { branneroides }\end{array}$ \\
\hline Farnham BH SE35NE/27 & 434690 & 459960 & $\begin{array}{l}\text { Cancelloceras cf. cancellatum, } \\
\text { C. crencellatum }\end{array}$ \\
\hline Monkroyd Beck, NNE of Monkroyd & 393400 & 441400 & Gastrioceras crencellatum \\
\hline Aire Valley $\mathrm{BH} 28$ SE13NW/22 & 410400 & 439110 & $\begin{array}{l}\text { Cancelloceras cancellatum, } \\
\text { C. crencellatum }\end{array}$ \\
\hline Aire Valley BH B52 SE13NE/29 & 415010 & 437880 & $\begin{array}{l}\text { Cancelloceras cancellatum, } \\
\text { C. crencellatum }\end{array}$ \\
\hline Aire Valley BH A2 SE04SE/13 & 408870 & 440450 & Cancelloceras crencellatum \\
\hline LOCALITY & EASTING & $\begin{array}{l}\text { NORTHIN } \\
\text { G }\end{array}$ & AMMONOIDS \\
\hline \multicolumn{4}{|c|}{ Cancelloceras cancellatum Marine Band (G1a1) Continued } \\
\hline Horsforth Water Works BH SE04SE/13 & 423370 & 441160 & Cancelloceras cancellatum \\
\hline $\begin{array}{l}\text { Middle Moor Clough } 600 \text { yards SW of Upper } \\
\text { Ponden }\end{array}$ & 397600 & 436000 & $\begin{array}{l}\text { Cancelloceras cancellatum, } \\
\text { Gastrioceras crencellatum, } R \text {. } \\
\text { superbilinguis }\end{array}$ \\
\hline Bingley Brick Pit & 411200 & 441200 & $\begin{array}{l}\text { Cancelloceras cancellatum, } R \text {. } \\
\text { superbilinguis }\end{array}$ \\
\hline Saltaire Mills & 414100 & 438000 & $\begin{array}{l}\text { Cancelloceras cancellatum, } R \text {. } \\
\text { superbilinguis }\end{array}$ \\
\hline Yeadon Brick \& Tile Works & 419400 & 440900 & $\begin{array}{l}\text { Cancelloceras cancellatum, } R \text {. } \\
\text { superbilinguis }\end{array}$ \\
\hline $\begin{array}{l}\text { West View, } 330 \text { yards N of Apperley Bridge } \\
\text { Station }\end{array}$ & 419600 & 438700 & $\begin{array}{l}\text { Cancelloceras cancellatum, } R . \\
\text { superbilinguis }\end{array}$ \\
\hline Sydney Works BH, Fairweather Green & 413400 & 433300 & $\begin{array}{l}\text { Cancelloceras cancellatum, } \\
\text { Gastrioceras crencellatum, ? G. sigma }\end{array}$ \\
\hline New Lane Mills Laisterdyke & 419100 & 432700 & $\begin{array}{l}\text { Gastrioceras crencellatum, G. cf. } \\
\text { cumbriense }\end{array}$ \\
\hline Summit Brickworks & 394850 & 418730 & $\begin{array}{l}\text { Gastrioceras crencellatum, } \\
\text { Cancelloceras cancellatum }\end{array}$ \\
\hline Ring road cutting $\mathrm{N}$ of Meanwood Hall & 428300 & 438600 & Gastrioceras cancellatum type \\
\hline $\begin{array}{l}60 \text { yds WNW of Hollinshead Hall } 3 \text { miles } \mathrm{N} \text { of } \\
\text { Belmont }\end{array}$ & 366230 & 419920 & Gastrioceras crencellatum (upper fauna) \\
\hline 400 yds N10W of Wheelton crossroads & 359990 & 421510 & $\begin{array}{l}\text { Gastrioceras branneroides (Bed A), G. } \\
\text { cancellatum, R. superbilingue (Bed B- } \\
\text { C), G. crencellatum (Bed D) }\end{array}$ \\
\hline $\begin{array}{l}\text { Howe Brook, SW of Chorley } 1560 \text { yds NNW of } \\
\text { Wrightington Church }\end{array}$ & 352030 & 414860 & Gastrioceras crencellatum (upper fauna) \\
\hline Acres Brook & 397000 & 397800 & $\begin{array}{l}\text { Gastrioceras cancellatum, } R \text {. } \\
\text { reticulatum mut. gamma }\end{array}$ \\
\hline Oxspring BH, SE of Oxspring SE20SE/6 & 427870 & 401360 & $\begin{array}{l}\text { Gastrioceras cancelloceras, } \\
\text { Reticuloceras reticulatum mut. gamma }\end{array}$ \\
\hline Trumfleet No 1 BH SE51SE/1 & 460520 & 412640 & $\begin{array}{l}\text { Cancelloceras cancellatum, } \mathrm{C} . \\
\text { crencellatum }\end{array}$ \\
\hline Askern Oil BH SE51NE/1 & 456520 & 415020 & Cancelloceras crencellatum \\
\hline Belton Oil BH & 477710 & 408460 & Cancelloceras crencellatum \\
\hline Fernilee No. $1 \mathrm{BH}$ & 401240 & 378230 & $\begin{array}{l}\text { Cancelloceras cancellatum, } C . \\
\text { crencellatum, } R \text {. superbilingue }\end{array}$ \\
\hline Mather Clough & 397700 & 382130 & $\begin{array}{l}\text { Cancelloceras cancellatum, C. cf. } \\
\text { crencellatum }\end{array}$ \\
\hline Mill Clough & 400240 & 378070 & Cancelloceras crencellatum \\
\hline Shooter's Clough & 400570 & 374670 & $\begin{array}{l}\text { Cancelloceras cancellatum, } R . \\
\text { superbilingue }\end{array}$ \\
\hline Damflask Reservoir & 427400 & 391100 & $\begin{array}{l}\text { Gastrioceras cancellatum, G. cf. } \\
\text { crencellatum, Reticuloceras } \\
\text { superbilinguis }\end{array}$ \\
\hline Rod Moor No $3 \mathrm{BH}$ & 426780 & 389160 & $\begin{array}{l}\text { Gastrioceras crencellatum, } \\
\text { Reticuloceras superbilinguis }\end{array}$ \\
\hline $\begin{array}{l}\text { Carr Brook, } 1490 \text { yds N79E of Bassett, W of } \\
\text { Fulwood }\end{array}$ & 429700 & 384800 & Gastrioceras crencellatum, G. rurae \\
\hline $\begin{array}{l}\text { Limb Brook, } 1250 \text { yds N88E of Barberfields } \\
\text { Farm }\end{array}$ & 430800 & 382900 & Gastrioceras cf. cancellatum, G. rurae? \\
\hline Smeekley No 3 BH & 429690 & 376498 & $\begin{array}{l}\text { Gastrioceras cancellatum, } G . \\
\text { crencellatum }\end{array}$ \\
\hline Tickhill No $1 \mathrm{BH}$ & 457730 & 392970 & Gastrioceras cancellatum \\
\hline Walkeringham No $1 \mathrm{BH}$ & 475550 & 391900 & Gastrioceras crencellatum \\
\hline
\end{tabular}




\begin{tabular}{|c|c|c|c|}
\hline Morton No $1 \mathrm{BH}$ & 479320 & 392410 & Gastrioceras crencellatum \\
\hline Apleyhead No $1 \mathrm{BH}$ & 465510 & 376310 & Gastrioceras cf. crencellatum \\
\hline Apleyhead No 2 BH & 465770 & 376630 & Gastrioceras cf. crencellatum \\
\hline Bothamsall No $2 \mathrm{BH}$ & 465566 & 373917 & Gastrioceras crencellatum \\
\hline Bothamsall No $4 \mathrm{BH}$ & 466193 & 374022 & Gastrioceras crencellatum \\
\hline Fishpond Wood, stream section & 332600 & 364310 & Cancelloceras cancellatum \\
\hline Warren Dingle & 331790 & 362340 & $\begin{array}{l}\text { Cancelloceras cancellatum, Ca. } \\
\text { branneroides, Ca. sp., Bilinguites } \\
\text { superbilinguis }\end{array}$ \\
\hline $\begin{array}{l}\text { Congleton, } 660 \text { yds NE by E of Timbersbrook } \\
\text { crossroads }\end{array}$ & 390030 & 362980 & $\begin{array}{l}\text { Cancelloceras cancellatum, Bilinguites } \\
\text { superbilinguis, Homoceratoides sp. }\end{array}$ \\
\hline Biddulph, 300 yds WSW of Heath Hay & 390260 & 359140 & Gastrioceras crencellatum \\
\hline $\begin{array}{l}\text { Biddulph, W bank of R. Trent, } 320 \text { yds SW by } \\
\text { W of Cowall }\end{array}$ & 390110 & 355510 & $\begin{array}{l}\text { Cancelloceras cancellatum, Bilinguites } \\
\text { superbilinguis }\end{array}$ \\
\hline LOCALITY & EASTING & $\begin{array}{l}\text { NORTHIN } \\
\text { G }\end{array}$ & AMMONOIDS \\
\hline \multicolumn{4}{|c|}{ Cancelloceras cancellatum Marine Band (G1a1) Continued } \\
\hline Harewood Grange, N side of R. Hipper & 431280 & 368080 & Gastrioceras crencellatum \\
\hline $\begin{array}{l}\text { Walnut Opencast C11 BH, N bank of Carr } \\
\text { Brook, } 1970 \text { yds N86E of Butterley Reservoir }\end{array}$ & 436360 & 360130 & $\begin{array}{l}\text { Gastrioceras cf. crencellatum, G. cf. } \\
\text { rurae, G. sp. }\end{array}$ \\
\hline Calow No $1 \mathrm{BH}$ & 440860 & 370410 & Gastrioceras crencellatum \\
\hline Bothamsall No $5 \mathrm{BH}$ & 466595 & 373440 & Gastrioceras cf. crencellatum \\
\hline Farley's Wood No 2 BH & 470969 & 369997 & $\begin{array}{l}\text { Gastrioceras crencellatum, G. } \\
\text { crencellatum, G. cf. cumbriense, cf. } \\
\text { Agastrioceras carinatum }\end{array}$ \\
\hline Eakring No $1 \mathrm{BH}$ & 467600 & 361330 & Gastrioceras crencellatum \\
\hline Eakring No $3 \mathrm{BH}$ & 467710 & 361450 & Gastrioceras crencellatum \\
\hline Ruelow Wood BH SK04NW/5 & 402050 & 347520 & Gastrioceras crencellatum (2 bands) \\
\hline Rugeley (Trent Valley) BH & 405080 & 319020 & $\begin{array}{l}\text { Gastrioceras crencellatum, with } G . \\
\text { cancellatum \& Reticuloceras } \\
\text { superbilingue in base }\end{array}$ \\
\hline Whittington Heath $\mathrm{BH}$ & 414780 & 308000 & $\begin{array}{l}\text { Gastrioceras cancellatum, Reticuloceras } \\
\text { superbilingue }\end{array}$ \\
\hline Blackfordby No. $1 \mathrm{BH}$ & 432350 & 318270 & ?Gastrioceras cancellatum \\
\hline Sandoz Chemical Co. & 416300 & 434300 & $\begin{array}{l}\text { Gastrioceras crencellatum, with G. rurae } \\
\text { in lower bed \& G. cf. carinatum in upper }\end{array}$ \\
\hline Winksley $\mathrm{BH}$ & 425070 & 471510 & Gastrioceras cancellatum \\
\hline \multicolumn{4}{|l|}{ Cancelloceras cumbriense Marine Band (G1b1) } \\
\hline $\begin{array}{l}\mathrm{N} \text { side of Willow railway cutting - NNE of } \\
\text { Chorley Station }\end{array}$ & 359520 & 419250 & Gastrioceras cumbriense. G. crenulatum \\
\hline Bigrigg - Cumberland & 300100 & 513050 & Gastrioceras cumbriense \\
\hline $\begin{array}{l}\text { Mousegill - 120yds W + 20deg S of } \\
\text { Swinestone House - Westmorland }\end{array}$ & 383680 & 512420 & Gastrioceras cf. cumbriense \\
\hline $\begin{array}{l}\text { Horsforth UD Waterworks BH - 2mls N of } \\
\text { Horsforth SE24SW/7a }\end{array}$ & 423370 & 441160 & Gastrioceras cumbriense \\
\hline River Greta & 361700 & 472230 & $\begin{array}{l}\text { Cancelloceras cf. cumbriense, } \\
\text { Homoceratoides sp. }\end{array}$ \\
\hline Newton Bank BH & 395820 & 395060 & Gastrioceras cumbriense \\
\hline Harrop Brook & 395830 & 378450 & $\begin{array}{l}\text { Gastrioceras cumbriense, G. } \\
\text { crenulatum, Homoceratoides aff. } \\
\text { divaricatus }\end{array}$ \\
\hline Orchard Farm & 402260 & 369030 & Cancelloceras cumbriense \\
\hline Waters Farm BH & 375370 & 467630 & $\begin{array}{l}\text { Cancelloceras cumbriense, } \\
\text { Gastrioceras crenulatum }\end{array}$ \\
\hline Goat Gap Syke & 371630 & 469970 & $\begin{array}{l}\text { Cancelloceras cumbriense, } \\
\text { Gastrioceras crenulatum }\end{array}$ \\
\hline Farnham BH SE35NE/27 & 434690 & 459960 & $\begin{array}{l}\text { Cancelloceras cumbriense, } \\
\text { Gastrioceras crenulatum }\end{array}$ \\
\hline High Lea Farm, Lower Trap & 377200 & 435400 & $\begin{array}{l}\text { Cancelloceras cumbriense, Ca. } \\
\text { crenulatum, Homoceratoides divaricatus }\end{array}$ \\
\hline Monkroyd Beck, NNE of Monkroyd & 393400 & 441400 & Gastrioceras cumbriense \\
\hline North bank of Swinden Water & 390600 & 433000 & Gastrioceras cumbriense \\
\hline Brook east of Combe Hill Cross & 395800 & 438500 & Gastrioceras cumbriense \\
\hline Aire Valley BH 43 SE13NW/23 & 410270 & 439040 & $\begin{array}{l}\text { Cancelloceras cumbriense, Ca. } \\
\text { crenulatum }\end{array}$ \\
\hline Aire Valley BH 29 SE13NE/29 & 415010 & 437880 & Cancelloceras cumbriense \\
\hline Oaks Farm, Yeadon & 424040 & 441200 & $\begin{array}{l}\text { Cancelloceras cumbriense, Ca. } \\
\text { crenulatum }\end{array}$ \\
\hline Middle Moor Clough 600 yards SW of Upper & 397500 & 435900 & Cancelloceras cumbriense, \\
\hline
\end{tabular}




\begin{tabular}{|c|c|c|c|}
\hline Ponden & & & $\begin{array}{l}\text { Gastrioceras crenulatum, } R \text {. } \\
\text { superbilinguis }\end{array}$ \\
\hline Gill Beck 400 yards N14E of Ash House Farm & 414600 & 441800 & $\begin{array}{l}\text { Cancelloceras cumbriense, } \\
\text { Gastrioceras crenulatum }\end{array}$ \\
\hline Yeadon Brick \& Tile Works & 419400 & 440900 & $\begin{array}{l}\text { Cancelloceras cancellatum, } \\
\text { Gastrioceras crenulatum }\end{array}$ \\
\hline Sydney Works BH, Fairweather Green & 413400 & 433300 & $\begin{array}{l}\text { Cancelloceras cumbriense, } \\
\text { Gastrioceras crenulatum }\end{array}$ \\
\hline New Lane Mills Laisterdyke & 419100 & 432700 & $\begin{array}{l}\text { Cancelloceras cancellatum, } \\
\text { Gastrioceras crenulatum }\end{array}$ \\
\hline Great Heads Wood, Roundhay Park & 433600 & 438500 & Gastrioceras cumbriense \\
\hline $\begin{array}{l}\text { Shore Brook } 320 \text { yds SE of Higher House, } 2 \\
\text { miles W of Belmont }\end{array}$ & 364520 & 415300 & $\begin{array}{l}\text { Gastrioceras cumbriense, G. } \\
\text { crenulatum }\end{array}$ \\
\hline LOCALITY & EASTING & $\begin{array}{l}\text { NORTHIN } \\
\text { G }\end{array}$ & AMMONOIDS \\
\hline \multicolumn{4}{|c|}{ Cancelloceras cumbriense Marine Band (G1b1) Continued } \\
\hline Yarrow valley 900 yds W40S of Euxton Hall & 354730 & 417950 & $\begin{array}{l}\text { Gastrioceras cumbriense, G. } \\
\text { crenulatum }\end{array}$ \\
\hline Booth's Farm BH & 354220 & 417310 & Gastrioceras cumbriense \\
\hline Oxspring Borehole, SE of Oxspring SE20SE/6 & 427870 & 401360 & $\begin{array}{l}\text { Gastrioceras cf. crenulatum, G. cf. } \\
\text { cumbriense }\end{array}$ \\
\hline Moss Oil BH & 459980 & 413900 & $\begin{array}{l}\text { Cancelloceras crenulatum, Ca. } \\
\text { cumbriense }\end{array}$ \\
\hline Trumfleet No $1 \mathrm{BH}$ & 460520 & 412640 & $\begin{array}{l}\text { Cancelloceras crenulatum, Ca. } \\
\text { cumbriense }\end{array}$ \\
\hline Askern Oil BH & 456520 & 415020 & Cancelloceras cumbriense \\
\hline $\mathrm{N}$ of Rowarth & 401610 & 389840 & Gastrioceras cumbriense \\
\hline Fernilee No. $1 \mathrm{BH}$ & 401240 & 378230 & $\begin{array}{l}\text { Gastrioceras cumbriense, } G \text {. } \\
\text { crenulatum }\end{array}$ \\
\hline Mather Clough & 397740 & 382250 & $\begin{array}{l}\text { Gastrioceras cumbriense, G. } \\
\text { crenulatum }\end{array}$ \\
\hline Stream, 0.5 miles $\mathrm{W}$ by $\mathrm{S}$ of Handley Fold & 397400 & 380540 & $\begin{array}{l}\text { Gastrioceras cumbriense, G. } \\
\text { crenulatum }\end{array}$ \\
\hline Mill Clough & 400240 & 378070 & Gastrioceras cumbriense \\
\hline Shooter's Clough & 400570 & 374670 & $\begin{array}{l}\text { Gastrioceras cumbriense, } \\
\text { Homoceratoides aff. divaricatus }\end{array}$ \\
\hline Holes Clough & 423830 & 390380 & $\begin{array}{l}\text { Gastrioceras cumbriense, G. } \\
\text { crenulatum, Homoceratoides aff. } \\
\text { divaricatus }\end{array}$ \\
\hline Ughill Brook, 160 yds N7W of Corker Walls & 426100 & 390100 & Gastrioceras cumbriense, G. crenulatum \\
\hline Rod Moor No $3 \mathrm{BH}$ & 426780 & 389160 & Gastrioceras cumbriense, G. crenulatum \\
\hline $\begin{array}{l}\text { Stream } 633 \text { yds N33E of Norfolk Arms, } \\
\text { Ringinglow }\end{array}$ & 429400 & 384200 & Gastrioceras cumbriense, G. crenulatum \\
\hline $\begin{array}{l}\text { Stream } 130 \text { yds } \mathrm{N} \text { of chapel at Longshaw } \\
\text { Lodge }\end{array}$ & 426400 & 380000 & Gastrioceras cumbriense, G. crenulatum \\
\hline Barr Brook, $30 \mathrm{ft}$ below Rough Rock & 427900 & 375000 & Gastrioceras cumbriense, G. crenulatum \\
\hline Smeekley No 3 BH SK27NE/2 & 429690 & 376498 & Gastrioceras cumbriense, G. crenulatum \\
\hline Tickhill No $1 \mathrm{BH}$ & 457730 & 392970 & Gastrioceras cumbriense \\
\hline Warren Dingle & 332270 & 362320 & $\begin{array}{l}\text { Cancelloceras cumbriense, Ca. } \\
\text { crenulatum }\end{array}$ \\
\hline Leeswood Old Hall & 326410 & 361300 & $\begin{array}{l}\text { Cancelloceras cumbriense, Ca. } \\
\text { crenulatum }\end{array}$ \\
\hline $\begin{array}{l}\text { Congleton, E bank of gully, } 560 \text { yds ENE of } \\
\text { Timbersbrook crossroads }\end{array}$ & 389990 & 362860 & $\begin{array}{l}\text { Cancelloceras cf. cumbriense, Ca. } \\
\text { crenulatum }\end{array}$ \\
\hline $\begin{array}{l}\text { Biddulph, W bank of stream, } 640 \text { yds SW by S } \\
\text { of Bridestones }\end{array}$ & 390310 & 361760 & Cancelloceras cf. cumbriense \\
\hline $\begin{array}{l}\text { Biddulph, SE bank of R. Trent, } 390 \text { yds SW of } \\
\text { Cowall }\end{array}$ & 390110 & 355420 & $\begin{array}{l}\text { Cancelloceras cumbriense, Ca. cf. } \\
\text { crenulatum }\end{array}$ \\
\hline Abbey Mills $\mathrm{BH} 4$ & 319490 & 377470 & Gastrioceras cumbriense \\
\hline Harewood Grange, N side of R. Hipper & 431250 & 368110 & Gastrioceras cumbriense \\
\hline 220 yds SE of Lea Hall & 433530 & 357370 & $\begin{array}{l}\text { Gastrioceras cumbriense, G. } \\
\text { crenulatum, Homoceratoides aff. } \\
\text { divaricatus }\end{array}$ \\
\hline Calow No $1 \mathrm{BH}$ & 440860 & 370410 & Gastrioceras cumbriense, G. crenulatum \\
\hline Ruelow Wood BH & 402050 & 347520 & Gastrioceras cumbriense (2 bands) \\
\hline Beelow Hill & 406620 & 345060 & Gastrioceras cumbriense \\
\hline Rugeley (Trent Valley) BH & 405080 & 319020 & Gastrioceras cumbriense \\
\hline Blackfordby No. $1 \mathrm{BH}$ & 432350 & 318270 & Gastrioceras cumbriense \\
\hline
\end{tabular}




\begin{tabular}{|c|c|c|c|}
\hline Sandoz Chemical Co. BH & 416300 & 434300 & $\begin{array}{l}\text { Gastrioceras cumbriense, } \\
\text { Homoceratoides divaricatum; G. sp., G. } \\
\text { carbonarium in upper part }\end{array}$ \\
\hline Asfordby Hydro BH SK72SW 71 & 472520 & 320610 & Gastrioceras cf. crenulatum \\
\hline \multicolumn{4}{|l|}{ Gastrioceras subcrenatum Marine Band (G2a1) } \\
\hline Ballavarish Bh, Shellag north Bh & 246250 & 500700 & Gastrioceras subcrenatum \\
\hline Ridgeway Bh & 389220 & 353810 & Gastrioceras subcrenatum \\
\hline River Greta & 364360 & 472040 & Gastrioceras subcrenatum \\
\hline Stake Clough, NW of Goyt's Moss & 400660 & 372910 & Gastrioceras subcrenatum \\
\hline $\begin{array}{l}400 \text { yds SW of Arnold Hill reservoir, Gee } \\
\text { Cross }\end{array}$ & 395000 & 393000 & Gastrioceras subcrenatum \\
\hline LOCALITY & EASTING & $\begin{array}{l}\text { NORTHIN } \\
\text { G }\end{array}$ & AMMONOIDS \\
\hline \multicolumn{4}{|c|}{ Gastrioceras subcrenatum Marine Band (G2a1) Continued } \\
\hline Bakestonedale $\mathrm{BH}$ & 395940 & 379510 & Gastrioceras sp. \\
\hline Mere Burn & 408860 & 554850 & Gastrioceras subcrenatum \\
\hline $\begin{array}{l}\text { River Little Don, 1km E of Langsett (type } \\
\text { section) }\end{array}$ & 422150 & 400410 & Gastrioceras subcrenatum \\
\hline Harrington No. $19 \mathrm{BH}$ & 299500 & 521000 & Gastrioceras subcrenatum \\
\hline St. Bees No. $4 \mathrm{BH}$ & 295000 & 512700 & Gastrioceras subcrenatum \\
\hline Whitehaven Laundry $\mathrm{BH}$ & 297600 & 516800 & Gastrioceras subcrenatum \\
\hline Waters Farm BH & 375370 & 467630 & Gastrioceras subcrenatum \\
\hline South of Blackwood Head, Wheatley Lane & 383200 & 438200 & $\begin{array}{l}\text { Gastrioceras subcrenatum, } \\
\text { Reticuloceras superbilingue }\end{array}$ \\
\hline $\begin{array}{l}\text { South bank of Colne Water, } 450 \text { yards east of } \\
\text { Carry Bridge }\end{array}$ & 390000 & 439800 & Gastrioceras cf. subcrenatum \\
\hline Horsforth Water Works BH SE24SW/7a & 423370 & 441160 & Gastrioceras subcrenatum \\
\hline Thornton Moor & 405300 & 432600 & Gastrioceras subcrenatum \\
\hline Cottingley Moor Bridge & 411200 & 436200 & Gastrioceras subcrenatum \\
\hline Thackley Tunnel, NW of Apperley Bridge & 418400 & 438700 & Gastrioceras subcrenatum \\
\hline Newlay cutting & 423200 & 436800 & Gastrioceras subcrenatum \\
\hline Top Mill $\mathrm{BH}, 400$ yards NW of Alerton & 411800 & 434400 & Gastrioceras subcrenatum, G. listeri \\
\hline Sydney Works BH, Fairweather Green & 413400 & 433300 & Gastrioceras carbonarium \\
\hline Horsforth UD Waterworks BH - N of Horsforth & 423370 & 441160 & Gastrioceras subcrenatum \\
\hline Union Mills & 418600 & 435600 & Gastrioceras cf. subcrenatum \\
\hline Alston Works BH & 414600 & 433400 & Gastrioceras subcrenatum \\
\hline Britannia Mills $\mathrm{BH}$ & 416400 & 432500 & Gastrioceras subcrenatum \\
\hline Sandoz Chemical Co. BH & 416300 & 434300 & Gastrioceras carbonarium \\
\hline $\begin{array}{l}\text { Globe Mills BH, Leeds, } 400 \text { yards S of City } \\
\text { station SE23SE/7 }\end{array}$ & 4297990 & 4327870 & $\begin{array}{l}\text { Gastrioceras spp., G. retrorsum, } R . \\
\text { reticuloceras }\end{array}$ \\
\hline $\begin{array}{l}\text { North bank R. Darwen, } 120 \text { yds SE of Old } \\
\text { Hall, Feniscowles }\end{array}$ & 363780 & 425720 & Gastrioceras subcrenatum \\
\hline $\begin{array}{l}\text { Stepback Brook, W of Darwen Hill, } 1300 \text { yds } \\
\text { S42E of the inn at Ryal Fold }\end{array}$ & 367310 & 420650 & Gastrioceras subcrenatum \\
\hline 560 yds NNW of St Stephen's Church, Chapel & 365760 & 424000 & Gastrioceras subcrenatum \\
\hline Howe Brook, S of Brook House & 352280 & 413980 & Gastrioceras subcrenatum, G. sp. \\
\hline Heskin $\mathrm{BH}$ & 353890 & 414500 & Gastrioceras subcrenatum, G. sp. \\
\hline Oughtibridge, 200 yds W of station & 431000 & 393500 & Gastrioceras subcrenatum \\
\hline Moss Oil BH SE51SE/19 & 459980 & 413900 & Gastrioceras subcrenatum \\
\hline Fernilee No. $2 \mathrm{BH}$ & 401190 & 378630 & Gastrioceras subcrenatum \\
\hline E of Fernilee & 401910 & 378510 & Gastrioceras subcrenatum \\
\hline Shaw Farm BH, 0.5 miles NW of Eaves Knoll & 399050 & 386610 & $\begin{array}{l}\text { Gastrioceras subcrenatum, } \\
\text { Homoceratoides sp. G. sp. }\end{array}$ \\
\hline Knowle Wood & 398160 & 388660 & Gastrioceras subcrenatum, G. sp. \\
\hline S of Sugworth Road, near Moscar & 424000 & 389500 & $\begin{array}{l}\text { Gastrioceras subcrenatum, G. sp., G. } \\
\text { sp. nov. }\end{array}$ \\
\hline Smeekley No 3 BH SK27NE/2 & 429690 & 376498 & Gastrioceras subcrenatum \\
\hline Tickhill No 1 BH & 457730 & 392970 & $\begin{array}{l}\text { Gastrioceras subcrenatum, } \\
\text { Homoceratoides aff. divaricatus }\end{array}$ \\
\hline Ranskill No $1 \mathrm{BH}$ & 464230 & 388140 & Gastrioceras subcrenatum \\
\hline Oakenholt Paper Mill BH & 326280 & 375120 & $\begin{array}{l}\text { Gastrioceras subcrenatum, G. cf. } \\
\text { rertrorsum }\end{array}$ \\
\hline Alders Farm BH & 389540 & 362080 & Gastrioceras subcrenatum \\
\hline $\begin{array}{l}\text { R. Hipper, } 360 \text { yds up from Harewood Grange } \\
\text { bridge }\end{array}$ & 431110 & 368350 & $\begin{array}{l}\text { Gastrioceras subcrenatum, G. sp. nov., } \\
\text { G. sp., Homoceratoides sp. }\end{array}$ \\
\hline 760 yds N33W of Stonehay Farm & 432800 & 368080 & Gastrioceras subcrenatum \\
\hline Opencast workings SW of Alton & 436070 & 364200 & Gastrioceras subcrenatum \\
\hline $\begin{array}{l}\text { Clattercotes Wood, } 400 \text { yds N15E of } \\
\text { Whitecarr }\end{array}$ & 436120 & 360140 & $\begin{array}{l}\text { Gastrioceras subcrenatum, G. sp. nov., } \\
\text { Homoceratoides sp. }\end{array}$ \\
\hline
\end{tabular}




\begin{tabular}{|c|c|c|c|}
\hline Egmanton No $62 \mathrm{BH}$ & 474440 & 367770 & Gastrioceras subcrenatum \\
\hline Ruelow Wood BH & 402050 & 347520 & Gastrioceras subcrenatum \\
\hline Wetley Rocks & 396640 & 349440 & Gastrioceras subcrenatum \\
\hline Consall New Lock & 400420 & 348360 & Gastrioceras subcrenatum \\
\hline Newhouse Wood, Ipstones & 401770 & 348850 & Gastrioceras subcrenatum \\
\hline Crowtrees No. 8 BH SK04NW/19 & 404980 & 345590 & Gastrioceras subcrenatum \\
\hline $\begin{array}{l}\text { Rugeley (Trent Valley) BH } 100 \text { yds ESE of } \\
\text { Railway Inn, Rugeley }\end{array}$ & 405080 & 319020 & Gastrioceras subcrenatum \\
\hline Osbaston Hollow $\mathrm{BH}$ & 441660 & 306350 & Gastrioceras \\
\hline Park Brook BH, Horsley & 438300 & 343850 & Gastrioceras subcrenatum \\
\hline Nether Heage $\mathrm{BH}$ & 435990 & 351190 & Gastrioceras subcrenatum \\
\hline Beechdale Rd (Robins Wood) BH & 453610 & 341130 & Gastrioceras subcrenatum \\
\hline LOCALITY & EASTING & $\begin{array}{l}\text { NORTHIN } \\
\text { G }\end{array}$ & AMMONOIDS \\
\hline \multicolumn{4}{|c|}{ Gastrioceras subcrenatum Marine Band (G2a1) Continued } \\
\hline Wilds Bridge BH SK63SE/30 & 467380 & 332480 & Gastrioceras subcrenatum \\
\hline Blackfordby No. $1 \mathrm{BH}$ & 432350 & 318270 & Gastrioceras subcrenatum \\
\hline Road cut & 437640 & 324860 & Gastrioceras subcrenatum, G. sp \\
\hline Worthington BH SK24SW/204 & 440450 & 321040 & $\begin{array}{l}\text { Gastrioceras sp., Gastrioceras } \\
\text { subcrenatum }\end{array}$ \\
\hline \multicolumn{4}{|l|}{ Honley Marine Band } \\
\hline Ridgeway Bh SJ85SE/14 & 389220 & 353810 & Gastrioceras sp. \\
\hline Charnock Old Hall BH & 354730 & 416560 & Gastrioceras sp. \\
\hline Cheshire Brook & 389030 & 361430 & Gastrioceras sp. \\
\hline \multicolumn{4}{|l|}{ Listeri Marine Band } \\
\hline Ridgeway Bh SJ85SE/14 & 389220 & 353810 & Gastrioceras listeri \\
\hline Robin's Clough near Knar & 400420 & 367630 & Gastrioceras listeri \\
\hline Waters Farm BH & 375370 & 467630 & Gastrioceras listeri , G. circumnodosum \\
\hline Valley Mills BH & 386700 & 437200 & Gastrioceras listeri \\
\hline Cockden Bridge $\mathrm{BH}$ & 387600 & 434400 & Gastrioceras listeri \\
\hline $\begin{array}{l}\text { Globe Mills BH, Leeds, } 400 \text { yards S of City } \\
\text { station SE23SE/7 }\end{array}$ & 429799 & 432787 & Gastrioceras listeri \\
\hline $\begin{array}{l}\text { Stepback Brook, } 900 \text { yds S35W of Darwen } \\
\text { Tower }\end{array}$ & 367410 & 420920 & Gastrioceras listeri \\
\hline Tan House Farm BH & 355420 & 416920 & Gastrioceras listeri \\
\hline Heskin $\mathrm{BH}$ & 353010 & 401360 & Gastrioceras listeri \\
\hline $\begin{array}{l}\text { Oxspring Borehole,SE of Oxspring } \\
\text { Yorks SE20SE/6 }\end{array}$ & 427870 & 401360 & Gastrioceras listeri \\
\hline Moss Oil BH SE51SE/19 & 459980 & 413900 & Gastrioceras listeri \\
\hline Ringstone Clough & 400080 & 382210 & Gastrioceras listeri \\
\hline Furness Vale Colliery & 400380 & 383390 & $\begin{array}{l}\text { Gastrioceras listeri, Homoceratoides aff. } \\
\text { divaricatus }\end{array}$ \\
\hline Pingot Clough & 401640 & 385320 & Gastrioceras listeri \\
\hline Stirrup, west of Chisworth & 398350 & 391870 & Gastrioceras listeri \\
\hline Chew & 399400 & 392030 & Gastrioceras listeri \\
\hline Smeekley No 3 BH SK27NE/2 & 429690 & 376498 & Gastrioceras listeri \\
\hline Connah's Quay, trial pit & 328170 & 369160 & Gastrioceras listeri \\
\hline Biddulph Grange & 389210 & 359610 & Gastrioceras circumnodosum \\
\hline Cheshire Brook & 388970 & 361330 & Gastrioceras circumnodosum, G. listeri \\
\hline $\begin{array}{l}\text { Clattercotes Wood, } 480 \text { yds N53E of } \\
\text { Whitecarr }\end{array}$ & 436380 & 360050 & Gastrioceras listeri \\
\hline Key Wood BH SK04NW/1 & 403910 & 345360 & Gastrioceras listeri \\
\hline Out Wood, Consall valley & 398050 & 347810 & Gastrioceras listeri \\
\hline SE of Ipstones & 402980 & 349000 & Gastrioceras circumnodosum \\
\hline Whittington Heath $\mathrm{BH}$ & 414780 & 308000 & Gastrioceras cf. listeri \\
\hline Ellistown Colliery $\mathrm{BH}$ & 443900 & 310560 & Gastrioceras listeri \\
\hline Wilds Bridge $\mathrm{BH}$ SK63SE/30 & 467380 & 332480 & Gastrioceras listeri \\
\hline Marriott Wood Brickpit & 429800 & 380300 & Gastrioceras listeri \\
\hline Little Stubbin Opencast, Stubbinedge & 436300 & 361900 & $\begin{array}{l}\text { Gastrioceras listeri, G. coronatum, G. } \\
\text { retrorsum }\end{array}$ \\
\hline Sandoz Chemical Co & 416300 & 434300 & Gastrioceras listeri \\
\hline \multicolumn{4}{|l|}{ Amaliae Marine Band } \\
\hline $\begin{array}{l}\text { Disused quarry, } 720 \text { yds E14S of Charnock } \\
\text { Green }\end{array}$ & 355980 & 416640 & Gastrioceras cf. amaliae \\
\hline Crook Fold BH & 354700 & 415870 & Gastrioceras cf. amaliae \\
\hline \multicolumn{4}{|l|}{ Vanderbeckei Marine Band } \\
\hline $\begin{array}{l}\text { Wiggins Teape No } 2 \text { BH, Withnell Fold } \\
\text { Chorley }\end{array}$ & 361460 & 423440 & Anthracoceras cf. vanderbeckei \\
\hline
\end{tabular}




\begin{tabular}{|c|c|c|c|}
\hline Bankfield Mills BH - Mold Green - SE11NE/11 & 414660 & 416270 & Anthracoceras aff. vanderbeckei \\
\hline Bowsey Wood BH SJ74NE/9 & 376950 & 346430 & Anthracoceras vanderbeckei \\
\hline Railway cutting, 1615 yds $\mathrm{N}$ of Holy Cross & & & \\
\hline Church, Morton (Clay Cross type locality) & 440730 & 361600 & Anthracoceras cf. vanderbeckei \\
\hline Scaftworth $\mathrm{BH}$ & 467610 & 391670 & Anthracoceras vanderbeckei \\
\hline Disused railway cutting, Duckmanton & 442370 & 370400 & Anthracoceras vanderbeckei \\
\hline Manton Colliery No 7 UG BH & 463786 & 376334 & Anthracoceras vanderbeckei \\
\hline Carbank BH & 463969 & 355793 & Anthracoceras vanderbeckei \\
\hline Haughton Hall BH & 468595 & 373305 & Anthracoceras vanderbeckei \\
\hline Clipstone Colliery No. $1 \mathrm{BH}$ & 459530 & 363290 & Anthracoceras vanderbeckei \\
\hline Kirton $\mathrm{BH}$ & 469880 & 369130 & Anthracoceras vanderbeckei \\
\hline Kneesall BH & 471353 & 364380 & Anthracoceras vanderbeckei \\
\hline Mansfield Colliery $\mathrm{BH}$ & 457020 & 361450 & Anthracoceras vanderbeckei \\
\hline Ompton $\mathrm{BH}$ & 469000 & 366100 & Anthracoceras vanderbeckei \\
\hline LOCALITY & EASTING & $\begin{array}{l}\text { NORTHIN } \\
\text { G }\end{array}$ & AMMONOIDS \\
\hline \multicolumn{4}{|l|}{ Vanderbeckei Marine Band Continued } \\
\hline Foxfield No8 BH SJ94SE/8 & 398880 & 343220 & Anthracoceras vanderbeckei \\
\hline Manchester Woods BH SK44SW/3 & 441600 & 344170 & Anthracoceras vanderbeckei \\
\hline Digby Clay Pit & 448600 & 345000 & Anthracoceras vanderbeckei \\
\hline Jockey House BH SK67NE/18 & 468971 & 376839 & Anthracoceras vanderbeckei \\
\hline \multicolumn{4}{|l|}{ Aegiranum Marine Band } \\
\hline Wentbridge No. 2 BH SE41NE/18 & 447560 & 417570 & Donetzoceras aegiranum \\
\hline Bowsey Wood BH SJ74NE/9 & 376950 & 346430 & Donetzoceras aegiranum \\
\hline Nettlebank Colliery & 388500 & 350300 & Donetzoceras aegiranum \\
\hline Pow Gill, 130 yards $N$ of bridge at Powbank & 325090 & 544320 & $\begin{array}{l}\text { Donetzoceras aegiranum, } \\
\text { Anthracoceras hindi }\end{array}$ \\
\hline Stairfoot Brickworks, 3km ESE of Barnsley & 438030 & 404980 & Donetzoceras aegiranum \\
\hline $\begin{array}{l}\text { Manvers Main Brickworks, } 1650 \text { yds E6S of } \\
\text { Bolton upon Dearne church }\end{array}$ & 445300 & 400980 & Gastrioceras sp. \\
\hline Doles Lane $\mathrm{BH}$ & 453594 & 3774910 & Homoceratoides politus \\
\hline Whitwell Rectory & 452480 & 376670 & Homoceratoides? \\
\hline Elmton Green $\mathrm{BH}$ & 450560 & 373170 & Gastrioceras cf. depressum \\
\hline $\begin{array}{l}\text { Red Hill BH, } 2140 \text { yds W of St James' church } \\
\text { Longdon SK01SE/9 }\end{array}$ & 406230 & 314110 & Homoceratoides politus \\
\hline Albion Clay Pit, 300 yds SSE Dordon church & 426300 & 300100 & Gastrioceras depressum \\
\hline $\begin{array}{l}\text { Robinson \& Dowler's Pit, } 300 \text { yds SSE of } \\
\text { Dordon church }\end{array}$ & 429600 & 316100 & Anthracoceras cf aegiranum-hindi \\
\hline Donington Pit, 250 yds 106 of Swainspark & 429900 & 317100 & Anthracoceras cf aegiranum-hindi \\
\hline Caldwell No. $1 \mathrm{BH}, 250$ yds 106 of Swainspark & 425990 & 317340 & Gastrioceras sp. \\
\hline Eymore Farm railway cutting, Upper Arley & 376900 & 279000 & Donetzoceras aegiranum \\
\hline \multicolumn{4}{|l|}{ Shafton Marine Band } \\
\hline Maltby Main Colliery No 2 shaft & 455120 & 392460 & Anthracoceras hindi \\
\hline \multicolumn{4}{|l|}{ Cambriense Marine Band } \\
\hline Wentbridge No. 2 BH SE41NE/18 & 447560 & 417570 & Donetzoceras cambriense \\
\hline
\end{tabular}




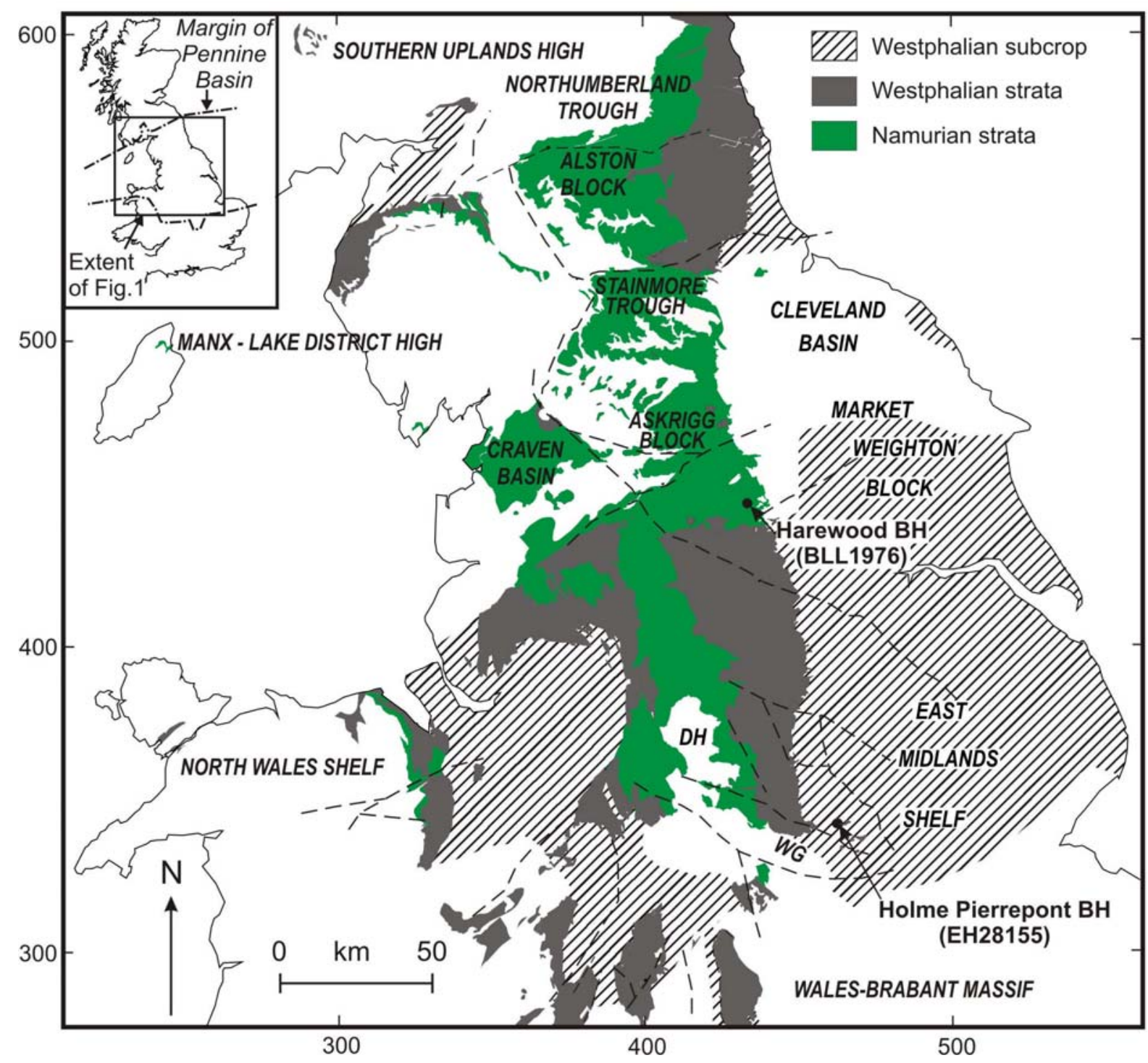

Fig. 1. Map showing the approximate extent of Namurian and Westphalian strata at crop, the subcrop of Westphalian strata and the main pre-Namurian structural features of the Pennine Basin, derived from Waters et al. (2011). The location of the Harewood and Holme Pierrepont boreholes, from which new dates have been acquired during this study, are shown. DH- Derbyshire High, WG- Widmerpool Gulf. 
Fig. 2. U-Pb data for samples BLL1976 and EH28155. A, conventional U-Pb concordia plot of zircons analysed from samples BLL1976 and EH28155. The grey band reflects the uncertainty in the ${ }^{238} \mathrm{U}$ and ${ }^{235} \mathrm{U}$ decay constants (Jaffey et al. 1971). B, plot of ${ }^{238} \mathrm{U} /{ }^{206} \mathrm{~Pb}$ dates for single zircon crystals analyses (same data as in Figure 2a). Dashed ellipses/bars represent analyses of zircon that are considered to be xenocrysts and/or inherited crystals that are disregarded in calculation of final date, whereas as undashed ellipses/bars represent the analyses used for calculation of the weighted mean final date (see text for discussion). Data point error ellipses/bars are $2 \sigma$.
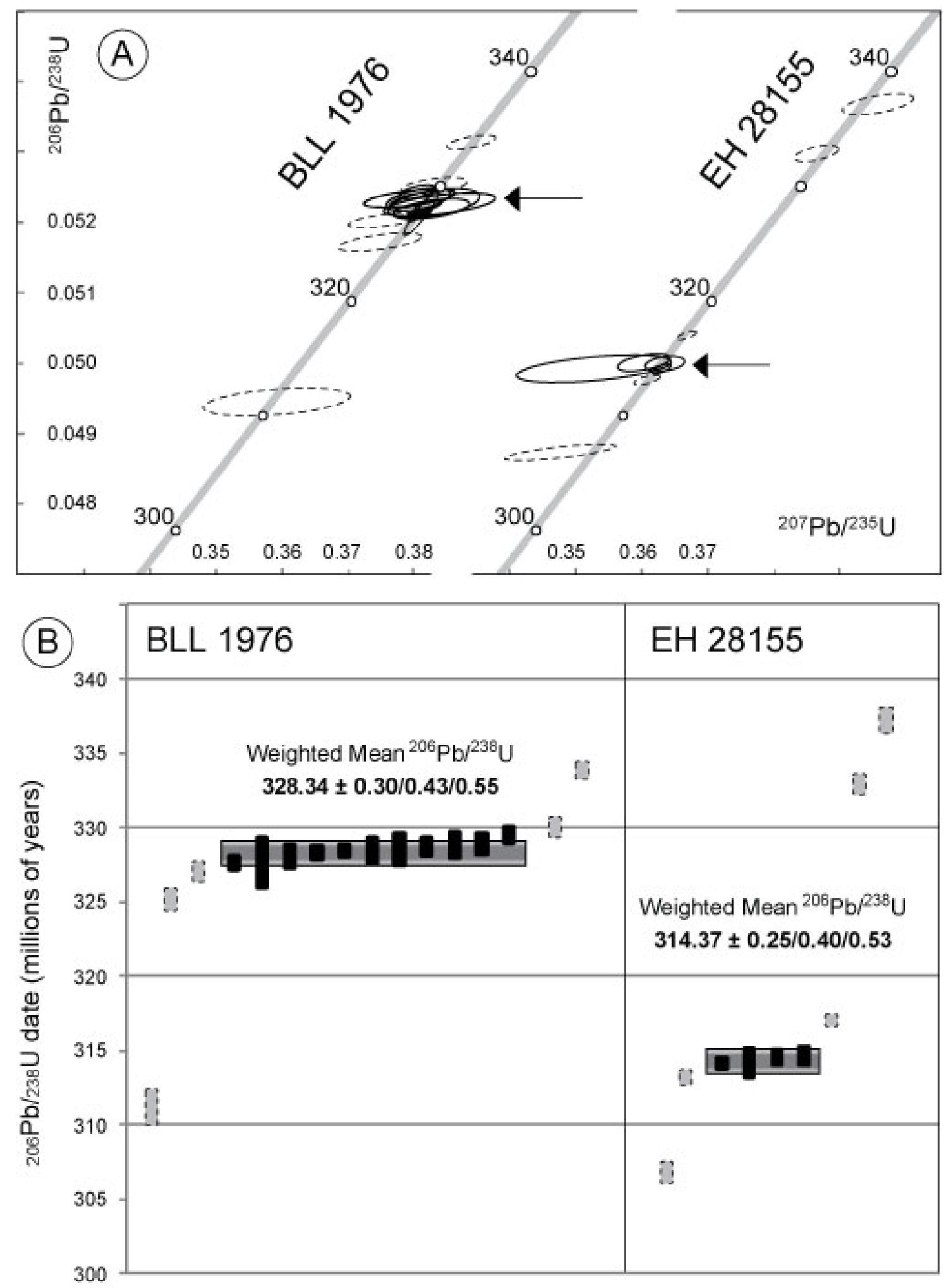


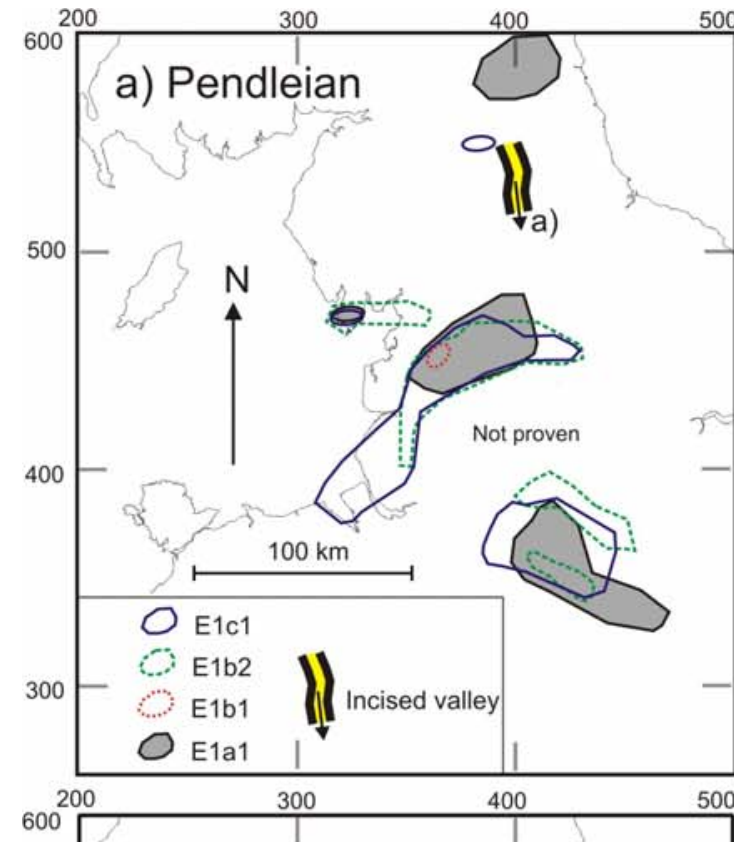

c) Mid to Late Arnsbergian
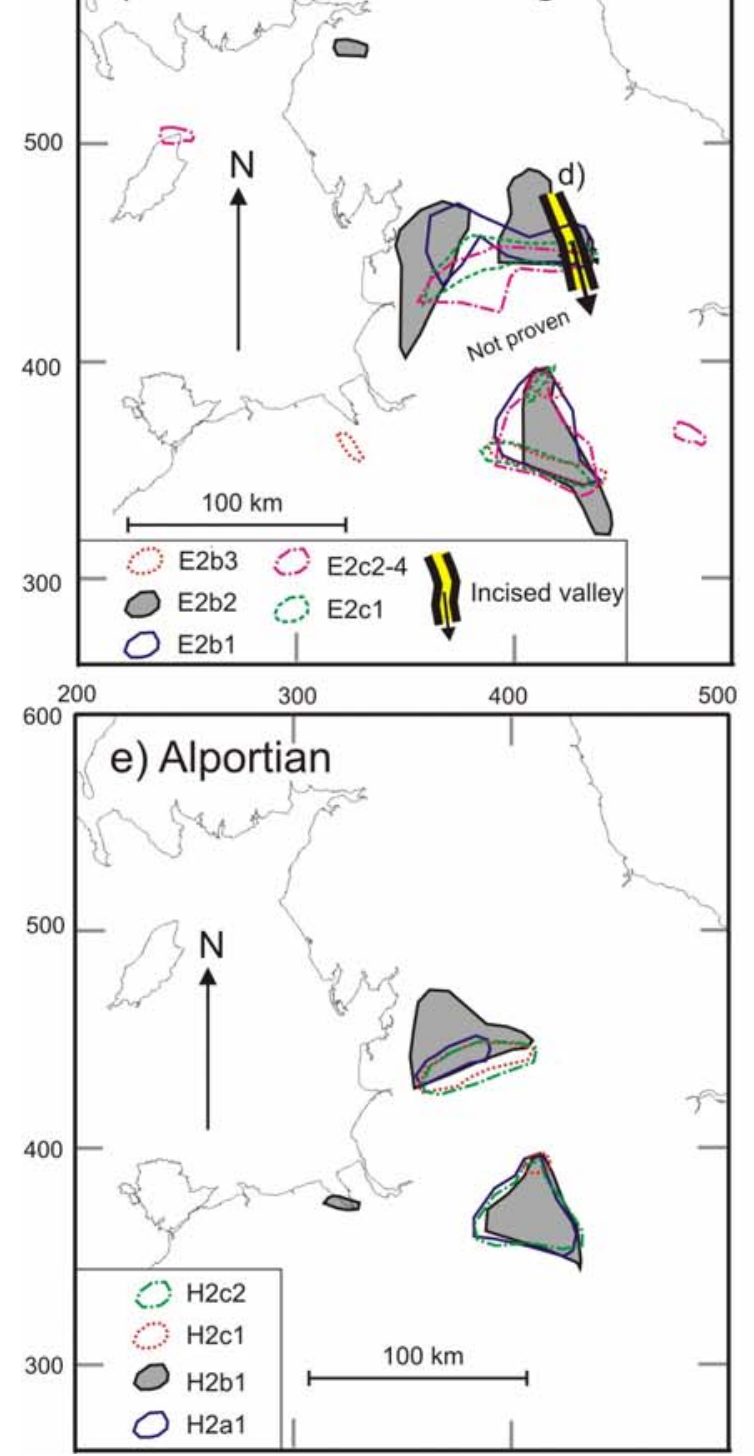

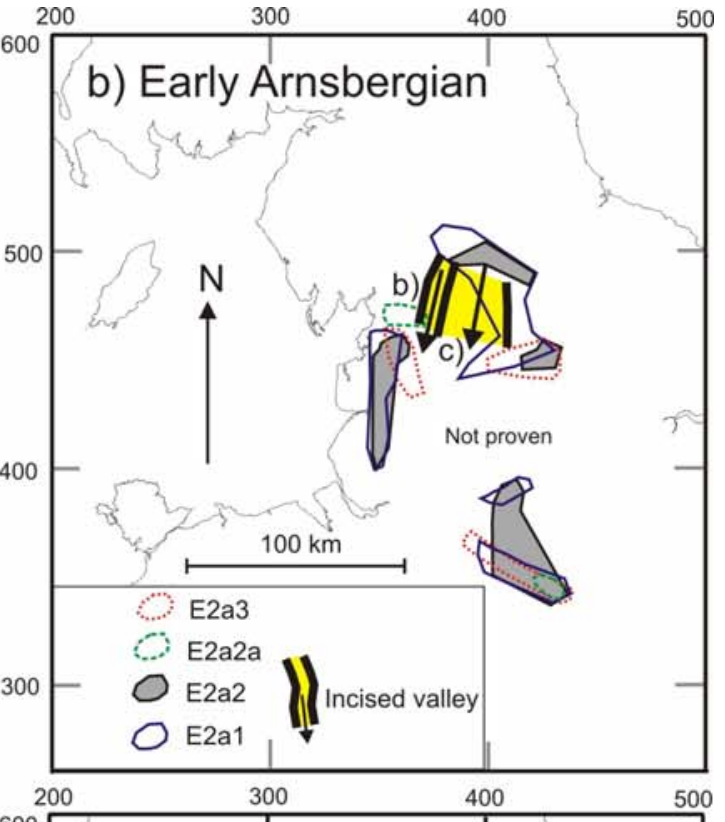

d) Chokierian
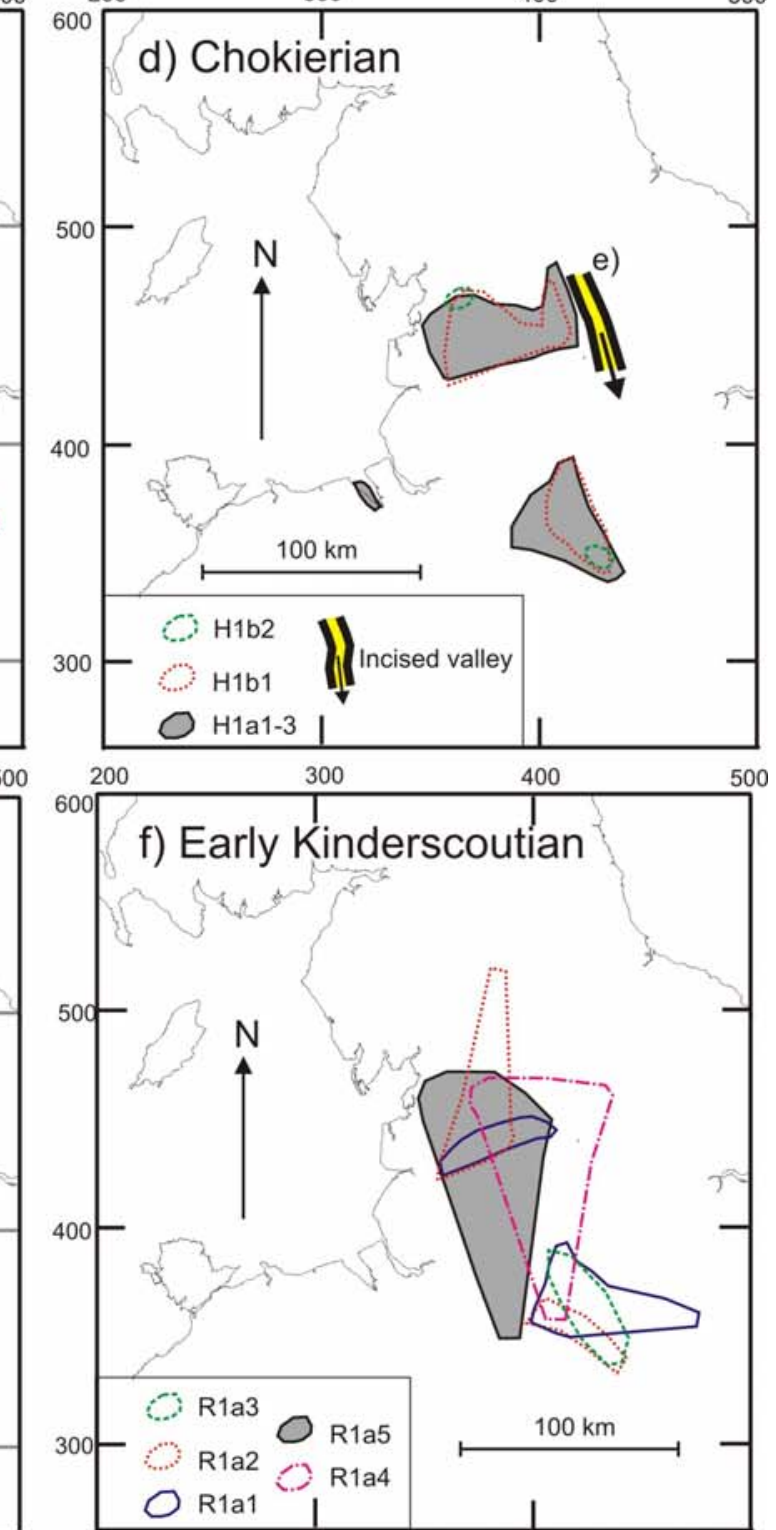

Fig. 3. Distribution of ammonoid acme facies in early Namurian marine bands: a) Pendleian; b) early Arnsbergian; c) mid to late Arnsbergian; d) Chokierian; e) Alportian; f) early Kinderscoutian. Grey tone denotes marine band with maximum areal extent for each interval. Key for Incised Valleys, as for Figure 5. 

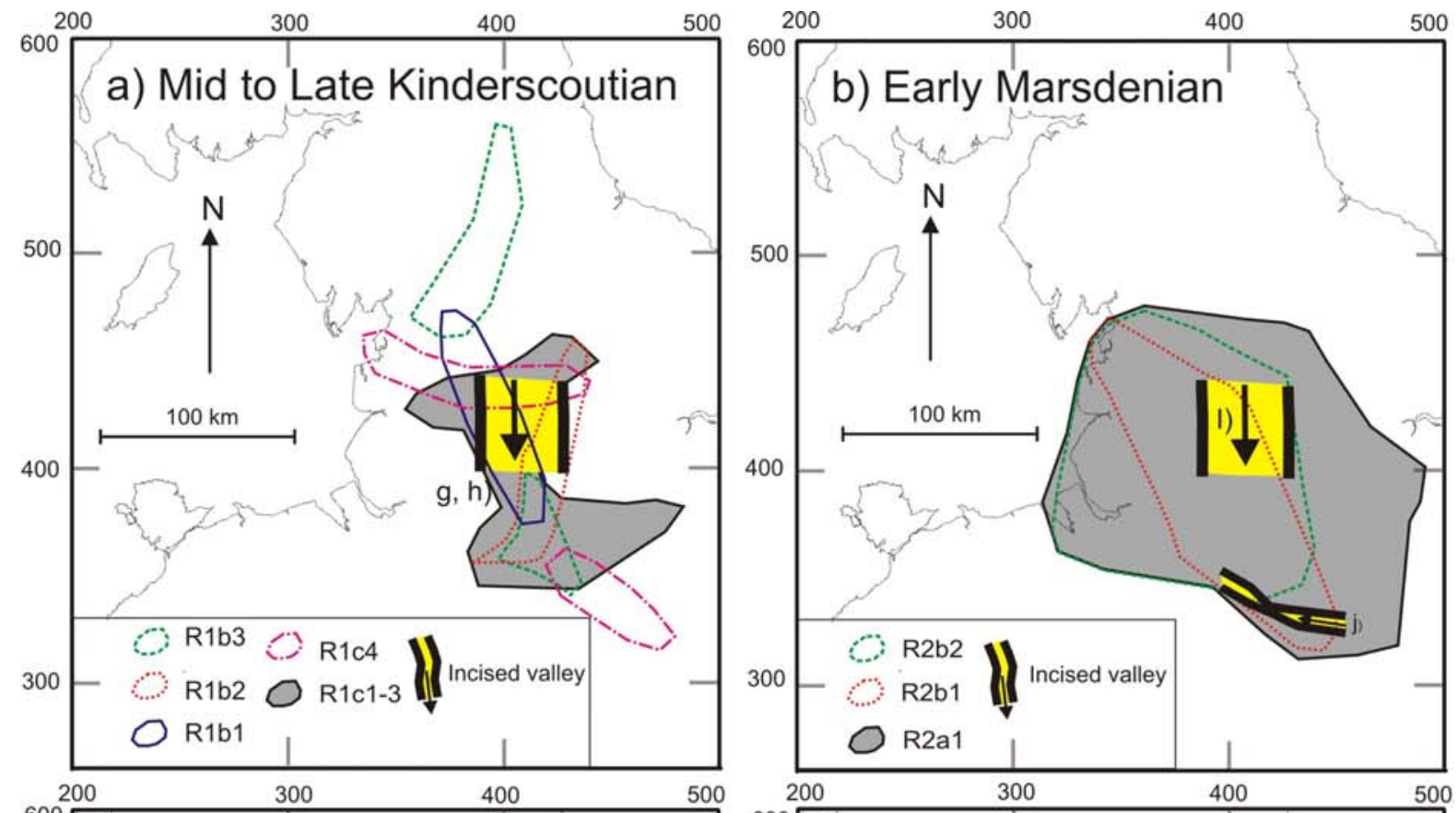

c) Late Marsdenian
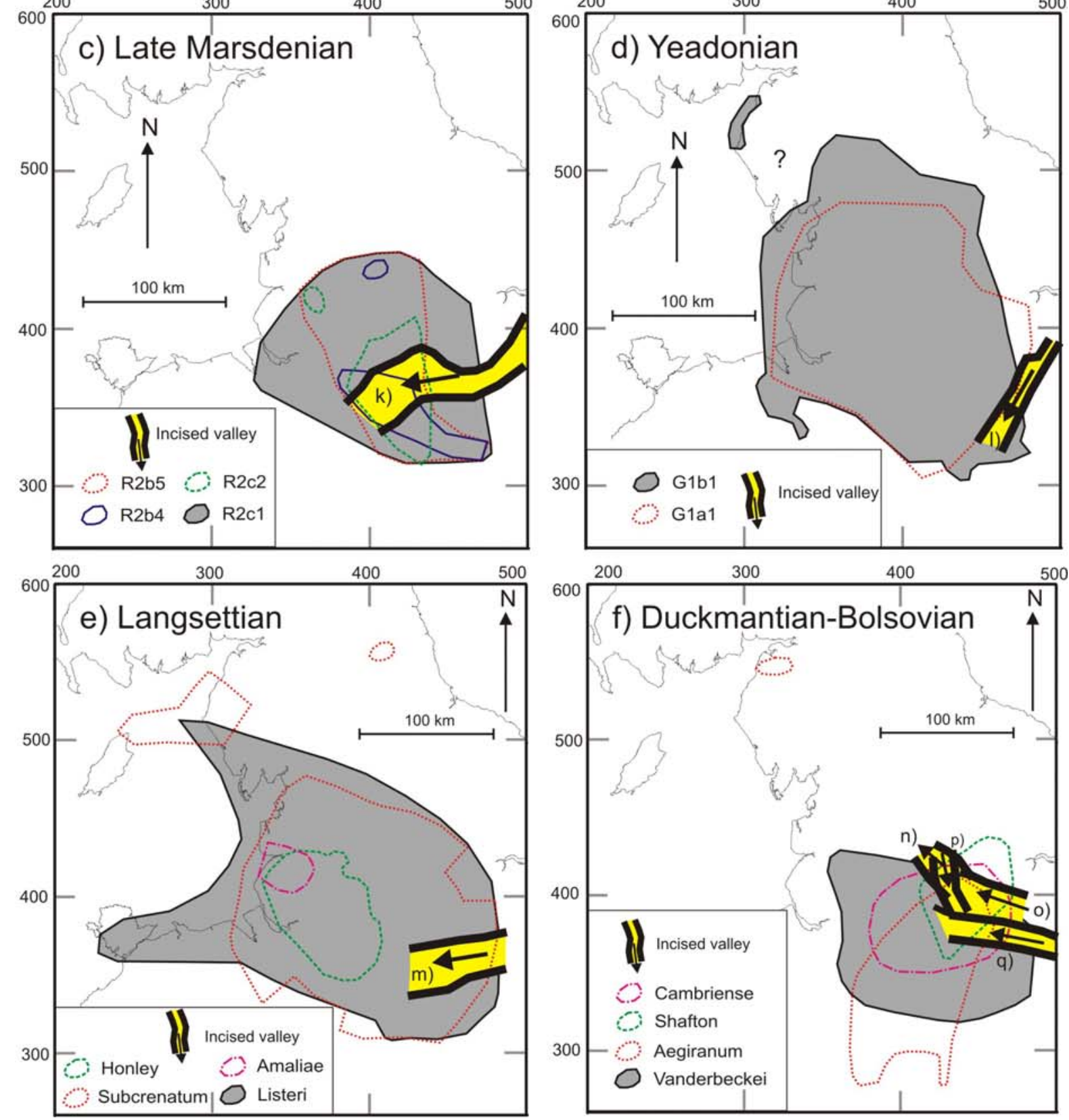
Fig. 4. Distribution of ammonoid acme facies in late Namurian-Westphalian marine bands: a) mid to late Kinderscoutian; b) early Marsdenian; c) late Marsdenian; d) Yeadonian- $\mathrm{G}_{1 \mathrm{~b}} 1$ modified from Wignall (1987); e) Langsettian and f) Duckmantian-Bolsovian, in part based upon Calver (1968, 1969). Grey tone denotes marine band with maximum areal extent for each interval. Key for Incised Valleys, as for Figure 5. 


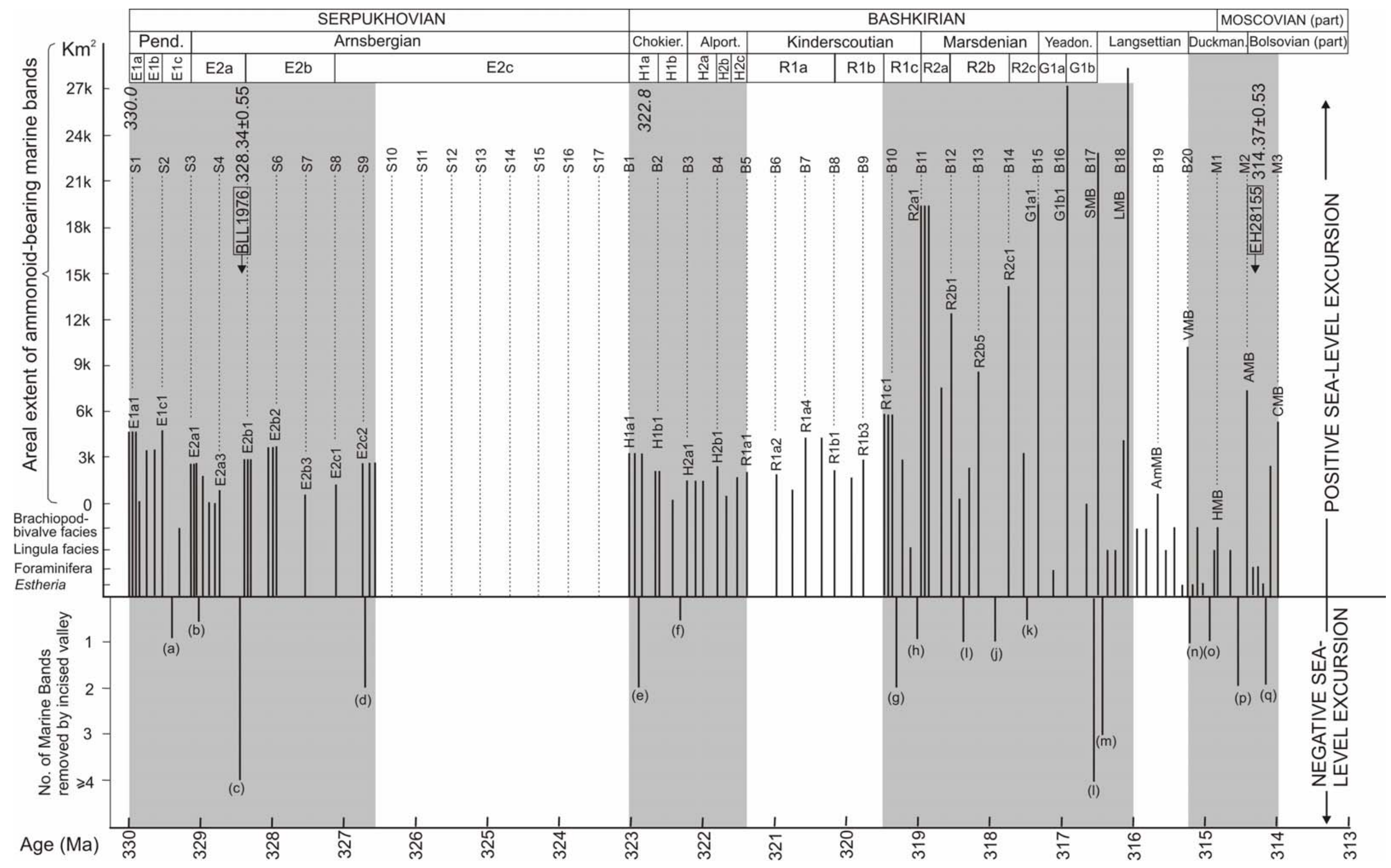


Fig. 5. Magnitude and duration of sea-level oscillations. Sea-level maxima are estimated through the determination of maximum areal extent of acme ammonoid facies. Abbreviations for Westphalian marine bands: SMB Subcrenatum Marine Band; LMB Listeri Marine Band; AmMB Amaliae Marine Band; VMB Vanderbeckei Marine Band; HMB Haughton Marine Band; AMB Aegiranum Marine Band; CMB Cambriense Marine Band. For marine bands lacking ammonoid fauna the magnitude of sea-level is determined through the acme marine fauna, ranging from Estheria to brachiopod-bivalve facies. Sea-level minima are determined through the presence of incised valleys, with the magnitude recorded by the number of underlying marine bands removed beneath the sequence boundary. Sources for incised valleys are as follows: a) Rogerley Channel (Dunham 1990); b) Upper Howgate Edge channel (Martinsen et al. 1995); c) Red Scar Grit (Brandon et al. 1995); d) Lower Follifoot Grit (Martinsen 1993); e) Intra-H 1a $_{1}$ unconformity (Owens et al. 1990); f) Upper Follifoot Grit (Martinsen 1993); g) Todmorden Grit/Kinderscout Grit (Hampson 1997); h) Upper Kinderscout Grit (Hampson 1997); i) Midgley Grit (Brettle 2001); j) Ashover Grit/Roaches Grit (Jones \& Chisholm 1997; Church \& Gawthorpe 1994); k) Chatsworth Grit (Waters et al. 2008); l) Rough Rock (Church \& Gawthorpe 1994); m) Crawshaw Sandstone (Hampson et al. 1997); n) Thornhill Rock (Lake 1999); o) Woolley Edge Rock (Aitken et al. 1999); p) Oaks Rock (Lake 1999); q) Mexborough Rock (Aitken et al. 1999). Radiometric dates are from this study and estimated ages of stage boundaries are from Davydov et al. (2010), with an imposed 400 ka long-duration eccentricity oscillation numbered sequentially for each international stage: S Serpukhovian; B Bashkirian; M Moscovian. The proposed four main glaciations are highlighted as grey bands. 
Table 1. Comparison of Carboniferous chronological ages from selected published literature. Picks are at base of Regional Stage or Substage unless stated otherwise. Hess \& Lippolt (1986) ${ }^{1}$ and Berger et al. (1997) ${ }^{2}$ provide ${ }^{40} \mathrm{Ar} /{ }^{39} \mathrm{Ar}$ plateau ages (Ma $\pm 1 \sigma$ ), with the exception of the early Arnsbergian age which is Ma $\pm 2 \sigma$ : recalibrated ages appear in italics, as quoted in Davydov et al. (2004); Kryza et al. (2010) ${ }^{3}$, Riley et al. $(1995)^{4}$ and Claoué-Long et al. (1995) ${ }^{5}$ provide SHRIMP (Ma $\pm 2 \sigma$ ) ages; Trapp \& Kaufmann (2002) ${ }^{6}$, Gastaldo et al. (2009) ${ }^{7}$ and Davydov et al. (2010) ${ }^{8}$ provide U-Pb TIMS ( $\left.\mathrm{Ma} \pm 2 \sigma\right)$ ages. Stippled lines denote correlation of regional substage boundaries.

\begin{tabular}{|c|c|c|c|c|c|c|c|c|}
\hline $\begin{array}{c}{ }^{40} \mathrm{Ar} /{ }^{39} \mathrm{Ar} \\
\text { plateau ages }\end{array}$ & U-Pb SHRIMP & $\begin{array}{l}\text { Davydov et } \\
\text { al. (2004) }\end{array}$ & $\begin{array}{l}\text { Ogg et al. } \\
\text { (2008) }\end{array}$ & U-Pb TIMS & This study & $\begin{array}{l}\text { International } \\
\text { Stage }\end{array}$ & $\begin{array}{l}\text { Regional } \\
\text { Substage }\end{array}$ & Regional Stage \\
\hline $302.7 \pm 0.5$ (late) $^{(1)}$ & & $306.5 \pm 1.0$ & $307.2 \pm 1.0$ & $307.26 \pm 0.11$ (early) $^{(8)}$ & & Kasimovian & Cantabrian & Early Stephanian \\
\hline $\begin{array}{l}308.0 \pm 1.8(\mathrm{mid})^{(2)} \\
(310.26 \pm 1.8)\end{array}$ & & & & & & \multirow[b]{2}{*}{ Moscovian } & Asturian & \multirow{4}{*}{ Westphalian } \\
\hline $\begin{array}{l}309.0 \pm 3.7 \text { (late) }^{(1)} \\
309.7 \pm 2.0 \text { (mid) }^{(2)} \\
(312.0 \pm 2.0) \\
310.0 \pm 1.0 \\
(313.0 \pm 1.0)\end{array}$ & $311.0 \pm 3.4^{(5)}$ & $311.7 \pm 1.1$ & $311.7 \pm 1.1$ & $314.40 \pm 0.06$ (early) $^{(8)}$ & $314.37 \pm 0.53$ & & Bolsovian & \\
\hline \multirow[t]{7}{*}{$310.7 \pm 1.3$ (late) $^{(1)}$} & & & & & & \multirow{7}{*}{ Bashkirian } & Duckmantian & \\
\hline & & & & & & & Langsettian & \\
\hline & & & & & & & Yeadonian & \multirow{7}{*}{ Namurian } \\
\hline & & & & & & & Marsdenian & \\
\hline & & & & & & & Kinderscoutian & \\
\hline & & & & & & & Alportian & \\
\hline & & $318.1 \pm 1.3$ & $318.1 \pm 1.3$ & & & & Chokierian & \\
\hline \multirow{4}{*}{$\begin{array}{l}319.9 \pm 1.6(\mathrm{mid}) \\
(322.3 \pm 1.7) \\
324.8 \pm 1.2(\text { early })^{(1)} \\
(327.0 \pm 2.2)\end{array}$} & $\begin{array}{l}314.4 \pm 4.6(\mathrm{mid}){ }^{(4)} \\
314.5 \pm 4.6 \text { (early })^{(4)}\end{array}$ & & & & $328.34 \pm 0.55$ & \multirow[t]{2}{*}{ Serpukhovian } & Arnsbergian & \\
\hline & & $326.4 \pm 1.6$ & $328.3 \pm 1.6$ & $\begin{array}{l}328.01 \pm 0.36 \text { (late) }^{(7)} \\
328.14 \pm 0.11 \text { (early-mid) }^{(8)} \\
328.84 \pm 0.38 \text { (early) }^{(7)}\end{array}$ & & & Pendleian & \\
\hline & & & & & & \multirow[t]{2}{*}{ Late Visean } & Brigantian & \multirow[t]{2}{*}{ Late Visean } \\
\hline & $334 \pm 4^{(3)}$ & & & $326.8 \pm 0.98{\text { (late })^{(6)}}^{(6)}$ & & & Asbian & \\
\hline
\end{tabular}




\begin{tabular}{|c|c|c|c|c|c|c|c|}
\hline \multirow{2}{*}{$\begin{array}{l}\text { Regional } \\
\text { Substages }\end{array}$} & \multicolumn{3}{|c|}{ ZONES } & \multicolumn{3}{|c|}{ WESTERN EUROPEAN MARINE BANDS } & \multirow{2}{*}{$\begin{array}{l}\text { 'Meso- } \\
\text { thems' }\end{array}$} \\
\hline & Index & Ammonoid & Index & Diagnostic ammonoid & Former name & Associated ammonoids & \\
\hline \multicolumn{7}{|c|}{ BASHKIRIAN STAGE (NAMURIAN REGIONAL STAGE) } & \multirow{5}{*}{ N11 } \\
\hline \multirow{4}{*}{ 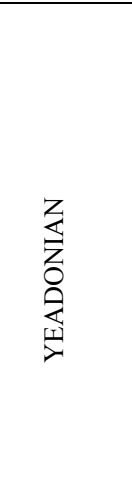 } & \multirow[b]{2}{*}{ G1b } & & & Anthracoceras & & None, typically Lingula facies & \\
\hline & & $\begin{array}{l}\text { Cancelloceras } \\
\text { cumbriense }\end{array}$ & G1b1 & $\begin{array}{l}\text { Ca. cumbriense } \\
a \& b\end{array}$ & $\begin{array}{l}\text { Gastrioceras } \\
\text { cumbriense }\end{array}$ & $\begin{array}{l}\text { B. superbilinguis, Cancelloceras } \\
\text { sp., Ca. crenulatum, } \\
\text { Gastrioceras carbonarium, G. } \\
\text { listeri, Homoceratoides sp., } \\
\text { Hm.divaricatus, }\end{array}$ & \\
\hline & \multirow[b]{2}{*}{ G1a } & & & & & $\begin{array}{l}\text { Owd Betts Marine Band- anoxic } \\
\text { event lacking marine fauna }\end{array}$ & \\
\hline & & $\begin{array}{l}\text { Cancelloceras } \\
\text { cancellatum }\end{array}$ & G1a1 & $\begin{array}{l}\text { Ca. cancellatum } \\
a, b \& c\end{array}$ & $\begin{array}{l}\text { Gastrioceras } \\
\text { cancellatum }\end{array}$ & $\begin{array}{l}\text { Agastrioceras carinatum, } B . \\
\text { superbilinguis, Cancelloceras } \\
\text { sp., Ca. branneroides, Ca. } \\
\text { crencellatum, Ca. crenulatum, } \\
\text { Ca. cumbriense Ca. Rurae, } \\
\text { Homoceratoides } \mathrm{sp} ., \\
\text { Hm..divaricatus }\end{array}$ & \\
\hline \multirow{8}{*}{ 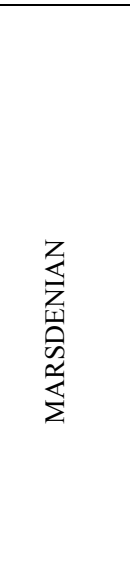 } & \multirow[t]{2}{*}{$\mathrm{R} 2 \mathrm{c}$} & \multirow[t]{2}{*}{$\begin{array}{l}\text { Bilinguites } \\
\text { superbilinguis }\end{array}$} & $\mathrm{R} 2 \mathrm{c} 2$ & Verneulites sigma & $\begin{array}{l}\text { Donetzooceras } \\
\text { (Gastrioceras) sigma }\end{array}$ & $\begin{array}{l}\text { B. superbilinguis, Ca. } \\
\text { cumbriense, Gastrioceras sp., } \\
\text { Ca. crenulatum, } \\
\text { Homoceratoides sp., , }\end{array}$ & \multirow[t]{2}{*}{ N10 } \\
\hline & & & $\mathrm{R} 2 \mathrm{c} 1$ & B. superbilinguis & $\begin{array}{l}\text { R. superbilingue, } R \text {. } \\
\text { reticulatum mut. } \gamma,\end{array}$ & $\begin{array}{l}\text { Gastrioceras sp., G. lineatum, } \\
\text { Homoceratoides sp. } \\
\text { Hm..divaricatus, Hm. } \\
\text { fortelirifer, Verneulites sigma }\end{array}$ & \\
\hline & \multirow[t]{5}{*}{$\mathrm{R} 2 \mathrm{~b}$} & \multirow{5}{*}{$\begin{array}{l}\text { Bilinguites } \\
\text { bilinguis }\end{array}$} & R2b5 & B. metabilinguis & R. bilingue late mut. $\beta$ & $\begin{array}{l}\text { Bilinguites sp., B. bilinguis, } B . \\
\text { eometabilinguis, Verneulites } \\
\text { sigma }\end{array}$ & \multirow{6}{*}{ N9 } \\
\hline & & & $\mathrm{R} 2 \mathrm{~b} 4$ & B. eometabilinguis & R. bilingue late mut. $\beta$ & B. bilinguis & \\
\hline & & & R2b3 & B. bilinguis & R. bilingue mut. $\beta$ & \multirow{3}{*}{$\begin{array}{l}\text { Bilinguites sp., } R . \\
\text { circumplicatile }\end{array}$} & \\
\hline & & & $\mathrm{R} 2 \mathrm{~b} 2$ & B. bilinguis & R. bilingue mut. $\beta$ & & \\
\hline & & & R2b1 & B. bilinguis & R. bilingue early mut. $\beta$ & & \\
\hline & $\mathrm{R} 2 \mathrm{a}$ & $\begin{array}{l}\text { Bilinguites } \\
\text { gracilis }\end{array}$ & R2a1 & $\begin{array}{l}\text { B. gracilis } \\
a, b \& c\end{array}$ & $\begin{array}{l}\text { R. gracile, } R \text {. } \\
\text { reticulatum mut. } \alpha\end{array}$ & $\begin{array}{l}\text { Bilinguites sp., } R \text {. reticulatum, } \\
R \text {. gracilingue, } R \text {. graciloides }\end{array}$ & \\
\hline \multirow{13}{*}{ 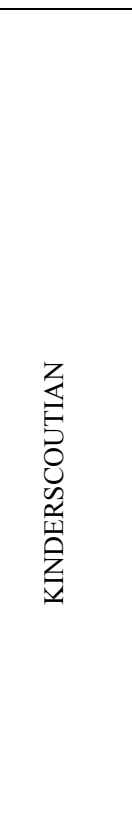 } & \multirow{5}{*}{$\mathrm{R} 1 \mathrm{c}$} & \multirow{5}{*}{$\begin{array}{l}\text { Reticuloceras } \\
\text { reticulatum }\end{array}$} & R1c5 & & & Butterly MB- Lingula & \multirow{5}{*}{ N8 } \\
\hline & & & $\mathrm{R} 1 \mathrm{c} 4$ & R. coreticulatum & & $\begin{array}{l}\text { Anthracoceratites sp., } \\
\text { Homoceratoides divaricatus, } \\
\text { Hudsonoceras ornatum, } R \text {. } \\
\text { reticulatum (late form), } V . \\
\text { striolatus }\end{array}$ & \\
\hline & & & R1c3 & R. reticulatum & & \multirow{3}{*}{$\begin{array}{l}\text { Homoceratoides prereticulatus, } \\
\text { R. davisi, } R \text {. regularum, Vallites } \\
\text { sp., V. striolatus }\end{array}$} & \\
\hline & & & R1c2 & R. reticulatum & & & \\
\hline & & & R1c1 & R. reticulatum & & & \\
\hline & \multirow[t]{3}{*}{$\mathrm{R} 1 \mathrm{~b}$} & \multirow[t]{3}{*}{$\begin{array}{l}\text { Reticuloceras } \\
\text { eoreticulatum }\end{array}$} & R1b3 & R. stubblefieldi & $\begin{array}{l}\text { Eumorphoceras } \\
\text { stubblefieldi }\end{array}$ & $\begin{array}{l}\text { Vallites striolatus, } \\
\text { Hudsonoceras ornatum, } R \text {. } \\
\text { Moorei, } R \text {. regularum }\end{array}$ & \multirow{3}{*}{ N7 } \\
\hline & & & R1b2 & R. nodosum & & $\begin{array}{l}\text { Homoceras spiraloides, Vallites } \\
\text { striolatus }\end{array}$ & \\
\hline & & & R1b1 & R. eoreticulatum & & Reticuloceras sp. & \\
\hline & \multirow{5}{*}{ R1a } & & R1a5 & R. dubium & & Reticuloceras sp., R. adpressum & \multirow{7}{*}{ N6 } \\
\hline & & $\begin{array}{l}\text { Hodsonites } \\
\text { magistrorum }\end{array}$ & R1a4 & R. todmordenense & & $\begin{array}{l}\text { Homoceras sp., Reticuloceras } \\
\text { sp., R. paucicrenulatum, } R \text {. } \\
\text { adpressum }\end{array}$ & \\
\hline & & & R1a3 & R. subreticulatum & & $\begin{array}{l}\text { Homoceratoides sp., } \\
\text { Reticulatum pulchellum }\end{array}$ & \\
\hline & & & R1a2 & R. circumplicatile & & $\begin{array}{l}\text { Homoceratoides sp. Vallites } \\
\text { (Homoceras) henkei, }\end{array}$ & \\
\hline & & & R1a1 & Ho. magistrorum & & R. compressum & \\
\hline & $\mathrm{H} 2 \mathrm{c}$ & Vallites & $\mathrm{H} 2 \mathrm{c} 2$ & $\begin{array}{l}\text { Homoceratoides } \\
\text { prereticulatus }\end{array}$ & Hm. prereticulatum & Homoceras sp. & \\
\hline 文 & & eostriolatus & $\mathrm{H} 2 \mathrm{c} 1$ & V. eostriolatus & $\begin{array}{l}\text { Homoceras } \\
\text { eostriolatum }\end{array}$ & Ho. undulatum & \\
\hline 产 & $\mathrm{H} 2 \mathrm{~b}$ & $\begin{array}{l}\text { Homoceras } \\
\text { undulatum }\end{array}$ & $\mathrm{H} 2 \mathrm{~b} 1$ & Ho. undulatum & & Ho. beyrichianum, Ho. smithii & N5 \\
\hline$\overline{4}$ & $\mathrm{H} 2 \mathrm{a}$ & $\begin{array}{l}\text { Hudsonoceras } \\
\text { proteum }\end{array}$ & $\mathrm{H} 2 \mathrm{a} 1$ & $\begin{array}{l}\text { Hd. proteum } \\
a, b \& c\end{array}$ & Hd.proteus & Homoceras smithii & \\
\hline z & $\mathrm{H} 1 \mathrm{~b}$ & Homoceras & H1b2 & $\begin{array}{l}\text { Isohomoceras. sp. } \\
\text { nov. }\end{array}$ & & Homoceras sp. & \\
\hline 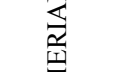 & & beyrichianum & $\begin{array}{l}\text { H1b1 } \\
\mathrm{a} \& \mathrm{~b}\end{array}$ & H. beyrichianum & & $\begin{array}{l}\text { Ho. diadema, Ho. subglobosum, } \\
\text { Isohomoceras } \mathrm{sp} .\end{array}$ & \\
\hline$\vec{z}$ & & & H1a3 & I. subglobosum & Homoceras & & N4 \\
\hline 总 & H1a & Isohomoceras & $\mathrm{H} 1 \mathrm{a} 2$ & I. subglobosum & subglobosum & & \\
\hline & & subglobosum & H1a1 & I. subglobosum & & & \\
\hline
\end{tabular}




\begin{tabular}{|c|c|c|c|c|c|c|c|}
\hline Substages & Index & Ammonoid & Index & Diagnostic ammonoid & Former name & Associated ammonoids & $\begin{array}{l}\text { 'Meso- } \\
\text { thems' }\end{array}$ \\
\hline \multicolumn{7}{|c|}{ SERPUKHOVIAN STAGE (NAMURIAN REGIONAL STAGE) } & \multirow{4}{*}{ N3 } \\
\hline \multirow{12}{*}{ 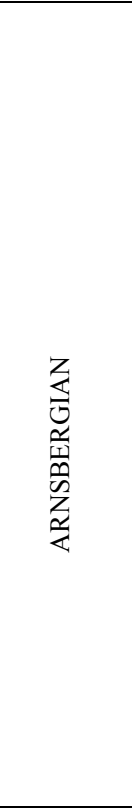 } & \multirow{4}{*}{$\mathrm{E} 2 \mathrm{c}$} & \multirow{4}{*}{$\begin{array}{l}\text { Nuculoceras } \\
\text { stellarum }\end{array}$} & E2c4 & N. nuculum & & \multirow{3}{*}{$\begin{array}{l}\text { C. darwenense, Ct. fragile, } E \text {. } \\
\text { bisulcatum, } \\
\text { Kazakhoceras hawkinsi }\end{array}$} & \\
\hline & & & E2c3 & N. nuculum & & & \\
\hline & & & $\mathrm{E} 2 \mathrm{c} 2$ & N. nuculum & & & \\
\hline & & & $\mathrm{E} 2 \mathrm{c} 1$ & N. stellarum & $\begin{array}{l}\text { Cravenoceratoides } \\
\text { stellarum }\end{array}$ & Fayettevillea holmesi, & \multirow{4}{*}{ N 2} \\
\hline & \multirow{3}{*}{$\mathrm{E} 2 \mathrm{~b}$} & \multirow{3}{*}{$\begin{array}{l}\text { Cravenocera- } \\
\text { toides } \\
\text { edalensis }\end{array}$} & E2b3 & Ct. nititoides & & $\begin{array}{l}\text { Cravenoceras sp., Eumorphoceras } \\
\text { rostratum }\end{array}$ & \\
\hline & & & $\begin{array}{l}\text { E2b2 } \\
a-c\end{array}$ & Ct. nitidus & Ct. nitidum & $\begin{array}{l}\text { Cravenoceras sp., C. subplicatum, } \\
\text { Cravenoceratoides sp., } \\
\text { Eumorphoceras } \text { sp., E. bisulcatum, } \\
\text { E. leitrimense, Fayettevillea } \\
\text { holmesi, Glaphyrites sp., Gl. } \\
\text { Kettlesingense, }\end{array}$ & \\
\hline & & & $\begin{array}{l}\text { E2b1 } \\
\text { a-c }\end{array}$ & Ct. edalensis & & $\begin{array}{l}\text { Cravenoceras sp., C. subplicatum, } \\
\text { Fayettevillea cf. holmesi }\end{array}$ & \\
\hline & \multirow{5}{*}{$\mathrm{E} 2 \mathrm{a}$} & \multirow{5}{*}{$\begin{array}{l}\text { Cravenoceras } \\
\text { cowlingense }\end{array}$} & E2a3 & Eumorphoceras yatesae & & $\begin{array}{l}\text { Cravenoceras sp., C. gairense, } \\
\text { Eumorphoceras sp. }\end{array}$ & \multirow{9}{*}{ N 1} \\
\hline & & & $\mathrm{E} 2 \mathrm{a} 2 \beta$ & Anthracoceras & & Saleswheel Marine Band & \\
\hline & & & $\mathrm{E} 2 \mathrm{a} 2 \alpha$ & C. gressinghamense & & $\begin{array}{l}\text { C. cf. gairense, Eumorphoceras } \\
\text { sp., }\end{array}$ & \\
\hline & & & $\mathrm{E} 2 \mathrm{a} 2$ & $\begin{array}{l}\text { Eumorphoceras } \\
\text { ferrimontanum }\end{array}$ & $\begin{array}{l}\text { Eumorphoceras } \\
\text { bisulcatum }\end{array}$ & $\begin{array}{l}\text { Cravenoceras sp., C. gairense, E. } \\
\text { erinense, Kazakhoceras scaliger }\end{array}$ & \\
\hline & & & $\begin{array}{l}\text { E2a1 } \\
\mathrm{a}-\mathrm{c}\end{array}$ & C. cowlingense & $\begin{array}{l}\text { Eumorphoceras } \\
\text { bisulcatum }\end{array}$ & $\begin{array}{l}\text { Cravenoceras sp., E. } \\
\text { grassingtonense }\end{array}$ & \\
\hline \multirow{4}{*}{ 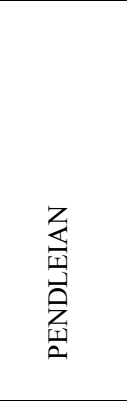 } & \multirow[b]{2}{*}{ E1c } & \multirow{2}{*}{$\begin{array}{l}\text { Cravenoceras } \\
\text { malhamense }\end{array}$} & E1c2 & & & Blacko Marine Band- Sanguinolites & \\
\hline & & & E1c1 & C. malhamense & & $\begin{array}{l}\text { Cravenoceras sp., Eumorphoceras } \\
\text { sp. }\end{array}$ & \\
\hline & \multirow[t]{2}{*}{ E1b } & \multirow[t]{2}{*}{$\begin{array}{l}\text { Cravenoceras } \\
\text { brandoni }\end{array}$} & $\begin{array}{l}\text { E1b2 } \\
\mathrm{a} \& \mathrm{~b}\end{array}$ & $\begin{array}{l}\text { Tumulites } \\
\text { pseudobilinguis }\end{array}$ & $\begin{array}{l}\text { Eumorphoceras } \\
\text { pseudobilingue }\end{array}$ & $\begin{array}{l}\text { Edmooroceras angustum, Ed. } \\
\text { hudsoni, Ed. stubblefieldi, } \\
\text { Eumorphoceras sp., Tumulites sp, }\end{array}$ & \\
\hline & & & E1b1 & C. brandoni & & Edmooroceras stubblefieldi & \\
\hline
\end{tabular}

Table 2. Ammonoid zones and subzones of the Namurian regional stage with diagnostic ammonoids and indices mainly from Riley et al. (1995). 'Mesothem' nomenclature is that of Ramsbottom (1977). Former names and a compilation of ammonoid assemblages for each marine band were used when studying sample collections and literature reviews to determine the extent of ammonoid facies within specific marine bands. a) Serpukhovian international stage; b) Bashkirian international stage (part). 
Table 3. Marine bands of the Westphalian regional stage with diagnostic ammonoids or acme facies, mainly from Waters et al. (2011). 'Mesothem' nomenclature is that of Ramsbottom (1979). Former names and a compilation of ammonoid assemblages for each marine band were used when studying sample collections and literature reviews to determine the extent of ammonoid facies within specific marine bands.

\begin{tabular}{|c|c|c|c|c|c|c|}
\hline \multirow[b]{2}{*}{ 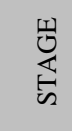 } & \multirow{2}{*}{$\begin{array}{l}\text { REGIONAL } \\
\text { SUB- } \\
\text { STAGES }\end{array}$} & \multicolumn{4}{|c|}{ WESTERN EUROPEAN MARINE BANDS } & \multirow[b]{2}{*}{ 它 } \\
\hline & & $\begin{array}{l}\text { MARINE BAND } \\
\text { NAME }\end{array}$ & $\begin{array}{l}\text { Diagnostic ammonoid or } \\
\text { acme facies }\end{array}$ & Former name & Associated ammonoids & \\
\hline \multirow{10}{*}{ 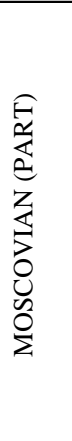 } & \multirow{6}{*}{$\begin{array}{l}Z \\
\longleftarrow \\
0 \\
0 \\
0 \\
0 \\
0\end{array}$} & Cambriense & Donetzoceras cambriense & Top & & \multirow{3}{*}{ W10 } \\
\hline & & Shafton & Anthracoceras hindi & & & \\
\hline & & Main Estheria & Estheria & & & \\
\hline & & Edmondia & foraminifera & & & W9 \\
\hline & & Carway Fawr & foraminifera & & Proved in S. Wales only & \multirow{3}{*}{ W8 } \\
\hline & & Aegiranum & Donetzoceras aegiranum & Mansfield & $\begin{array}{l}\text { Anthracoceras hindi, } \\
\text { Gastrioceras sp., G. } \\
\text { depressum, } \\
\text { Homoceratoides politus } \\
\end{array}$ & \\
\hline & \multirow{7}{*}{ 觉荎 } & Sutton & Lingula & & & \\
\hline & & Haughton & Levipustula & & & \multirow[b]{3}{*}{ W7 } \\
\hline & & Clown & Lingula & & & \\
\hline & & Manton Estheria & Estheria & & & \\
\hline \multirow{14}{*}{ 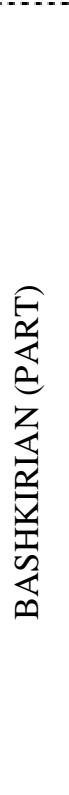 } & & Maltby & Myalina & Two Foot & & \\
\hline & & Lowton Estheria & Estheria & & & W6 \\
\hline & & Vanderbeckei & Anthracoceras vanderbeckei & Clay Cross & & \\
\hline & \multirow{11}{*}{ 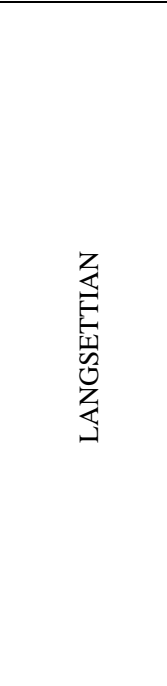 } & Low Estheria & Estheria & & & W5 \\
\hline & & Burton Joyce & Caneyella, Posidonia & & & \multirow{2}{*}{ W4 } \\
\hline & & Langley & Lingula & Upper Band & & \\
\hline & & Amaliae & Gastrioceras amaliae & Norton (Tonge's) & & \multirow{3}{*}{ W3 } \\
\hline & & Meadow Farm & Dunbarella, Posidonia & Forty Yard & & \\
\hline & & Parkhouse & Lingula, Caneyella & & & \\
\hline & & Listeri & Gastrioceras listeri & Alton & $\begin{array}{l}\text { G. circumnodosum, G. } \\
\text { coronatum, G. retrorsum, } \\
\text { Homoceratoides } \\
\text { divaricatus }\end{array}$ & \multirow[t]{4}{*}{ W2 } \\
\hline & & Honley & Gastrioceras sp. & First Smalley & & \\
\hline & & Springwood & Lingula & Second Smalley & & \\
\hline & & Holbrook & Lingula & Lower Bassey & & \\
\hline & & Subcrenatum & Gastrioceras subcrenatum & Pot Clay & $\begin{array}{l}\text { Gastrioceras sp., G. } \\
\text { carbonarium, G. listeri, G. } \\
\text { retrorsum, } \\
\text { Homoceratoides sp., H. } \\
\text { divaricatus, Reticuloceras } \\
\text { superbilingue }\end{array}$ & $\begin{array}{l}\text { W1/ } \\
\text { N11 }\end{array}$ \\
\hline
\end{tabular}

